


\section{관광두레 법제화 방안 연구}

A Study on the Legalization of Tourdure

박주영 

연구책임

박주영 한국문화관광연구원 연구위원

공동연구

진보라 한국문화관광연구원 부연구위원 

관광두레 법제화 방안 연구

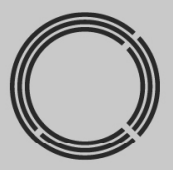

연구개요 



\section{1. 서론}

\section{가. 연구 배경 및 목적}

- 관광두레사업은 2013년부터 시행한 문화체육관광부의 정책 사업으로서, 주민 공동체가 지역자원을 활용한 다양한 관광 사업을 경영하고, 관광객이 이러한 상품을 소비함으로써 지역 내에 관광객의 소비가 순환해 지역경제가 활성화 되는 것을 목표로 함. 2019년까지 480개 주민공동체를 발굴·육성하였고, 2019년 관광두레사업을 통한 일자리 수는 850명으로 집계되는 등 관광두레 사업이 지역 내 일자리 창출 및 경제 활성화 효과를 견인하는 것으로 평가됨 (문화체육관광부, 2020)

- 문재인 정부의 국정과제에 “관광을 통한 지역 균형발전과 지역경제 활성화”를 위해 관광두레 주민공동체를 2022년까지 1,125 개 발굴하는 것으로 상정되었 고, 이를 토대로 관광두레사업의 예산 및 대상지역 규모가 계속 확대되는 등 관광두레사업의 성과를 지속적으로 창출하기 위한 방안 모색이 필요한 시점임

- 지금까지 관광두레사업은 「관광진흥법」제 47 조의 7 과 제 48 조에 근거하여 추 진되었으나 직접적인 근거 법령 부재로 인해 중앙과 지방자치단체를 비롯해 지역 내 다양한 조직, 주체들 간 유기적 협력 체계를 갖추는 데 어려움을 겪음. 특히 지방자치단체는 사업에 대한 직접적인 근거 법령 부재로 주민사업체와 관광두레 $\mathrm{PD}$ 의 지원 방안을 마련하기 어려운 상황임

- 이와 같이 사업 추진 현장에서 발생하는 애로사항뿐 아니라 사업의 안정적 확 대와 발전을 위한 추진 체계 구축을 위해 법제화 필요성이 지속적으로 제기되 어 왔으나 실체적 구현을 위한 법제화 연구와 노력은 이루어지지 않음. 그동안 관광두레사업은 지역관광의 새로운 발전 모델을 지향하고 사업 내용과 방식을 개선·발전시켜 온 바, 고유의 특성을 살려 당초 목적대로 사업이 안정적·체계 적으로 추진되기 위해서는 법적 기반을 마련할 필요가 있음

- 이에 본 연구는 관광두레사업의 직접적인 근거 법령을 마련하여 주민주도의 지역 관광 활성화를 유도하고 문화체육관광부 장관과 지방자치단체 장이 주민주도형 관 광 사업을 추진할 수 있도록 근거 규정을 만들어 지원 체계를 공고히 하고자 함 


\section{나. 연구 범위 및 체계}

- (시간적 범위) 관광두레사업의 사업기간을 고려해 2013년 7월부터 2020년 4월까지를 시간적 범위로 함

- (공간적 범위) 관광두레사업은 기초지방자치단체를 대상으로 매년 공모를 통 해 신규 사업대상지역을 선정하기 때문에 관광두레사업 대상지역으로 선정된 기초지방자치단체를 공간적 범위로 함

- (내용적 범위) 연구 논리에 따라 크게 네 가지로 구분함. 1) 관광두레사업 추진 성과와 한계, 2) 관광두레사업 관련 법령 및 유사 사례 분석, 3) 관광두레사업 법제화 방안, 4) 결론 및 제언

- (연구 방법) 본 연구 수행을 위해 1) 문헌연구 및 2차 자료 분석, 2) 법령 조사. 연구, 3) 이해관계자 심층인터뷰, 4) 전문가 회의 및 자문 등의 방법을 적용함

[그림 1] 연구 수행 체계
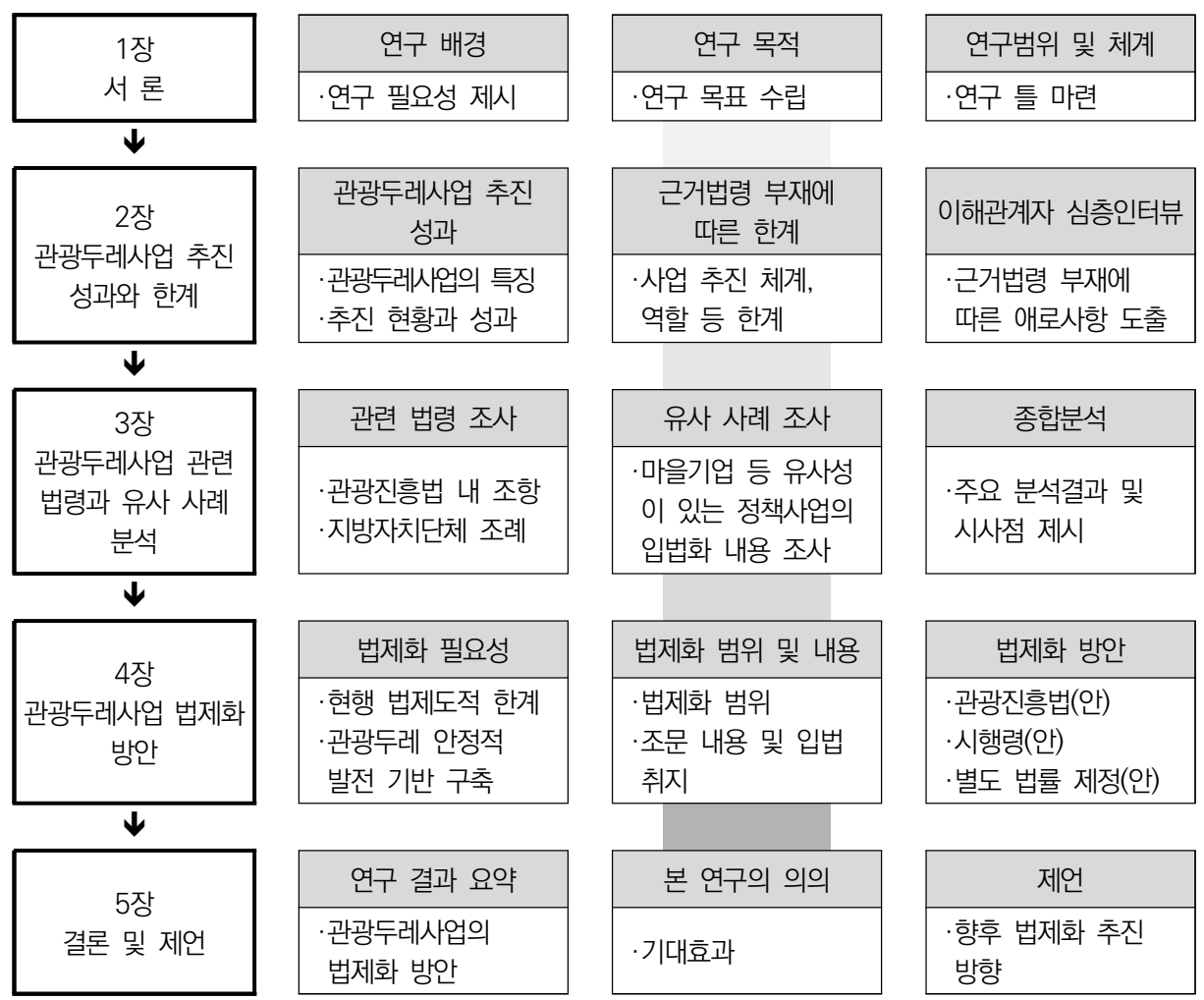


\section{2. 관광두레사업 추진 성과와 한계}

\section{가. 관광두레사업의 추진 성과}

1) 관광두레사업 추진 배경 및 목적

- 지역을 방문하는 관광객 수를 늘리는 것 보다 관광객들의 소비가 지역 내 순 환되어 일자리 증가와 주민 소득 창출 등 긍정적인 효과로 이어지도록 하는 게 중요하다고 인식함. 시설 조성보다 지역 내 여러 자원을 엮어 효과적으로 경영하도록 할 것인가, 주민들이 다양한 관광 사업을 창출할 수 있도록 할 것 인가에 대해 관심을 둠

- 또한 관광으로 인한 편익과 성과가 지역사회에 확산되고 관광을 통한 발전이 이루어져야 관광이 지속가능함을 고려함. 이에 관광두레사업은 지역관광 정책 의 패러다임을 '비즈니스 창출' 중심으로 바꾸고, '지속가능한 관광'을 실천할 해법으로서, 지역주민 공동체를 관광사업 주체로 육성하는 지원 체계를 제시 함(문화체육관광부, 한국문화관광연구원, 2020)

- 관광두레사업의 목적

- (주민 주도의 관광사업체 창업 및 육성 지원) 지역주민이 주도·협력하여 지 역을 방문하는 관광객을 대상으로 숙박, 식음, 주민여행, 체험, 기념품 등의 관광 사업을 경영하는 관광사업체를 성공 창업하고 자립 발전하도록 지원함 - (관광두레 형성을 통한 공동체 의식 제고 및 지역관광 활성화) 주민이 경영 하는 관광사업체 간 두레(네트워크)를 형성하여 공동체 의식을 함양하고 경 쟁력을 높임으로써 지속 성장을 유도함

- '관광두레'란 주민의 자발적 참여와 지역자원의 연계·활용을 통한 새로운 방 식의 지역관광발전 모델을 의미하고, '관광두레 주민사업체'는 관광두레 사업 대상지역(시·군·구)에서 발굴·육성하는 관광사업 주민공동체를 의미함 


\section{2) 관광두레사업 추진 체계}

- 관광두레사업은 문화체육관광부, 총괄지원기관(한국문화관광연구원, 한국관 광공사) 1 , 지방자치단체(사업 대상지역), 관광두레프로듀서(이하, 관광두레 $\mathrm{PD})$, 전문가(멘토), 지역주민 등의 협력을 기초로 함

- 사업 추진체계에서 다른 정책사업과 달리 문화체육관광부의 재정이 지방자치 단체를 거치지 않고, 총괄지원기관이 관광두레PD 활동비와 지역주민 역량 강 화 비용을 지원한다는 데 특징이 있음

- 또한 관광두레 $\mathrm{PD}$ 는 관광두레사업의 주요 특징이자 핵심 주체임. 지역주민을 대상으로 단계별·맞춤형 현장 밀착 지원을 함으로써 주민사업체 육성 지원이 종료된 뒤에도 해당 사업체가 자생력을 갖고 지속 경영을 할 수 있도록 하는 데에 관광두레PD가 주요한 역할을 함

〈표 1〉 관광두레사업 추진 주체별 역할

\begin{tabular}{|c|c|c|}
\hline \multicolumn{2}{|c|}{ 주체 } & 역할 \\
\hline \multicolumn{2}{|c|}{ 문화체육관광부 } & - 기본계획 수립, 재정 지원 \\
\hline \multirow{2}{*}{$\begin{array}{c}\text { 총괄 } \\
\text { 지원기관 }\end{array}$} & $\begin{array}{c}\text { 한국문화 } \\
\text { 관광연구원 }\end{array}$ & $\begin{array}{l}\text { - 관광두레PD 활동 지원과 관리, 주민공동체 발굴과 육성(사업화 계획 수립 지원, } \\
\text { 멘토링, 역량 강화, 창업과 경영개선 파일럿사업 지원 등), 사업 모니터링, 평가, } \\
\text { 홍보·마케팅 등 사업 추진 총괄 }\end{array}$ \\
\hline & $\begin{array}{l}\text { 한국관광 } \\
\text { 공사 }\end{array}$ & - 홍보·마케팅 \\
\hline \multicolumn{2}{|c|}{ 지방자치단체 } & - 관광두레 사랑방 제공, 주민사업체 발굴 지원, 지역자원 연계 지원 등 \\
\hline \multicolumn{2}{|c|}{ 관광두레PD } & $\begin{array}{l}\text { - 관광두레사업 추진 주체들 사이에서 중간 지원 역할을 하는 기획자, 활동가 } \\
\text { - 주민공동체를 발굴하여 사업화 계획을 수립하고 주민사업체로서 법인격을 갖춰 } \\
\text { 창업에 이르는 전 과정을 밀착 지원 }\end{array}$ \\
\hline \multicolumn{2}{|c|}{ 전문가(멘토) } & $\begin{array}{l}\text { - 지역주민들이 관광 수요에 부합하며 지역자원을 활용해 매력적인 관광 상품과 } \\
\text { 서비스를 개발할 수 있도록 주민 역량 강화 지원 }\end{array}$ \\
\hline \multicolumn{2}{|c|}{ 지역주민 } & $\begin{array}{l}\text { - 관광두레사업의 실질적 주체 } \\
\text { - 관광두레사업 참여를 통해 주민사업체를 창업 또는 경영 개선 }\end{array}$ \\
\hline
\end{tabular}

1) 2013년 관광두레사업부터 2019년 관광두레사업까지는 한국문화관광연구원이 관광두레사업의 총괄 운영 을 담당하고, 한국관광공사는 홍보·마케팅 지원만 담당하였으나, 2020년 관광두레사업부터 한국관광공사 가 사업 전체를 총괄 지원함 


\section{3) 관광두레사업 내용 및 추진 현황}

- 관광두레사업 대상지역으로 선정되면 연차별 목표에 따라 기본적으로 3년 간 사 업이 추진됨. 종합평가를 통해 관광두레사업 우수 모델로 성장 가능성이 있는 지 역을 선정하여 2년을 추가 지원하기 때문에 지원 기간은 기본 3년, 최대 5년임

- 다만 매년 말 평가를 통해 사업 계속 추진 지역과 당해 년 완료 지역을 결정 함. 연 단위로 지역별 사업 평가에 따라 계속 추진의 타당성이 낮으면 해당 지역의 사업이 종료됨

- 관광두레사업 내용은 크게 1) 관광두레PD 선발과 역량 강화, 2) 주민사업체 발굴과 사업 계획 수립 지원, 3) 주민사업체 창업과 경영 개선 지원, 4) 연계 통합 프로그램 운영, 5) 홍보·마케팅으로 구분됨

- 관광두레사업의 연도별 추진 실적은〈표 2〉와 같음

〈표 2〉 관광두레사업 연도별 추진 실적

\begin{tabular}{|c|c|c|c|c|c|c|c|c|}
\hline 구분 & 2013년 & 2014년 & 2015년 & 2016년 & 2017년 & 2018년 & 2019년 & 합계 \\
\hline 사업비 & 시범 & 20억 & 30억 & 40억 & 40억 & 60억 & 80억 & 270 억 \\
\hline 신규 사업대상지역 & 5개 & 20개 & 11개 & 8개 & 7개 & 10개 & 12개 & 73개 \\
\hline 신규 주민사업체 발굴 & 36개 & 105개 & 59개 & 51개 & 48개 & 68개 & 113개 & 480개 \\
\hline $\begin{array}{c}\text { 신규 관광두레PD } \\
\text { (청년PD포함) }\end{array}$ & 6명 & 26명 & 14명 & 11명 & 7명 & 18명 & 20명 & 102명 \\
\hline
\end{tabular}

주 : 관광두레PD는 2016년까지 팀(2인)으로도 선발하다 2017년부터 1인 선발, 2018년부터 청년PD 선발

- 관광두레사업은 매년 문화체육관광부와 총괄지원기관이 수립한 계획에 따른 “관광두레사업지침”을 근거로 추진되었으며 중요한 체계상 변화는 다음과 같음

- 관광두레사업 추진 체계에 있어서 주요 변화는 2018년 청년PD의 선발과 광 역관광두레협력센터의 신설임. 2018년은 관광두레사업이 시작된 지 6년 차로 2013년 선정된 관광두레사업 대상지역에 대한 지원이 2017년에 완료됨

- 2018년부터 청년PD를 선정하여, PD와 청년PD 2인이 협력하여 활동할 수 있는 체계가 마련되었고 2019년부터 관광두레 지역협력사업의 일환으로 광역관광두레협력센터를 구성·운영 중임 


\section{4) 관광두레사업 성과}

(1) 주민주도의 관광사업 모델 개발

- 관광두레사업은 주민들이 공동체를 구성하여 자발성과 협력성을 가지고 지역관 광 혹은 지역의 문제를 스스로 해결하도록 지원함

- 2019년까지 관광두레사업 지원을 토대로 창업 및 경영 개선을 완료한 주민사 업체는 110 개임. 지역에 대해 잘 알고 있는 지역주민들은 서툴지만 진심이 담 긴 관광상품과 서비스를 제공하기 때문에, 관광객들은 새로운 경험과 만족을 느끼게 됨

- 식음 분야의 주요 사례로 여수 수레인보우 협동조합, 춘천 더티파머스가 있음

- 숙박 분야의 주요 사례로 안동 서로가협동조합, 춘천 쟁강협동조합이 있음 - 주민여행사 분야의 주요 사례로 시흥 협동조합공정여행동네, 홍성 주식회사 행복한여행나눔이 있음

- 기념품 분야의 주요 시례로 곡성 수상한영농조합법인, 담양 담양대나무공예인 협동조합이 있으며 체험 분야의 주요 시례로 양평 양평수상안전교육원이 있음

(2) 지역경제 활성화 효과 도출

- 2019년 주민사업체 연간 매출액은 83억4천만 원(850명 일자리 창출)이며, 누적 매출액은 426억4천만 원임. 2019년까지 관광두레사업에 투입한 사업비 270 억 원과 관광두레사업으로 육성한 주민사업체가 창출한 매출액만 단순 비 교해도 약 1.6 배에 달함

- 지역자원을 활용하여 지역 내 관광소비가 순환된다는 점을 고려하면, 관광두레 주 민사업체의 상품과 서비스에 대한 전후방 경제적 파급 효과는 더욱 큼

(3) 지역관광 주체 육성

- 2013년부터 2019년까지 102명의 관광두레PD가 선발되어, PD 활동기간 동 안 다양한 역량 강화 과정을 거침. $\mathrm{PD}$ 활동 종료 후에도 지역 내에서 다양한 활동을 지속함으로써 지역 발전에 기여할 수 있는 기반을 마련함 
- 2019년까지 매년 1,200 여 명의 주민이 관광두레사업에 참여하였으며 주민들 은 지역관광 혹은 지역 문제를 관광 사업으로 해결하고자 창업 또는 경영개선에 필요한 역량을 쌓음. 창업과 경영개선을 완료한 주민사업체는 지역관광 상품과 서비스를 생산·판매하는 실질적 주체가 됨. 창업과 경영개선을 완료하지 못한 주민들도 관광두레사업에 참여함으로써 지역관광의 문제를 고민하고, 문제를 해결하기 위한 역량을 강화했기 때문에 잠재적 관광 주체가 되었다고 평가됨

- 주민여행사 시례로 소개한 (주)행복한여행나눔은 문화체육관광부가 추진하는 '지역 관광추진조직(DMO: Destination Management/Marketing Organization)' 육성지원 공모사업에 선정되어 홍성군 관광 관련 기업과 협회, 주민조직과 협력 연계망을 구축하고 관광 콘텐츠를 기획하는 등 한 단계 더 발전한 모습을 보임

(4) 지역주민들의 인식 변화

- 관광두레사업을 통해 단계별로 지원을 받아 주민사업체를 창업한 주민들은 '우 리도 할 수 있다'는 자신감뿐 아니라 '공동체', '협력'이라는 가치가 더해지면 더 욱 경쟁력을 갖춘 관광 상품을 만들어 낼 수 있음을 인지하게 됨(박주영, 2020)

- 2019년 주민 대상 설문조사 결과에 따르면, 관광두레사업을 통해 '공동체 의식 향상(전년 대비 5.2\%p 증가)', '자발성과 주민의식 향상(전년 대비 $4.9 \% \mathrm{p}$ 증가)', '지역관광 활성화(전년 대비 $4.3 \% \mathrm{p}$ 증가)', '공동 목표 달성을 위한 협력 강화(전 년 대비 $4.0 \% \mathrm{p}$ 증가)', '지역 경제 순환(전년 대비 $2.8 \% \mathrm{p}$ 증가)'으로 나타났고 관광두레사업으로 인한 긍정적 변화에 대한 인식이 80점 이상으로 나타남

(5) 정책 패러다임 변화 선도

- 관광두레사업의 시작을 계기로 관광산업의 공급자(사업체, 인프라) 및 소비자(관 광객) 중심의 관광정책 속에서 방관자로 인식되었던 지역주민들이 생산자 및 소비 자이며, 정책의 주체로서 인식하는 관광정책으로 전환됨(문화체육관광부, 2020)

- 관 주도형 하드웨어 중심의 지원보다 인재 육성과 주민 주도 역량 강화 등 소프트 웨어 중심의 지원이 지역 발전에 있어 더 긍정적 효과를 나타낸다는 것을 증명함 
- 관광두레 $\mathrm{PD}$ 를 통한 지역 현장 중심의 지원 방식이나, 관광두레 주민사업체 간의 협력을 통한 경쟁력 강화 방식 등이 타 부처 및 기관의 사업에 활용됨 - 관광두레사업의 특징과 강점을 착안하여 제주관광공사의 제주 삼촌PD, 산 림청의 산림일자리발전소, 환경부의 생태관광디렉터, 농림부의 주민주도 농 촌관광 콘텐츠 개발 사업 등이 추진됨

\section{나. 관광두레사업 한계}

1) 심층 조사 개요

- 목적 : 관광두레 근거 법 부재에 따른 애로사항, 법제화 필요성 등 의견 수렴

- 대상 : 관광두레 이해관계자 20명(관광두레PD 및 청년PD 11명, 광역관광두 레협력지원센터 3명, 주민사업체 2명, 지자체 담당자 4명)

- 조사 방법 : 구조화된 설문지 응답 및 인터뷰

\section{2) 추진 과정상의 한계점}

(1) (1차년) 관광두레 PD 선발

- 관광두레PD 역할 및 관광두레사업에 대한 이해 부족

- 관광두레PD 선정 시에는 지방자치단체에서 관련 지원을 약속하였으나, 담당공 무원 변경 및 법적 근거 부족으로 약속이 제대로 이행되지 않고 관심도가 낮음 - 지역 내·외 기관과 네트워크 구축 시, 관광두레 $\mathrm{PD}$ 를 중간지원주체로 인정해 주 지 않음. 아울러 중간지원주체로서 업무 범위나 권한 등에 대해 보장받지 못함

- 관광두레사랑방 지원 어려움

- 관광두레사랑방은 $\mathrm{PD}$ 근무공간이자 주민사업체 회의 및 교육, 관광두레사업 의 소통 창구 등의 공간임. 지방자치단체는 '관광두레사업 협력계획서'에 사 랑방 공간 마련에 대한 계획을 제시하였으나, 대상지역 선정 이후 법적 근거 부족으로 지원의 어려움을 토로함 
(2) (1 3차년) 주민사업체 육성

- 지방자치단체의 적극적 협력 유도 어려움

- 관광두레사업에 대한 지방자치단체 역할이 법적으로 명시되어 있지 않고 예산도 매칭하지 않다 보니, 지방지단체의 협력을 원활하게 이끄는 일은 관 광두레PD의 개인 역량과 관계의 문제로 맡겨짐

- 주민사업체에 대한 지원 근거 미비

- 관광두레 주민사업체는 창업 이전에는 공동체 조직이기 때문에, 지방자치단 체에서 예산을 지원할 근거가 없으며, 의회를 설득할 만한 근거도 부재함

- 관광두레사업은 소프트웨어 지원 중심이라 주민사업체가 창업 공간을 마련 하는 데 어려움이 있음. 하지만 지방자치단체 소유의 유휴공간을 관광두레 주민사업체에게 지원할 수 있는 법적 근거가 없음

(3) (4 5차년) 재정 지원 및 사후 관리

- 추가 2 년 지원 대상지역의 경우 5차년 예산 매칭 근거 미흡

- 관광두레사업은 3년 추진 후 종합평가를 통해 관광두레사업에 대한 계획과 의지를 평가하여 추가 2 년을 지원하지만 실제로 5 차년에 지방자치단체가 예산을 마련하는 데 대한 법적 근거가 부재함

- 중간지원조직의 원활한 운영 어려움

- 광역 시도에서 예산을 매칭하여 2019년부터 광역관광두레협력지원센터가 운영되고 있지만, 행정시스템과 지원방식이 불일치하고 중간지원조직에 대 한 지원 근거가 마련되지 않아 지속성을 담보하기 어려운 상황임

- 관광두레 주민사업체에 대한 지속적인 지원 및 관리 어려움

- 관광두레 주민사업체는 지원 완료 이후 지속적인 관리가 필요하고, 지역문 제 해결, 공동체 협력에 기초한 사업 구조 등 사회적 경제 조직의 성격과 특징을 가지고 있으나 사회적 경제 조직으로 인정되지 않아 여러 혜택에서 배제됨 


\section{2) 법제화 필요성에 대한 인식}

(1) 이해관계자들의 공감대

- 관광두레사업에 대한 직접적 근거 법령 부재에 따른 어려움 경험

- 관광두레사업 심층조사에 참여한 이해관계자 20 명 중 17 명이 사업을 수행 혹은 참여하면서 법적 근거 부재로 인해 어려움을 겪은 경험이 있다고 응답함

- 관광두레사업 법제화의 필요성에 대해 이해관계자 전원이 '매우 필요하다' 혹 은 '필요하다'고 응답하여, 공감 정도는 5점 만점에 4.8점을 기록함

- 이해관계자들은 관광두레 법제화 필요성으로 다음과 같은 사항을 제기함

- (지방자치단체 지원의 근거, 지방자치단체의 적극적 참여와 지원 의지 고취) 지방자치단체 담당자와 관광두레 $\mathrm{PD}$ 모두, 관광두레사업에서 지방자치단체의 협력이 대단히 중요하다고 인식하며 지방자치단체의 지원과 지역 간 편차를 없애기 위해서 법적 근거가 필요하다고 응답함

- (지역 관광자원 활용, 연계의 보장) 관광두레 주민사업체가 지역 내 관광지를 연계·활용해 관광 상품과 서비스를 제공함으로써 관광객 매력도와 만족도가 향상되지만, 지역 관광자원 활용 시 매번 담당부서 승인을 받아야 하기 때문 에 공공적 성격에 대한 명시가 필요함

- (지역주민, 전문가 등 관광두레사업 참여 활성화 기반) 관광두레사업 법적 근 거가 마련될 경우, 지역주민뿐 아니라 관광두레사업에 참여하는 관계자들의 사업에 대한 애착심과 자긍심, 책임감 등이 높아질 것으로 응답함

- (주민사업체에 대한 효율적인 관리) 관광두레사업에 참여하는 주민사업체 수 가 증가하고 유사 지원 사업이 늘어남에 따라, 지원 단계에서 지원금을 부정 수급하거나 사업 경영 단계에서 관광두레사업 취지에 맞지 않게 운영하는 사 례 등을 관리할 필요가 있음

- (지속적인 관광두레사업 지향 가치 확산 및 지자체 조례 제정 근거) 관광두레 사업은 지역사회 기반형 관광(community based tourism) 시스템을 마련하 는 사업임. 지원이 완료된 후에도 주민 주도 관광사업 활성화가 이루어지려면, 지방자치단체가 조례를 제정해 주민 주도, 지역 기반 관광 사업을 육성을 할 수 있도록 근거 법이 만들어질 필요가 있음 
- (관광두레사업의 안정적 추진과 지속적 성과 도출) 지속가능한 관광 실현, 주 민 주도 관광을 통한 지역경제 순환, 공동체 의식 향상 등 관광두레사업의 성 과를 공고히 하고, 안정적으로 사업을 추진할 수 있도록 법적 근거가 필요함

(2) 법 제·개정 시 고려 사항

- 관광두레사업의 목적 및 개념 정의. 주민 주도에 대한 명확한 정의

- 관광두레사업에 대한 이해를 위해 사업 목적 및 정의, 관광두레사업의 정체 성을 나타내는 주민 주도, 관광두레 $\mathrm{PD}$ 의 중간지원 또는 코디네이팅, 지역 성(로컬리티), 비즈니스 모델의 혁신성 등의 정의가 포함될 필요가 있음

- 주민사업체, 관광두레협의회 등의 법적 지위 보장 및 지원

- 관광두레사업을 통해 육성한 주민사업체, 관광두레협의회와 주민공동체가 주 민사업체로서 창업 및 경영개선 하는 데 필요한 행·재정적 지원 근거가 필요하 며, 창업 및 경영 개선을 완료한 주민사업체의 성장 발전을 위한 지원이 필요함

- 전문인력(관광두레PD) 양성 및 활동 지원

- 관광두레PD 선발, 자격, 활동내용 및 범위 등에 대한 근거와 관련 조직의 네트워크 주체로서 관광두레 $\mathrm{PD}$ 를 인식할 수 있도록 근거가 필요함

- 총괄지원기관과 중간지원조직 설립 및 운영

- 관광두레사업 취지와 목적에 맞게 사업을 추진하고, 안정적인 성장과 발전을 위해 총괄지원기관을 설립하고 총괄지원기관과 연계하여 광역 및 기초 지방 자치단체에서도 중간지원조직을 설립 및 운영할 수 있는 근거가 필요함

- 지방자치단체 역할

- 지방자치단체는 지원할 부분을 정확히 이행할 수 있도록 법적 근거가 필요 하며 이외에 주민사업체 통계, 지자체 유휴공간이나 국공유 자산 활용 등에 대한 다양한 의견이 제시됨

- 전문가 의견으로 관광두레사업의 고유성과 정체성을 명확히 하고, 주민사업체 에 대한 ‘규제'보다 '진흥', '육성'에 초점을 맞출 필요가 있다는 의견이 제기됨 


\section{다. 시사점}

- 관광두레사업을 통한 지역관광의 긍정적 변화

- 2019년까지 관광두레 주민사업체의 누적 매출액은 426억4천만 원으로, 지 역자원 활용 및 지역 내 순환 등을 고려할 때 지역경제 파급효과는 더 클 것으로 예상됨. 지역주민들이 관광 주체로 성장하고, 관광두레 $\mathrm{PD}$ 라는 기획 자를 양성해 지역 활성화 주체로 활동하게 하는 등 지역관광의 인적 역량 강화에 기여함

- 관광두레사업의 제도적·체계적 성장과 발전에 한계

- 관광두레사업은 단계별·현장밀착형 방식으로 주민사업체를 육성하도록 설 계되어 각 지역의 여건과 상황에 맞게 진행될 수 있도록 유연함을 갖추었으 나, 이에 대한 법적 근거가 불명확하여 사업 추진에 어려움이 발생함

- 특히 지방자치단체 역할에 대한 법적 규정이 미비하여 이해와 관심도 차이 에 따라 성과 도출에서 지역 편차가 나타나고 행-재정적 협력 수요가 발생 하여도 법적 근거가 없어 난항을 겪음

- 관광두레사업의 성과 지속 창출 및 체계적 발전을 위한 근거 법령 필요

- 관광두레사업의 체계적 발전은 물론 지방자치단체 지원 및 조례 제정의 근거, 지방자치단체 참여도와 지원 의지 고취, 지역 관광자원 활용-연계의 보장, 지역 주민과 전문가 등 관광두레사업 참여 활성화 기반, 주민사업체에 대한 효율적인 관리, 지역 내 주민주도 관광사업 가치 확산의 지속성 측면에서 법제화가 필요함

\section{3. 관광두레사업 관련 법령 및 유사사례 분석}

\section{가. 관광두레사업 관련 법령}

1) 관광진흥법

- 「관광진흥법」은 1986 년 제정된 법률로 관광사업과 관광개발, 그리고 관광진흥 등 실제적으로 관광분야 전반을 포괄하는 종합법적 성격을 지니고 있음 
- 종합법적 성격에 따라 관광사업 발전을 위해 필요한 비전과 목표, 다양한 정책 수단 등에 대한 근거를 제공해야 함에도 불구하고 변화된 여건을 반영할 수 있는 항목이 제한되어 새로운 관광 분야에 대한 근거 법제로서 한계가 있는 상황임

- 관광법제의 한계를 개선하기 위해 관광진흥법의 분법 등 관광법제 개편에 대 한 논의가 이루어지고 있음. 관광진흥법 분법화 진행 사항을 고려하되, 신속한 대응이 요구되는 입법 사안에 대해서는 현행 관광진흥법 일부개정을 검토할 수 있음

- 2013 년부터 추진한 관광두레사업은 「관광진흥법」 제 48 조제 4 항에 근거하여 관광 진흥을 위한 사업의 일환으로 추진되었으며 2018년12월24일, 관광산업 진흥 사업과 관련하여 제 47 조의7이 신설되면서 문화체육관광부장관은 관광산 업의 활성화를 위하여 대통령령으로 정하는 바에 따라 각 호의 사업을 추진할 수 있게 됨

- 관광진흥법 제 48 조제 4 항과 제 47 조의 7 이 관광두레사업의 근거 조항으로 볼 수 있음. 하지만 제 48 조의제 4 항, 제 47 조의7에는 '관광두레'사업의 명칭이나 ‘주민 주도형' 과 같이 관광두레사업 특성이 반영된 내용이 명시되지 않아 지방 자치단체에서는 사업과 관련한 행위를 할 때 법적 근거로 해석하는 데 어려움 을 표함

「관광진흥법」의 관련 법령

제47조의7(관광산업 진흥 사업) 문화체육관광부장관은 관광산업의 활성화를 위하여 대통령령으로 정하 는 바에 따라 다음 각 호의 사업을 추진할 수 있다.

1. 관광산업 발전을 위한 정책·제도의 조사·연구 및 기획

2. 관광 관련 창업 촉진 및 창업자의 성장·발전 지원

3. 관광산업 전문인력 수급분석 및 육성

4. 관광산업 관련 기술의 연구개발 및 실용화

5. 지역에 특화된 관광 상품 및 서비스 등의 발굴·육성

6. 그 밖에 관광산업 진흥을 위하여 필요한 사항

제48조(관광 홍보 및 관광자원 개발) (1) 문화체육관광부장관 또는 시·도지사는 국제 관광의 촉진과 국민 관광의 건전한 발전을 위하여 국내외 관광 홍보 활동을 조정하거나 관광 선전물을 심사하거나 그 밖 에 필요한 사항을 지원할 수 있다. 
(2) 문화체육관광부장관 또는 시·도지사는 제1항에 따라 관광홍보를 원활히 추진하기 위하여 필요하면 문화체육관광부령으로 정하는 바에 따라 관광사업자등에게 해외관광시장에 대한 정기적인 조사, 관광 홍보물의 제작, 관광안내소의 운영 등에 필요한 사항을 권고하거나 지도할 수 있다.

(3) 지방자치단체의 장, 관광사업자 또는 제54조제1항에 따라 관광지·관광단지의 조성계획승인을 받은 자는 관광지·관광단지·관광특구·관광시설 등 관광자원을 안내하거나 홍보하는 내용의 옥외광고물(屋外 廣告物)을 「옥외광고물 등의 관리와 옥외광고산업 진흥에 관한 법률」의 규정에도 불구하고 대통령령으 로 정하는 바에 따라 설치할 수 있다.

(4) 문화체육관광부장관과 지방자치단체의 장은 관광객의 유치, 관광복지의 증진 및 관광 진흥을 위하여 대통령령으로 정하는 바에 따라 다음 각 호의 사업을 추진할 수 있다.

1. 문화, 체육, 레저 및 산업시설 등의 관광자원화사업

2. 해양관광의 개발사업 및 자연생태의 관광자원화사업

3. 관광상품의 개발에 관한 사업

4. 국민의 관광복지 증진에 관한 사업

5. 유휴자원을 활용한 관광자원화사업

2) 지방자치단체 조례

(1) 광역시·도 단위

- 광역시·도 가운데 전라남도가 유일하게 관광두레사업 관련 조례를 제정함. 전라 남도는 2014년 곡성군, 여수시 등을 시작으로 관광두레사업을 추진해 왔으며, 지역별 관광두레 현황을 보면 광역시·도 가운데 가장 높은 $17.2 \%$ 로 나타남

- 전라남도는 ‘관광두레’라는 직접적인 사업 명칭 대신 ‘주민 주도 관광사업’이 라는 포괄적인 명칭을 사용해「전라남도 주민 주도 관광사업 육성 및 지원 조 례」를 2020년5월21일(조례 제5075호)에 제정함

- 해당 조례는 총 12 조로 구성되었으며, 주민 주도형 관광사업에 대한 목적(제1조) 및 정의(제2조), 사업 지원(제7조), 협력체계 구축(제8조), 주민 참여(제9조), 사무 의 위탁(제 10 조) 등 주민 주도형 관광사업 육성과 지원을 위한 체계를 갖춤

- 특히 제2조 정의에 주민 주도형 관광사업이란 지역관광객을 대상으로 지역 주민 고용과 소득창출을 위하여 자발적·협력적으로 경영하는 관광사업으로 명시함으로써, 주민들의 자발적·협력적 관광 경영에 기초한 관광두레사업 의 고유 특성을 반영함 
(2) 기초지방자치단체 단위

- 많은 지자체들이 관광 진흥 조례를 제정·운영하고 있으나, 현재 기초지방자치 단체 조례로 관광두레사업에 대한 내용을 포함하고 있는 경우는 의정부시가 유일함

- 특히 의정부시는 관광두레사업 대상지역이 아님에도 불구하고, 2018년3월15 일 “의정부시 관광 진흥 조례”를 제정(경기도의정부시조례 제2845호)하고 관 광두레사업을 추진하는 관광사업자 단체 및 관광사업자를 지원할 수 있는 조 항을 포함함

- 제5조(관광객 유치 지원 등) 제1항에 시장은 관광객 유치 또는 관광사업 육 성을 위하여 다음 각 호의 어느 하나에 해당하는 사업을 추진하는 관광사업 자 단체 또는 관광사업자를 지원할 수 있다고 하고, 제3호에 관광두레사업 을 포함함

- 안성시는 2019년 관광두레사업 대상지역으로 신규 선정되었으며, 현재 관광 두레PD의 역할과 주민사업체 지원 필요성 등을 인지하고 관광 진흥 조례 전 부개정을 추진 중임. 전부개정(안)에 “주민주도 관광사업” 및 “관광두레사업 지원” 등을 명시함

\section{나. 유사 사례2)}

1) 마을기업육성지원법(안) 제정 필요성

(1) 사업 개요

- 행정안전부는 2010년 시범 도입한 '자립형 지역공동체사업’을 지역주민이 지 역자원을 활용한 수익사업을 통해 공동의 지역문제를 해결하고, 소득 및 일자 리를 창출하여 지역공동체 이익을 실현하는 '마을기업 육성사업' 으로 발전시킴

2) 지역주민이 각종 지역자원을 활용한 수익사업을 통해 공동의 지역문제를 해결할 수 있도록 육성한다는 측면 에서 관광두레사업과 성격이 유사하며, 직접적 근거 법령 없이 시행 지침에 근거해 매년 사업을 추진 중인 ‘마을기업 육성사업’을 대상으로 법률 제정 필요성과 법률(안) 주요 내용 등을 분석함 
- 현재 마을기업 육성사업은 매년 행정안전부에서 배포하는 "마을기업 육성사업 시행 지침"에 근거해 추진되고 있으며 지침에는 마을기업과 육성사업의 이해 (정의, 신청절차 및 심사기준 등), 마을기업의 관리(마을기업 지정-약정 체결 및 변경, 사업비 지원·집행 및 정산 등), 기관별 역할 및 평가 등의 내용이 포 함되어 있음

(2) 법률 제정의 필요성

- 마을기업육성지원법(안)은 별도 법률 제정 필요성으로서 1) 마을기업에 법적 지위 부여, 2) 지역문제 해결, 일자리 창출 등 지역공동체 이익을 실현하고 지 역사회로 수익을 환원하는 순환구조 마련을 위한 제도적 근거 필요, 3) 마을기 업들의 성장단계별 맞춤형 자립지원 필요 및 법적 근거 필요, 4) 마을기업 지 원 내실화, 5) 부처·지자체별로 추진되는 마을기업 관련 정책 조정 및 통합적 관리, 6) 관련 예산편성의 유연성 확보와 전문 지원기관(중간지원조직, 마을기 업지원기관 등) 설립 필요 등을 제시함

2) 마을기업육성지원법(안) 주요 내용

(1) 법제화 추진 과정

- 마을기업 육성 사업이 2011년부터 지침에 의거해 추진되어 옴에 따라, 행정안 전부는 별도 법률 제정을 위해 관련 연구 및 토론회 개최 등의 노력을 기울임 - 2015년 한국법제연구원에 ‘마을기업 육성 관련 법제 분석'을 의뢰, 2019년 '마을기업 육성 지원에 관한 법률안 및 동법 시행령 제정 연구' 용역 진행, 같은 해 7월 마을기업육성법 제정 토론회 개최

- 20 대 국회에서는 박정 의원의 대표 발의를 통하여 해당 법안이 상정되었으나 임기 만료로 폐기된 후 2020년 6월 법률안이 제안되면서 21대 국회에 재상정 되었음 
〈표 3〉마을기업육성사업의 법제화 추진 과정

\begin{tabular}{|c|c|c|c|c|}
\hline 구분 & 법률안명 & 제안자 & 소관위원회 & 진행 과정 \\
\hline 행정안전부 & \multicolumn{4}{|c|}{ - 『마을기업 육성 관련 법제 분석』법제분석지원 연구(신청기관: 행정안전부) (‘15.9) } \\
\hline 행정안전부 & \multicolumn{4}{|c|}{ - 『마을기업 육성 지원에 관한 법률안 및 동법 시행령 제정 연구』 용역 진행('19.5.1-10.31.) } \\
\hline 행정안전부 & \multicolumn{4}{|c|}{ - 『마을기업육성지원법』제정 토론회 개최(‘19.7.5.) (제2회 대한민국 사회경제적 박람회) } \\
\hline $\begin{array}{c}\text { 20대 국회 } \\
\text { (2016 } \\
\text { 2020년) }\end{array}$ & $\begin{array}{c}\text { 마을기업 } \\
\text { 육성지원 } \\
\text { 법안 }\end{array}$ & $\begin{array}{l}\text { 박정 의원 } \\
\text { 등 } 10 \text { 인 }\end{array}$ & $\begin{array}{l}\text { 행정안전 } \\
\text { 위원회 }\end{array}$ & $\begin{array}{l}\text { - 법률안 제안('19.5.15.) } \\
\text { - 행정안전위원회 회부('19.5.16.) } \\
\text { - 행정안전위원회 상정('19.11.11.) } \\
\text { - 제371회 국회(정기회) 제10차 전체 회의에서 상정 } \\
\quad \text { /제안 설명/검토보고/대체설명 등('19.11.11.) } \\
\text { - 국회 임기만료로 폐기('20.5.29.) }\end{array}$ \\
\hline $\begin{array}{c}\text { 21대 국회 } \\
\text { (2020 } \\
\text { 2024년) }\end{array}$ & 동일 & $\begin{array}{l}\text { 박정 의원 } \\
\text { 등 } 18 \text { 인 }\end{array}$ & $\begin{array}{l}\text { 행정안전 } \\
\text { 위원회 }\end{array}$ & $\begin{array}{l}\text { - 법률안 제안 ('20.6.1.) } \\
\text { • 행정안전위원회 회부('20.6.29.) } \\
\text { • 행정안전위원회 상정('20.9.10.) } \\
\text { • 제382회 국회(정기회) 제2차 전체 회의에서 } \\
\text { 상정/제안설명/검토보고/대체설명 등('20.9.10.) }\end{array}$ \\
\hline
\end{tabular}

(2) 마을기업육성지원법(안) 구성 및 주요 내용

- "마을기업육성지원법안"은 일반적인 지원법의 조문 구성과 장절 체계를 따라 총칙, 마을기업 육성 추진체계, 지정 및 육성, 기반조성, 보칙 등 5개 장으로 이루어짐

- 총칙에는 목적, 정의, 국가 및 지방자치단체의 책무, 마을기업의 역할과 의 무, 다른 법률과의 관계 등을 담음

- 마을기업 육성 추진체계에는 종합계획의 수립, 시·도별 지원계획, 실태조 사, 마을기업육성위원회, 시·도별 마을기업육성위원회 등 계획과 조사, 마 을기업 육성 추진주체에 대한 내용을 포함함

- 마을기업의 지정 및 육성에는 마을기업의 지정, 마을기업에 대한 지원, 조 세감면 및 사회보험료의 지원, 마을기업의 지정취소 등을 담음

- 마을기업 육성 기반조성에는 마을기업의 사업, 지원기관, 포상, 감독, 권한. 업무의 위임·위탁 등의 내용을 포함함

- 마지막으로 보칙에는 과태료와 관련한 사항을 담음 


\section{다. 시사점}

- 관광두레사업의 확장성과 실효성 제고를 위한 법적 근거 필요

- 관광두레사업은 관광진흥법에 근거하여 추진 중에 있으나, 지역주민 공동체 의 주도적·협력적 참여에 기반하여 지속가능한 지역관광을 도모하는 등 관 광두레사업 확장성과 실효성 제고를 위해서는 명확한 법적 근거가 필요함

- 지자체 협력 지원 및 조례 제정 기반이 되는 법적 근거 필요

- 지방자치단체 조례를 통한 근거 마련도 가능하나, 지방자치단체마다 여건이 상이하고 관광두레사업에 대한 관심도와 협력 정도에 차이가 있음

- 상위 법령에 근거 조항을 마련함으로써 주민 주도 관광사업 추진에 대한 국 가 관광 정책의 방향성을 제시하는 등 조례 제정 기반을 마련할 필요가 있음

- 별도 법률 제정 시, 사회적 분위기 조성 및 합의점 도출 필요

- 별도 법률 제정 시, 입법 목적에 따른 내용을 종합적으로 포함할 수 있음. 마을기업육성지원법(안)의 경우, 목적, 정의, 마을기업의 역할과 의무에서부 터 마을기업 육성 추진체계, 마을기업의 지정 및 육성 등의 사항을 포괄함 - 그러나 해당 법률에 대한 국민적 공감대와 부처 간 합의점 도출이 필요함

\section{4. 관광두레사업 법제화 방안}

\section{가. 법제화 필요성}

1) 관광두레 법제화의 필요성

- 관광두레사업의 제도적·안정적 추진

- 관광두레사업은 주민들이 직접 만들고 경영하는 관광사업체 창출, 주민 소 득과 일자리 창출로 지역 경제 활성화, 지역관광 주체 육성, 지역주민 인식 변화 및 공동체성 강화, 정책 패러다임 변화 선도 등의 성과를 창출함

- 관광두레사업이 관광사업의 다양성과 창의성을 확대하여 지역관광 활성화와 관광산업 경쟁력 향상에 기여한다는 측면에서 제도적·안정적 추진이 필요함 
- 관광두레사업 추진 시, 대내·외 협력과 지원 유도

- 다양한 성과에도 불구하고, 명확한 법적 근거 미비에 따라 관광두레PD 역 할과 관광두레사업의 필요성에 대한 이해와 협력의 편차 발생, 관광두레사 랑방 및 주민사업체 육성 지원 어려움, 관광두레사업 지원 완료 이후 주민 사업체 사후 관리를 위한 중간지원조직 운영 어려움 등이 제기됨

- 또한 관광두레사업은 소프트웨어 및 휴먼웨어 중심으로 추진되어 하드웨어 적 지원이 결합될 필요가 있음. 지방자치단체를 비롯해 다양한 기관과의 연 계와 협력, 지원을 유도하기 위해 관광두레사업의 방향성과 추진체계에 대 한 법제화가 필요함

- 주민 주도 관광생태계 구축을 위한 법·제도적 기반 구축

- 관광두레사업이 '주민 주도 관광 사업 육성을 통한 지속가능한 지역관광 활 성화라는 목표 달성 및 실효성을 제고하기 위해서는 사업기간 이후에도 지 방자치단체가 관련 정책을 펼칠 수 있는 법·제도적 기반이 필요함

- 이를 통해 중앙과 지역의 역할을 배분하고, 관광두레 $\mathrm{PD}$, 중간지원기관 등 에 대한 지원 근거를 마련할 필요가 있음

- 관광두레 주민사업체에 법적 지위를 부여해 안정적 성장 기반 조성

- 관광두레 주민사업체의 창업 및 경영개선 시 필요한 하드웨어 등은 타 부처 사업과 연계하거나 지방자치단체의 지원을 필요로 하지만 주민사업체에 대 한 법적 지위 부재로 한계가 있음. 관광두레 주민사업체에 대한 법적 지위 를 부여하여 안정적인 성장 기반을 조성할 필요가 있음

\section{2) 관광두레 법제화 기대효과}

- 지역문제 해결과 일자리 창출 확대

- 주민 주도 방식은 지역주민이 주체가 되어 지역사회 현안 해결에 자발적으 로 참여하는 것임. 관광두레사업의 안정적 추진을 통해 지역주민이 주도하 여 지역의 문제를 관광 사업으로 해결하고, 이 과정에서 일자리가 만들어 지고 주민 소득이 향상될 수 있음 
- 최근 사회적 경제 영역의 활성화 필요성과 함께 일자리 창출이 주요한 정책 화두로 대두되고 있는 만큼, 관광두레 법제화를 통해 이러한 정책적 요구에 보다 효과적으로 부응할 것으로 기대함

- 시설 조성보다 콘텐츠 운영으로 지역 관광개발 방향성 전환

- 관광두레사업은 물리적 관광 매력물 개발보다는 지역 고유의 자원이나 매 력물을 어떻게 관광 사업화하고 지역 주민들이 경제적인 편익을 누릴 수 있 도록 하느냐에 초점을 두고 있음

- 관광두레 법제화는 이러한 정책적 방향성을 나타낼 수 있으며, 지방자치단 체가 기존 자원의 다양한 연계와 활용, 유휴화 완화를 위한 소프트웨어형 사업에 방점을 두도록 유도할 것으로 기대함

- 지역관광 차별성 및 매력성 향상, 주민 주도 지역관광 발전 도모

- 지역주민이 지역자원을 활용하여 직접 관광 사업을 운영하면 타 지역과는 다른 콘텐츠 매력이 발산되어 차별성이 확보되고 이 과정에서 지역공동체 가 회복될 수 있음

- 관광두레 법제화를 통해 지역사회 기반의 관광 콘텐츠가 안정적으로 개발 됨으로써 지역 간 차별성과 매력성을 향상할 수 있으며, 주민 주도 지역관 광의 발전을 꾀할 수 있음

\section{나. 법제화 방향 및 범위}

1) 법제화 대안

(1) 관광진흥법 내 조항 신설

- 관광진흥법은 관광을 진흥하기 위한 법률적 기반을 제공하고 있으므로 관광진 흥법에 관광두레사업에 대한 근거 조항을 마련하되, 두 가지 대안을 고려할 수 있음

- 제 48 조의 12 부터 필요 조항 신설

- 신설 조문은 관광진흥법 “제4장 관광의 진흥과 홍보”의 맨 마지막에 두어 관광두레사업을 국가의 관광 진흥 정책의 일환으로 인식하게 하고 제 48 조 의12부터 관광두레사업의 법적 근거로서 필요한 조항을 신설함 
- 관광진흥법 제 48 조제4항제6호 신설

- 관광진흥법 제 48 조제 4 항에 근거하여 관광 진흥을 위한 사업의 일환으로 추 진되어 왔으며 제 3 호 관광상품의 개발에 관한 사업, 제 4 호 국민의 관광복 지 증진에 관한 사업, 제5호 유휴자원을 활용한 관광자원화사업이 관광두 레사업과 관련성은 있지만, 직접적이고 명확한 근거 법령으로는 부족함

- 관광두레사업에 대한 명확한 법적 근거를 위해 제6호에 관광두레사업 성격 이나 특성을 규정하는 표현으로 “주민 주도의 지역관광 활성화 사업” 혹은 “주민공동체에 의한 관광자원화사업”을 신설함

(2) 관광진흥법 제47조의7을 근거로 동법 시행령에 조항 신설

- 관광진흥법 제 47 조의 7 제 2 호와 제 5 호에 따르면, 문화체육관광부장관은 대통 령령으로 정하는 바에 따라 '관광 관련 창업 촉진 및 창업자의 성장·발전 지 원', '지역에 특화된 관광 상품 및 서비스 등의 발굴·육성'과 관련한 사업을 추진할 수 있음

- 관광진흥법 제 47 조의7을 근거로 시행령에 관광두레사업의 직접적 근거를 마련함

(3) 별도의 지원 법률 제정

- 관광두레사업 추진을 위한 별도의 지원 법률을 제정함. 기존의 관광진흥법은 체계상, 내용상 여러 내용이 혼재되어 있으므로, 별도의 지원 법률 제정을 통 해 중앙정부의 주민 주도 지역관광 활성화 사업 추진에 대한 의지를 분명히 할 수 있음

2) 대안별 고려사항

- 입법 과정의 편의성은 관광진흥법 시행령 내 조문 신설 $\rightarrow$ 관광진흥법 내 조문 신설 $\rightarrow$ 별도 지원 법률 제정 순으로 소요 시간과 행·재정적 소모가 큼

- 입법 결과의 효과성은 위의 순서와 반대임 
〈표 4〉대안별 고려사항

\begin{tabular}{|c|c|c|c|c|c|}
\hline \multicolumn{2}{|c|}{ 대안 } & $\begin{array}{l}\text { 법제화 } \\
\text { 시점 }\end{array}$ & $\begin{array}{l}\text { 입법 과정 } \\
\text { 의 편의성 }\end{array}$ & $\begin{array}{l}\text { 입법 결과 } \\
\text { 의 효과성 }\end{array}$ & 고려사항 \\
\hline \multirow{2}{*}{$\begin{array}{l}\text { 1. 관광진흥법 } \\
\text { 내 조항 } \\
\text { 신설 }\end{array}$} & $\begin{array}{l}1-1 . \\
\text { 제48조 12부터 } \\
\text { 필요 조항 신설 }\end{array}$ & \multirow{2}{*}{ 단기 } & 2 & 2 & $\begin{array}{l}\text { - 관광두레사업의 안정적·체계적 추진을 } \\
\text { 위한 내용을 담을 수 있지만, 조항의 내 } \\
\text { 용이 너무 많아질 경우 관광진흥법 내 타 } \\
\text { 조항과 불균형 문제 제기 가능 }\end{array}$ \\
\hline & $\begin{array}{l}1-2 . \\
\text { 제48조제4항 } \\
\text { 제6호 신설 }\end{array}$ & & 1.5 & 2 & $\begin{array}{l}\text { - 입법 과정의 편의성은 1-1안보다 조금 } \\
\text { 더 수월. 결과의 효과성은 1-1안과 유사 } \\
\text { - 다만 관광두레사업과 관련하여 시행령에 } \\
\text { 담을 수 있는 조항이 더 축약될 가능성 }\end{array}$ \\
\hline \multicolumn{2}{|c|}{$\begin{array}{l}\text { 2. 관광진흥법 제47조의7을 } \\
\text { 근거로 동법 시행령에 조항 } \\
\text { 신설 }\end{array}$} & 단기 & 1 & 3 & $\begin{array}{l}\text { - 시행령은 국무회의 의결로 개정이 } \\
\text { 가능해 입법 과정이 상대적으로 수월함 } \\
\text { - 법률에 규정한 사항에 비해 홍보효과 및 } \\
\text { 법적 구속력에 한계 } \\
\text { - 제47조의7은 문화체육관광부장관이 관광 } \\
\text { 산업 진흥 사업을 할 수 있다고 명시하고 } \\
\text { 있기 때문에, 지방자치단체 등의 지원과 } \\
\text { 협력을 이끌어내고자 하는 등 본 법제화 } \\
\text { 의 취지를 살리기에 다소 부족 } \\
\text { - 관광산업 진흥으로 범주화되어 신규 모델 } \\
\text { 로의 성격이 약화될 가능성 }\end{array}$ \\
\hline \multicolumn{2}{|c|}{ 3. 별도의 지원 법률 제정 } & $\begin{array}{l}\text { 중 } \\
\text { 장 } \\
\text { 기 }\end{array}$ & 3 & 1 & $\begin{array}{l}\text { - 관광두레사업의 안정적·체계적 추진을 } \\
\text { 위한 맞춤형 법률로서 입법 효과 높음 } \\
\text { - 신규 법률 제정은 평균 1년 } 6 \text { 개월에서 } \\
\text { 2년 정도의 시간이 소요 } \\
\text { - 사회적 관심과 부처 간 합의점 도출 필요 }\end{array}$ \\
\hline
\end{tabular}

주: 입법 과정의 편의성과 입법 결과의 효과성에서 제시한 숫자는 각 대안별 편의성과 효과성 측면의 순위임

2) 법제화 범위 및 내용

(1) 법제화 범위 설정

- 정책사업명 법률 명시 여부

- “관광두레”라는 정책사업명을 법률에 명시하는 것과 관련해 여러 이견이 있 는 바, 이를 종합적으로 검토하여 본 연구에서는 별도 법률 제정 시 "관광두 레 진흥을 위한 지원 법률”, “주민공동체 기반의 관광 사업 육성을 위한 지 원 법률”을 제안함. 관광진흥법과 동법 시행령 개정 시에는, "주민 주도 지 역관광 활성화 사업”, “주민공동체에 의한 관광자원화 사업”을 제안함

- 별도의 법률 제정 시 포함 사항

- 관광두레사업의 안정적·제도적 성장과 발전, 체계적인 주민사업체의 육성· 
지원 관점에서 별도의 지원 법률을 제정함. 별도 지원 법률(안)은 통상적인 진흥법의 장·절 체계 및 조문 구성을 따라 총칙, 추진체계, 사업의 내용, 기 반 조성, 보칙 등 5개 장으로 구성함

- 관광진흥법 및 동법 시행령 일부 개정 시 반영 사항

- 관광진흥법 일부 개정을 추진하는 경우 새로운 법제화 필요성과 기존 조문 체계와 조화를 고려하며 관광두레사업의 고유 특성 및 추진 방식, 기존 사

업 추진과정에서의 한계 해소 등을 고려함

- 또한 별도 법률에 제시되었던 목적, 정의, 국가 및 지방자치단체 책무 조항 등 관광진흥법 내에 담기 어려운 조항은 삭제하여 반영함

〈표 5〉 관광진흥법 일부 개정 시 반영사항

\begin{tabular}{|c|c|c|c|c|}
\hline 구분 & 조항 & 별도 법률 제정 시 필요 조문 & & 관광진흥법 일부 개정 시 반영사항 \\
\hline \multirow{3}{*}{$\begin{array}{l}\text { 제1장 } \\
\text { 총칙 }\end{array}$} & 제1조 & 목적 & $x$ & $\begin{array}{l}\text { 관광진흥법 목적 조항에 반영이 어려 } \\
\text { 우므로 제외 }\end{array}$ \\
\hline & 제2조 & 정의 & $x$ & $\begin{array}{l}\text { 신설 조문에서 약칭으로 해결하는 방안 } \\
\text { 고려 }\end{array}$ \\
\hline & 제3조 & 국가 및 지방자치단체의 책무 & $\times$ & $\begin{array}{l}\text { 관광진흥법에 없는 조문이므로 제외하되, } \\
\text { 국가 및 지방자치단체의 역할에 대한 내 } \\
\text { 용을 관광두레 지원 및 육성 부분에 포함 }\end{array}$ \\
\hline \multirow{4}{*}{$\begin{array}{l}\text { 제2장 } \\
\text { 관광두레 } \\
\text { 추진체계 }\end{array}$} & 제4조 & 관광두레사업 기본계획 등의 수립 & $\triangle$ & $\begin{array}{l}\text { 관련 기본계획 수립 제도화 필요성 검토 } \\
\text { 필요 }\end{array}$ \\
\hline & 제5조 & 실태조사 & $\triangle$ & 기본계획 반영 시 함께 반영 \\
\hline & 제6조 & 전담조직 & $\bigcirc$ & 핵심 조문, 별도 조문으로 신설 \\
\hline & 제7조 & 주민사업체 협의체의 구성 & $\triangle$ & $\begin{array}{l}\text { 관광진흥법 상의 지역관광협의회와 상이 } \\
\text { 하므로 반영 고려 }\end{array}$ \\
\hline \multirow{5}{*}{$\begin{array}{c}\text { 제3장 } \\
\text { 관광두레 지원 } \\
\text { 및 육성 }\end{array}$} & 제8조 & 관광두레사업의 범위 등 & $\bigcirc$ & 핵심 조문, 별도 조문으로 신설 \\
\hline & 제9조 & 사업 대상지역 선정 및 평가 등 & $\bigcirc$ & 핵심 조문, 별도 조문으로 신설 \\
\hline & 제10조 & 지방자치단체의 사업 & $\bigcirc$ & 핵심 조문, 별도 조문으로 신설 \\
\hline & 제11조 & 주민사업체의 등록 및 취소 & $\bigcirc$ & 핵심 조문, 별도 조문으로 신설 \\
\hline & 제12조 & 재정 지원 & $\bigcirc$ & 관광진흥법 보칙 제76조에 추가 \\
\hline \multirow{3}{*}{$\begin{array}{c}\text { 제4장 } \\
\text { 관광두레 기반 } \\
\text { 조성 }\end{array}$} & 제13조 & $\begin{array}{l}\text { 관광두레 관련 교육·홍보 및 } \\
\text { 정보의 제공 }\end{array}$ & $\bigcirc$ & 전담조직의 역할에 포함하여 반영 \\
\hline & 제14조 & 국·공유재산의 대부 등 & $\bigcirc$ & 관광진흥법 제76조제3항 보완 \\
\hline & 제15조 & $\begin{array}{l}\text { 관광두레 육성·지원을 위한 전문인 } \\
\text { 력 양성 }\end{array}$ & $\bigcirc$ & 핵심 조문, 별도 조문으로 신설 \\
\hline 제5장 보칙 & 제16조 & 권한·업무의 위임·위탁 & $\times$ & 관광진흥법 제80조 활용 \\
\hline
\end{tabular}


(2) 별도 지원 법률 각 조문별 입법 취지

- 제 1 조 목적

- 법률 제정을 통해 달성하고자 하는 목표를 명확하게 제시함. 국가 또는 지 방자치단체가 주민들이 주도적·협력적으로 지역 고유 자원을 연계·활용하 여 관광 사업을 창업 및 경영개선 하는 데 필요한 지원을 하도록 함

- 관광진흥법 일부개정 시에는 반영하기 어려움

- (목적) 이 법은 국가 또는 지방자치단체가 주민들이 주도적·협력적으로 지역 고유 자원을 연계·활용 하여 관광 사업을 창업 및 경영개선 하는 데 필요한 사항을 정함으로써 지역관광 활성화와 주민들의 경제적 이익 보장, 공동체 의식 향상 등 지속가능한 관광 발전을 실현하는 데 목적이 있다.

- 제2조 정의

- '관광두레'는 주민의 자발적 참여와 지역자원의 연계·활용을 통한 새로운 방식의 지역관광발전 모델을 의미하며, 관광두레사업은 이러한 지역관광발 전 모델을 조성하기 위한 사업을 의미함

- 주민사업체는 1) 특정한 지역 주민들의 주체적·자발적·협력적 참여를 바탕 으로 하며 2) 지역 내의 문화유적지와 먹을거리, 탐방로, 축제, 숙박시설 등 기존의 다양한 자원을 연계·활용함을 요소로 하고 3) 지역특화 브랜드와 관 광 사업을 창출하는 것을 목적으로 하며 4) 해당 주민들이 창업하고 그 운 영을 주도하는 지역관광 공동체라는 특성을 갖춘 것을 말함

- 관광진흥법 일부개정 시에는 별도 정의 조항을 넣지 않고, 관련 용어를 사용 한 조문에 설명을 적어 약칭을 사용하는 방식으로 규정하는 것이 일반적임

- (정의) (1) “관광두레사업"이란 주민의 자발적 참여와 지역자원의 연계·활용을 통한 새로운 방식의 지역관광발전 모델을 조성하기 위하여 문화체육관광부장관 또는 지방자치단체의 장이 실시하는 제8 조제1항 각 호의 사업을 말한다.

(2) “주민사업체”란 특정한 지역 주민들의 주체적·자발적·협력적 참여를 바탕으로 문화유적지와 먹을 거리, 탐방로, 축제, 숙박시설 등 지역 고유의 자원을 연계·활용함으로써 지역특화 브랜드와 관광 사업을 창출하기 위하여 해당 주민들이 창업하고 그 운영을 주도하는 지역관광 공동체를 말한다. 
- 제3조 국가 및 지방자치단체의 책무

- 법률의 목적 실현을 위해 국가 및 지방자치단체가 해야 할 책무를 명확하게 하고자 관련 내용을 포함하며 관광진흥법 일부개정 시에는 반영하기 어려움

- (국가 및 지방자치단체의 책무) (1) 국가는 관광두레사업의 지속적·체계적 추진을 위하여 필요한 행. 재정적 지원을 실시할 책무를 진다.

(2) 지방자치단체는 관광두레사업이 지역관광의 활성화를 촉진하고 주민 주도 관광생태계를 조성할 수 있도록 해당 지역 내 주민사업체에 대하여 필요한 행·재정적 지원을 할 책무를 진다.

- 제4조 관광두레 기본계획 등의 수립

- 관광두레사업 추진에 대한 기본계획과 시행계획 수립은 사업을 장기적 관점 에서 안정적·체계적으로 수행하도록 하는 요소이며, 추진체계의 중요 부분임

- 기본계획의 법적 성격은 행정계획이며, 해당 계획기간 동안에는 행정주체에 대한 내재적 구속력을 발생하기 때문에 사업의 안정적-체계적 추진이 가능함

- 특히 국가가 수립한 기본계획은 지방자치단체로 하여금 시행계획의 수립과 집행이라는 의무를 발생시키며, 예산을 확보하는 과정에서도 행정계획은 관련 기관간의 협의를 거쳐 수립되었다는 점에서 유용성을 발휘할 수 있음

- (관광두레 기본계획 등의 수립) (1) 문화체육관광부장관은 제1조의 목적을 달성하기 위하여 제8조제1 항 각 호의 사항이 포함된 관광두레사업 기본계획(이하, "기본계획"이라 한다)을 필요시 관계 중앙행 정기관의 장과 협의하고 지방자치단체의 의견을 들어 5 년 마다 수립하고 이를 지방자치단체의 장에 게 송부하여야 한다.

(2) 지방자치단체의 장은 기본계획의 범위에서 해당 지역에서의 관광두레사업 추진에 필요한 사항에 대하여 해마다 관광두레사업 시행계획(이하, "시행계획"이라 한다)을 수립하고 이를 문화체육관광부 장관에게 제출하여야 한다.

(3) 기본계획 및 시행계획의 수립절차 등에 필요한 사항은 대통령령으로 정한다.

- 제5조 실태조사

- 실태조사는 정책을 추진하는 데 기초가 되는 정보와 자료를 얻기 위한 수단으로 기본계획 수립과 연동하는 조문이며 사업 예산을 확보하는데 근거 조문이 됨

- 관광진흥법 일부개정 시 기본계획 수립에 대한 제도화 필요성 검토 후 반영할 필요가 있으며 실태조사의 범위와 조사 시기, 방법 등은 하위 법령으로 위임함 
- (1) 문화체육관광부장관은 기본계획과 시행계획을 효율적으로 수립·추진하기 위하여 관광두레사업에 대한 실태조사를 할 수 있다.

(2) 실태조사의 범위와 방법 등 필요한 사항은 대통령령으로 정한다.

- 제6조 전담조직(중간지원기관)

- 관광진흥개발기금의 관리 주체는 문화체육관광부이지만3), 단계별·맞춤형 지원 과정을 중요시하는 관광두레사업의 특성 상 다양한 활동이 수반됨

- 따라서 행정관청이 실제 업무는 민간기관에 위탁하여 실시할 필요가 있으 며 이를 위한 전담조직 지정 및 운영을 위해서는 법령 근거가 필요함

- 따라서 해당 조항은 관광진흥법 일부 개정 시 반영이 필요한 핵심 조문임

- (전담조직) (1) 문화체육관광부장관 또는 지방자치단체의 장은 주민 주도 관광사업 추진에 필요한 지 원을 하기 위하여 필요한 경우에는 대통령령 또는 해당 지방자치단체의 조례로 정하는 기관 중에서 그 지원을 전담하는 조직을 지정할 수 있으며, 그 조직의 운영 등에 필요한 경비를 지원할 수 있다. (2) 제 1 항의 전담조직에 대한 필요한 사항은 대통령령으로 정한다.

- 제7조 주민사업체 협의체의 구성

- 현재 관광두레협의회를 구성하고 있으나 지속적으로 성장·발전할 제도적 기반이 부족한 상황으로 주민사업체 협의체는 지역관광추진조직(DMO)로 발전하거나 주민 주도 관광생태계 조성을 위한 지역 전담조직으로 활동할 수도 있음

- 해당 조항은 관광진흥법 일부 개정 시 반영을 고려할 수 있음

- (주민사업체 협의체의 구성) (1) 주민사업체는 관광두레사업의 효율적 추진과 상호 부조 등을 위하여 협의체를 구성할 수 있다.

(2) 제 1 항의 협의체의 구성 및 운영, 지원에 관한 필요한 사항은 대통령령으로 정한다.

- 제8조 관광두레사업의 범위 등

- 관광두레사업을 추진할 법적 근거 조항으로 법령에서 재정지원을 규정하기 위해서는 지원 대상이 되는 사무가 신설되어야 하며, 이러한 사무는 국가와 지방자치단체 간의 배분이 필요함

3) 관광진흥개발기금법 제 3 조(기금의 관리) (1) 기금은 문화체육관광부장관이 관리한다. 
- 관광진흥법 일부 개정 시 반영이 필요한 핵심 조문임

- 중앙정부가 최장 5년까지 지원을 하는 기간에도 기초지방자치단체가 지원할 수 있는 체계가 갖추어져야 하며, 중앙정부의 지원이 종료된 후에도 해당 주 민사업체에 대하여 지방자치단체의 행·재정적 지원이 이루어질 필요가 있음

- 기초지방자치단체의 재정 구조가 광역지방자치단체와 연동되므로 광역지방 자치단체의 협력과 지원이 동반되어야 함

- (관광두레사업의 범위 등) (1) 문화체육관광부장관 또는 지방자치단체의 장은 지역관광의 활성화를 촉진하고 주민 주도 관광생태계를 조성할 수 있도록 각 호의 사항을 지원할 수 있다.

1. 주민사업체 발굴 및 육성 지원

2. 교육·홍보 및 정보의 제공

3. 시설 및 유휴공간 지원

4. 주민사업체 지원을 위한 전문인력 육성 및 활동비 지원

5. 지역자원 활용 콘텐츠 개발

6. 그 밖에 관광두레사업 지원·육성을 위하여 필요한 사항

(2) 문화체육관광부장관 또는 광역 및 기초지방자치단체의 장은 제 1 항의 지원 내용에 대하여 상호 간의 역할을 배분하며, 이에 대해서는 대통령령으로 정한다.

- 제9조 사업 대상지역 선정 및 평가 등

- 관광두레사업은 기초지방자치단체를 범위로 매년 공모를 통해 대상지역을 선 정해 기본 3년 간 지원하고, 매년 연차별 평가를 통해 종합평가하여 추가 2 년을 더해 최대 5년 간 지원이 가능함

- 사업성과 평가에 따라 지속 추진 타당성이 낮으면 해당 지역에 대한 사업을 종료하고, 종합평가를 진행하여 모범 사례 지역은 2 년간 추가로 지원함

- (사업 대상지역 선정 및 평가 등) (1) 문화체육관광부장관은 제8조의 사업을 효율적으로 실시하기 위 하여 해마다 기초지방자치단체 중에서 사업실시 대상지역을 선정하여 기본 3년 동안 지원을 실시하 며, 지원에 따른 실적을 매년 평가하여 평가 결과에 따라 지원을 차등하거나 지원을 종료하는 등의 조치를 취할 수 있다.

(2) 문화체육관광부장관은 제 1 항의 평가 결과를 반영하여 2 년의 범위에서 추가적인 지원을 실시할 수 있다.

(3) 제 1 항에 따른 선정 및 평가 기준과 그 밖에 대상 지역의 선정 및 지원에 관하여 필요한 사항은 대통령령으로 정한다. 
- 제 10 조 지방자치단체의 사업

- 주민사업체가 안정적 성장 기반을 갖추기에 기본 3년의 지원 기간이 부족할 수 있어 관광두레사업 대상지역으로 선정하기 이전부터 지역문제를 관광 사업으로 해결하려는 의지를 가진 공동체를 발굴하는 등의 사업을 지방자 치단체에서 추진하는 것이 보다 효과적일 수 있음

- 또 지원 기간이 종료된 이후에, 관광두레사업을 통해 육성한 주민사업체에 대한 후속 지원 및 관리가 필요함. 아울러 지역의 실정에 맞는 주민 주도 관광 사업을 계속하여 지원할 근거를 마련할 필요가 있음

- 관광진흥법 일부 개정 시 반영이 필요한 핵심 조문임

- (지방자치단체의 사업) 지방자치단체의 장은 제 9 조제 1 항의 대상 지역으로 선정되기 전에 해당 지역 내에서 제8조제 1 항 각 호의 사업을 독자적으로 시행하거나 제 9 조제 2 항의 지원이 종료된 이후 필요 한 사항을 조례로 정하는 바에 따라 지원할 수 있다.

- 제 11 조 주민사업체의 등록 및 취소

- 관광두레사업은 진흥 성격의 사업이기 때문에 주민사업체에 특별한 부담이 나 의무를 지워서는 안 됨. 하지만 국가 또는 지방자치단체 재정이 투입되 는 경우 지원 대상이 되는 주민사업체를 관리할 필요가 있으며, 지원 대상 에 포함할 수 있도록 명확한 근거를 마련한 필요가 있음

- 창업 및 경영개선을 완료한 주민사업체 법인격은 공동체 성격 및 사업 유형에 따라 협동조합, 영농조합법인, 주식회사 등 다양함. 관광진흥법에서 규정하는 관광사업자인 경우도 있으나, 관광사업 범주에 포함하지 않는 경우도 있음

- 관광두레사업의 단계별·맞춤형 지원을 체계적으로 시행하고 지방자치단체의 재 정이나 시설 지원 등의 대상이 되기 위해서는 별도의 등록 절차를 거치도록 함 - 등록은 의무가 아니라 지원을 받기 위한 전제조건으로 운영하고 과태료 등 은 부과하지 않음 4$)$

- 관광진흥법 일부 개정 시 반영이 필요한 핵심 조문임

4) 이러한 입법 방식은 최초 박물관 및 미술관 진흥법에서 시도되었고 지금은 상당히 많은 법률에서 이용하고 있음(박물관 및 미술관 진흥법 제 16 조제 1 항 등 참조) 
- (주민사업체의 등록 및 취소) (1) 이 법에 따른 지원을 받고자 하는 주민사업체는 문화체육관광부 장관 이 정하는 바에 따라 기초지방자치단체의 장에게 등록하여야 한다.

(2) 기초지방자치단체의 장은 주민사업체가 다음 각 호의 어느 하나에 해당하면 등록을 취소하거나 문화체육관광부 장관이 정하는 바에 따라 일정 기간 이 법에 따른 지원을 중단할 수 있다. 다만 제1 호에 해당하면 그 등록을 취소하여야 한다.

1. 거짓이나 그 밖에 부정한 방법으로 주민사업체 선정 및 등록을 한 때

2. 동일한 내용에 대하여 타 사업비와 중복하여 지원받았을 때

3. 주민사업체의 구성이나 운영 형태 등이 제 1 항에서 정하는 바에 부합하지 않을 때

4. 주민사업체와 관련하여 관광두레사업 등에 직접·간접적 영향을 미치는 민사 또는 형사 사건이 발생하였을 때

(3) 기초자치단체의 장은 주민사업체 등록 및 운영현황을 매년 12 월 말까지 문화체육관광부장관과 관할 광역자치단체의 장에게 통지하여야 한다.

- 제 12 조 재정 지원

- 관광두레사업의 안정적인 사업 추진을 위해서는 재정의 확보가 중요함. 예 산은 법적 근거가 마련되어야 안정적으로 확보할 수 있으며 관광진흥법 일 부개정 시, 보칙 제76조에 관광두레사업에 대한 내용을 추가하는 것을 고 려할 수 있음

- 예산 지출 법적 근거는 개별 법률에서는 예산을 지원할 수 있다는 점만 규정하 고, 「보조금 관리에 관한 법률과 동 법 시행령을 정비하는 것이 일반적이며 관광진흥개발기금 활용 근거는 관광진흥개발기금법에서 정하는 것이 원칙임

- (재정 지원) (1) 국가는 지방자치단체가 관광두레사업을 실시하는 데 필요한 재원을 보조금으로 지원 할 수 있다.

(2) 국가는 관광진흥개발기금법에 따른 관광진흥개발기금의 재원으로 관광두레사업을 실시하는 데 필 요한 지원을 할 수 있다.

- 제 13 조 관광두레 관련 교육·홍보 및 정보의 제공

- 관광두레사업의 지속적인 성장을 위해서는 관광객들이 주민사업체에 대한 정보를 충분히 인지하고 관련 상품과 서비스를 소비하여야 함. 따라서 지역 주민과 일반 국민을 대상으로 관광두레사업에 대한 교육·홍보 및 정보 제공 이 필요함

- 관광진흥법 일부개정 시, 전담조직의 역할 및 업무 범위에 대한 내용을 신 설하면서 해당 내용을 포함하는 것을 고려할 수 있음 
- (관광두레 관련 교육·홍보 및 정보의 제공) 문화체육관광부장관 또는 지방자치단체의 장은 관광두레 사업의 시행과 주민사업체에 대한 지원을 위하여 대통령령으로 정하는 바에 따라 교육, 홍보를 실시 하거나 관련 정보를 제공할 수 있다.

- 제 14 조 국·공유재산의 대부 등

- 관광두레 주민사업체나 전담조직에 대해 국가나 지방자치단체가 소유하는 행정재산이나 일반재산의 일부를 이용하게 할 필요가 있음. 이 경우 대부 또는 사용수익허가를 받는 요건이나 방식에서「국유재산법」과「공유재산 및 물품관리법」에서 까다롭게 규제하고 있는 사항에 대하여 특례를 인정할 필요가 있음. 대부료나 사용료의 금액을 감면해 주는 것도 지원에 필수적인 사항임

- 관광진흥법 일부개정 시, 기존 관광진흥법 보칙 제76조제3항을 보완하는 것을 고려할 수 있음

- 국유재산법에 대한 특례의 설정은 「국유재산특례제한법」에서 동 법 별표를 개 정하여야만 효력을 갖도록 통제하고 있어5) 해당 개정 작업도 병행되어야 함

- (국·공유재산의 대부 등) 문화체육관광부장관 또는 지방자치단체의 장은 주민사업체 또는 제6조의 전담조직에 대하여 국유재산 또는 공유재산을 대통령령으로 정하는 바에 따라 대부하거나 사용 수익 하게 할 수 있으며 대부료나 사용료를 경감할 수 있다.

- 제 15 조 관광두레 육성·지원을 위한 전문인력 양성

- 관광두레사업의 지역별 총괄책임자이자 중심적 매개 역할을 하는 관광두레 $\mathrm{PD}$ 는 관광두레사업의 주요 특징이지만 자격제도나 일반화된 명칭이 아니 기 때문에 법령에 그대로 반영하기에 어려움이 있음

- 관광진흥법 일부개정 시 반영이 필요한 핵심 조문임

- 법률에서 규정한 사항 외에 청년관광두레PD 및 세부 내용은 하위 법령 등에 서 구체화하도록 하여 그 역할을 명확히 하고 공정한 선정 및 운영을 도모함

5) 제4조(국유재산특례의 제한) (1) 국유재산특례는 별표에 규정된 법률에 따르지 아니하고는 정할 수 없다.

(2) 이 법 별표는 이 법 외의 다른 법률로 개정할 수 없다. 
- (관광두레 육성·지원을 위한 전문인력 양성) 문화체육관광부장관 또는 지방자치단체의 장은 관광두레 지원·육성을 위하여 대통령령으로 정하는 바에 따라 전문인력을 발굴·양성 및 평가하고 그 활동을 지원할 수 있다.

- 제 16 조 권한·업무의 위임·위탁

- 전담조직 등을 설정 또는 지정하는 것과 관련하여 행정기관이 수행할 업무 중 일부는 이들 전담조직에 위탁하여 수행할 필요가 있음

- 관광진흥법 일부개정 시에는, 현행 관광진흥법 제 80 조제 3 항에 민간위탁의 위탁 및 수탁기관과 대상을 정하고 있으므로 대상 업무만 추가하면 됨

- (권한·업무의 위임·위탁) 문화체육관광부장관 또는 지방자치단체의 장은 제8조제1항 각호의 지원 업 무에 관한 권한의 전부 또는 일부를 대통령령으로 정하는 바에 따라 제6조의 전담조직에 위탁할 수 있다.

\section{다. 법제화 방안}

- 앞서 대안으로 제시한 관광진흥법 일부개정(안), 관광진흥법 시행령 일부개정 (안), 별도 지원 법률(안)을 예시 형태로 규정함

1-1) 관광진흥법 제48조 내 조항 신설(안)

- 현행 관광진흥법 “제4장 관광의 진흥과 홍보”의 마지막에 위치하여 국가의 관 광진흥시책의 일환으로 “주민 주도 지역관광 활성화사업”을 명시함. 제48조 12 , 제 48 조 13 , 제 48 조의 14 를 신설함 
관광진흥법의 일부를 다음과 같이 개정한다.

제4장에 제 48 조의 12 부터 제 48 조의 14 까지를 각각 다음과 같이 신설한다.

제48조의12(주민 주도 지역관광 활성화사업 지원 등) (1) 문화체육관광부장관 또는 지방자치단체의 장 은 주민의 자발적 참여와 지역자원의 연계·활용을 통한 새로운 방식의 지역관광발전 모델을 조성하기 위하여 다음 각 호의 사항을 지원하는 주민 주도 지역관광 활성화사업을 추진할 수 있다.

1. 주민사업체(특정한 지역 주민들의 주체적·자발적·협력적 참여를 바탕으로 문화유적지와 먹을거리, 탐방로, 축제, 숙박시설 등 지역 고유의 자원을 연계·활용함으로써 지역특화 브랜드와 관광 사업 을 창출하기 위하여 해당 주민들이 창업하고 그 운영을 주도하는 지역관광 공동체를 말한다. 이하 같다)의 발굴 및 육성 지원

2. 교육·홍보 및 정보의 제공

3. 시설 및 유휴공간 지원

4. 주민사업체 지원을 위한 전문인력 발굴, 육성, 평가 및 활동비 지원

5. 지역자원 활용 콘텐츠 개발

6. 그 밖에 주민 주도 지역관광 활성화사업 지원·육성을 위하여 필요한 사항

(2) 문화체육관광부장관 또는 지방자치단체의 장은 제 1 항의 지원을 함에 있어 제 3 항과 제 4 항에서 정 한 사항을 고려하여 대통령령으로 정하는 바에 따라 상호 간의 역할을 배분한다.

(3) 문화체육관광부장관은 제 1 항의 사업을 효율적으로 실시하기 위하여 해마다 기초지방자치단체 중 에서 사업실시 대상지역을 선정하여 기본 3년 동안 지원을 실시하며, 지원에 따른 실적을 매년 평가 하여 평가 결과에 따라 지원을 차등하거나 종료할 수 있다.

(4) 문화체육관광부장관은 제 3 항의 평가 결과를 반영하여 2년의 범위에서 추가적으로 지원할 수 있다.

(5) 제 3 항에 따른 선정 및 평가 기준과 그 밖에 지원에 관하여 필요한 사항은 대통령령으로 정한다.

(6) 제3항에 따라 대상지역으로 선정된 기초자치단체의 장은 주민 주도 지역관광 활성화사업의 원활 한 추진과 진흥을 위하여 전문인력에 대한 사무공간 및 집기 제공과 교육 및 연수의 실시, 주민사업체 와의 회의 및 교육 공간의 제공 등 그 활동에 필요한 사항을 지원한다.

(7) 지방자치단체의 장은 제3항의 지역으로 선정되기 전에 해당 지역 내에서 제 1 항 각 호의 사업을 독자적으로 시행하거나 제 3 항의 지원이 종료된 후 필요한 후속지원을 할 수 있다.

제48조의13(주민 주도 지역관광 활성화사업의 전담조직 등) (1) 문화체육관광부장관 또는 지방자치단체 의 장은 주민 주도 지역관광 활성화사업 추진에 필요한 지원을 하기 위하여 필요한 경우에는 대통령 령 또는 해당 지방자치단체의 조례로 정하는 기관 중에서 그 지원을 전담하는 조직을 지정하여, 그 조직의 운영 등에 필요한 경비를 지원할 수 있으며 다음 각 호의 업무를 관장하게 할 수 있다.

1. 제48조의 12 제 1 항에 따른 주민사업체 지원 전문인력에 대한 역량 강화, 평가, 활동 지원과 관리

2. 주민사업체의 발굴 및 육성

3. 사업화계획의 수립 지원

4. 주민사업체의 창업과 경영개선 및 파일럿 사업 지원

5. 사업에 대한 모니터링, 평가

6. 주민 주도 지역관광 활성화사업 및 주민사업체 홍보·마케팅 등 사업 총괄 운영

(2) 제48조의12제 1 항제4호에 따른 전문인력은 다음 각 호의 업무를 수행한다.

1. 지역 현장에서 주민사업체의 발굴과 조직화, 창업 및 경영개선 지원까지 사업의 총괄 진행 
2. 주민사업체와 주민, 지방자치단체와 주민, 고객과 주민, 주민과 주민 사이에서 중간지원 역할의 수행

3. 지역 관광자원의 조사 및 지역의 주민 주도 지역관광 활성화사업 콘셉트 구상

4. 그 밖에 지역 주민사업체 지원·육성을 위하여 필요한 사업

제48조의14(주민사업체의 등록 및 취소) (1) 이 법에 따른 지원을 받고자 하는 주민사업체는 문화체육관 광부 장관이 정하는 바에 따라 기초지방자치단체의 장에게 등록하여야 한다.

(2) 기초지방자치단체의 장은 주민사업체가 다음 각 호의 어느 하나에 해당하면 등록을 취소하거나 문화체육관광부 장관이 정하는 바에 따라 일정 기간 이 법에 따른 지원을 중단할 수 있다. 다만 제1호 에 해당하면 그 등록을 취소하여야 한다.

1. 거짓이나 그 밖에 부정한 방법으로 주민사업체 선정 및 등록을 한 때

2. 동일한 내용에 대하여 타 사업비와 중복하여 지원받았을 때

3. 주민사업체의 구성이나 운영 형태 등이 제1항에서 정하는 바에 부합하지 않을 때

4. 주민사업체와 관련하여 관광두레사업 등에 직접·간접적 영향을 미치는 민사 또는 형사 사건이 발 생하였을 때

(3) 기초자치단체의 장은 주민사업체 등록 및 운영현황을 매년 12 월 말까지 문화체육관광부장관과 관할 광역자치단체의 장에게 통지하여야 한다.

제76조를 다음과 같이 한다.

제76조(재정지원) (1) 문화체육관광부장관은 주민 주도 지역관광 활성화사업 그 밖에 관광과 관련된 사 업을 하는 지방자치단체, 관광사업자 단체, 주민 주도 지역관광 활성화 전담기관 및 전문인력, 주민사 업체 또는 관광사업자에게 대통령령으로 정하는 바에 따라 보조금을 지급할 수 있다.

(2) 지방자치단체는 그 관할 구역 안에서 관광에 관한 사업을 하는 관광사업자 단체 또는 관광사업자 에게 조례로 정하는 바에 따라 보조금을 지급할 수 있다.

(3) 국가는 관광진흥개발기금법에 따른 관광진흥개발기금의 재원으로 주민 주도 지역관광 활성화사업 을 실시하는데 필요한 지원을 할 수 있다.

(4) 국가 및 지방자치단체는 「국유재산법」, 「공유재산 및 물품 관리법」, 그 밖의 다른 법령에도 불구하 고 관광지등의 사업시행자에 대하여 국유·공유 재산의 임대료를 대통령령으로 정하는 바에 따라 감면 할 수 있다.

(5) 문화체육관광부장관 또는 지방자치단체의 장은 주민사업체 또는 제48조의 13 제 1 항 및 제 2 항의 전담조직과 전문인력에 대하여 국유재산 또는 공유재산을 대통령령으로 정하는 바에 따라 대부하거나 사용 수익하게 할 수 있으며 대부료나 사용료를 경감할 수 있다.

제80조제3항에 제10호를 다음과 같이 신설한다.

10. 주민 주도 지역관광 활성화사업의 시행 (신설)

$$
\text { 부 칙 }
$$

이 법은 공포 후 1년이 지난 날 부터 시행한다. 


\section{1-2) 관광진흥법 제48조제4항제6호 신설}

- 현행「관광진흥법」(이하 “법”) 제 48 조제 4 항에 제 6 호를 신설하여, 관광객의 유치 및 관광 진흥 등을 위하여 문화체육관광부장관과 지방자치단체의 장이 추진할 수 있는 사업으로 “주민 주도 지역관광 활성화사업”을 명시함6)

\section{「관광진흥법 및 동법 시행령 일부개정(예시 안)」}

관광진흥법의 일부를 다음과 같이 개정한다.

제48조제4항에 제6호를 다음과 같이 신설한다.

6. 주민 주도 지역관광 활성화사업 (신설)

관광진흥법 시행령의 일부를 다음과 같이 개정한다.

제41조의7을 다음과 같이 신설한다. 그리고 현행 제 41 조의 7 부터 제 41 조의 13 은 각각 제 41 조의 8 부터 제41조의 14 로 이동한다.

제41조의7 (주민 주도 지역관광 활성화사업 지원 등) (1) 문화체육관광부장관과 지방자치단체의 장은 법 제48조제4항제6호에 따라 주민 주도 지역관광 활성화를 위하여 다음 각 호의 사항을 지원할 수 있다.

1. 주민사업체특정한 지역 주민들의 주체적·자발적·협력적 참여를 바탕으로 문화유적지와 먹을거리, 탐방로, 축제, 숙박시설 등 지역 고유의 자원을 연계·활용함으로써 지역특화 브랜드와 관광 사업 을 창출하기 위하여 해당 주민들이 창업하고 그 운영을 주도하는 지역관광 공동체를 말한다. 이하 같다)의 발굴 및 육성 지원

2. 교육·홍보 및 정보의 제공

3. 시설 및 유휴공간 지원

4. 주민사업체 지원을 위한 전문인력 발굴, 육성, 평가 및 활동비 지원

5. 지역자원 활용 콘텐츠 개발

6. 그 밖에 주민 주도 지역관광 활성화사업 지원·육성을 위하여 필요한 사항

(2) 문화체육관광부장관은 제1항의 사업을 효율적으로 실시하기 위하여 해마다 기초지방자치단체 중 에서 사업실시 대상지역을 선정하여 기본 3년 동안 지원을 실시하며, 지원에 따른 실적을 매년 평가 하여 평가 결과에 따라 지원을 차등하거나 종료할 수 있다.

(3) 문화체육관광부장관은 제2항의 평가 결과를 반영하여 2년의 범위에서 추가적으로 지원할 수 있다.

6) 관광두레사업의 고유 특성을 반영하는 명칭으로서, 제 48 조제4항제1호, 제 2 호, 제 5 호가 각각 “문화, 체육, 레저 및 산업시설 등의 관광자원화사업", "해양관광의 개발사업 및 자연생태의 관광자원화사업”, "유휴자원 을 활용한 관광자원화사업”임을 고려하여, “주민공동체 기반의 관광자원화사업”을 대안으로 고려할 수 있음

xxxvi 관광두레 법제화 방안 연구 
(4) 제2항과 제3항에 따른 선정 및 평가 기준과 그 밖에 지원에 관하여 필요한 사항은 문화체육관광부 령으로 정한다.

(5) 지방자치단체의 장은 제 2 항의 지역으로 선정되기 전에 해당 지역 내에서 제 1 항 각 호의 사업을 독자적으로 시행하거나 제 2 항과 제 3 항의 지원이 종료된 후 필요한 후속지원을 할 수 있다.

(6) 문화체육관광부장관과 지방자치단체의 장은 주민 주도 관광사업의 추진에 필요한 지원을 하기 위 하여 필요한 경우에는 문화체육관광부령 또는 해당 지방자치단체의 조례로 정하는 기관 중에서 그 지원을 전담하는 조직을 지정하여, 그 조직의 운영 등에 필요한 경비를 지원할 수 있으며 다음 각 호의 업무를 관장하게 할 수 있다.

1. 제1항에 따른 주민사업체 지원 전문인력에 대한 역량 강화, 평가, 활동 지원과 관리

2. 주민사업체의 발굴 및 육성

3. 사업화계획의 수립 지원

4. 주민사업체의 창업과 경영개선 및 파일럿 사업 지원

5. 사업에 대한 모니터링, 평가

6. 주민 주도 지역관광 활성화사업 및 주민사업체 홍보·마케팅 등 사업 총괄 운영

(7) 제1항에 따른 주민사업체 지원 전문인력은 다음 각 호의 업무를 수행한다.

1. 지역 현장에서 주민사업체의 발굴과 조직화, 창업 및 경영개선 지원까지 사업의 총괄 진행

2. 주민사업체와 주민, 지방자치단체와 주민, 고객과 주민, 주민과 주민 사이에서 중간지원 역할의 수행

3. 지역 관광자원의 조사 및 지역의 주민 주도 지역관광 활성화사업 콘셉트 구상

4. 그 밖에 지역 주민사업체 지원·육성을 위하여 필요한 사업

(8) 기초자치단체의 장은 주민 주도 지역관광 활성화사업의 원활한 추진과 진흥을 위하여 전문인력에 대한 사무공간 및 집기 제공과 교육 및 연수의 실시, 주민사업체와의 회의 및 교육 공간의 제공 등 그 활동에 필요한 사항을 지원한다.

(9) 그 밖에 주민사업체 지원·육성 및 효율적 관리 등에 필요한 사항은 문화체육관광부령으로 정한다

2) 관광진흥법 제47조7을 근거로 동법 시행령에 조항 신설(안)

- 관광진흥법 제 47 조의7에서 위임한 사항에 대해서는 41 조의 7 에 위치하는 것 이 바람직함. 현재 법 제 47 조의7이 위임하고 있는 내용을 담은 조문은 동법 시행령 제 41 조의 7 이므로, 현 시행령 제 41 조의 7 부터 제 41 조의 13 은 각각 제 41조의8부터 제 41 조의 14 로 이동해야 함

- 관광두레사업의 내용, 전담조직 운영 등에 대한 근거를 규정함 


\section{「관광진흥법 시행령 일부개정(예시 안)」}

제41조의7(주민 주도의 지역특화 주민사업체 육성·지원 등) (1) 문화체육관광부장관은 법 제47조의7제 5 호에 따라 주민사업체(특정한 지역 주민들의 주체적·자발적·협력적 참여를 바탕으로 문화유적지와 먹을거리, 탐방로, 축제, 숙박시설 등 지역 고유의 자원을 연계·활용함으로써 지역특화 브랜드와 관광 사업을 창출하기 위하여 해당 주민들이 창업하고 그 운영을 주도하는 지역관광 공동체를 말한다. 이 하 같다)의 육성을 위하여 다음 각 호의 행정적·재정적·기술적 지원을 할 수 있다.

1. 주민사업체의 발굴 및 육성 지원

2. 교육 · 홍보 및 정보의 제공

3. 시설 및 유휴공간 지원

4. 주민사업체 지원을 위한 전문인력 선정 및 육성, 평가, 활동비 지원

5. 그 밖에 주민사업체의 활성화 등을 위하여 필요한 사항

(2) 문화체육관광부장관은 주민사업체 육성·지원을 위하여 필요한 경우에는 그 지원을 전담하는 조직 을 지정할 수 있으며, 그 조직의 운영 등에 필요한 경비를 지원할 수 있다.

(3) 문화체육관광부장관은 제 1 항에 따른 지원과 관련하여 필요한 세부 사항을 정하여 고시할 수 있다.

(4) 문화체육관광부장관은 제 1 항 각 호의 사업을 추진하는 지방자치단체의 장에 대하여 필요한 지원 을 할 수 있다.

\section{3) 별도 지원 법률(안)}

- 일반적인 진흥법 체계를 따라 총 17 개 조항으로 구성하며, 관광두레 입법 취 지에 맞춰 전반적인 내용을 포함함

\section{「관광두레 진흥을 위한 지원 법률(예시 안)」}

제1조 (목적) 이 법은 국가 또는 지방자치단체가 주민들이 주도적·협력적으로 지역 고유 자원을 연계. 활용하여 관광 사업을 창업 및 경영개선 하는 데 필요한 사항을 정함으로써 지역관광 활성화와 주민 들의 경제적 이익 보장, 공동체 의식 향상 등 지속가능한 관광 발전을 실현하는 데 목적이 있다.

제2조 (정의) (1) 이 법에서 사용하는 용어의 뜻은 다음과 같다.

1. “관광두레사업”이란 주민의 자발적 참여와 지역자원의 연계·활용을 통한 새로운 방식의 지역관광 발전 모델을 조성하기 위하여 문화체육관광부장관 또는 지방자치단체의 장이 실시하는 제9조 각 호의 사업을 말한다.

2. "주민사업체"란 특정한 지역 주민들의 주체적·자발적·협력적 참여를 바탕으로 문화유적지와 먹을 거리, 탐방로, 축제, 숙박시설 등 지역 고유의 자원을 연계·활용함으로써 지역특화 브랜드와 관광 사업을 창출하기 위하여 해당 주민들이 창업하고 그 운영을 주도하는 지역관광 공동체를 말한다.

(2) 제 1 항에 규정된 것 외의 용어에 관하여는 이 법에서 특별히 정하는 경우를 제외하고는 「관광진흥 법」제2조에 따른 용어의 정의에 따른다.

제3조 (국가 및 지방자치단체의 책무) (1) 국가는 관광두레사업의 지속적·체계적 추진을 위하여 필요한 행·재정적 지원을 실시할 책무를 진다. 


\section{「관광두레 진흥을 위한 지원 법률(예시 안)」}

(2) 지방자치단체는 관광두레사업이 지역관광의 활성화를 촉진하고 주민 주도 관광생태계를 조성할 수 있도록 해당 지역 내 주민사업체에 대하여 필요한 행·재정적 지원을 할 책무를 진다.

제4조 (다른 법률과의 관계) 관광두레사업에 관하여 이 법에서 정한 사항에 대하여는 다른 법률에 우선 하여 이 법을 적용한다.

제 5 조 (관광두레 기본계획 등의 수립) (1) 문화체육관광부장관은 제 1 조의 목적을 달성하기 위하여 제9조 제1항 각 호의 사항이 포함된 관광두레사업 기본계획(이하 “기본계획"이라 한다)을 필요시 관계 중앙 행정기관의 장과 협의하고 지방자치단체의 의견을 들어 5 년 마다 수립하고 이를 지방자치단체의 장에 게 송부하여야 한다.

(2) 지방자치단체의 장은 기본계획의 범위에서 해당 지역에서의 관광두레사업 추진에 필요한 사항에 대하여 해마다 관광두레사업 시행계획(이하 “시행계획”이라 한다)을 수립하고 이를 문화체육관광부장 관에게 제출하여야 한다.

(3) 기본계획 및 시행계획의 수립절차 등에 필요한 사항은 대통령령으로 정한다.

제6조 (실태조사) (1) 문화체육관광부장관은 기본계획과 시행계획을 효율적으로 수립·추진하기 위하여 관광두레사업에 대한 실태조사를 할 수 있다.

(2) 실태조사의 범위와 방법 등 필요한 사항은 대통령령으로 정한다.

제7조 (전담조직) (1) 문화체육관광부장관 또는 지방자치단체의 장은 관광두레사업 지원을 위하여 필요 한 경우에는 대통령령 또는 해당 지방자치단체의 조례로 정하는 기관 중에서 그 지원을 전담하는 조 직을 지정할 수 있으며, 그 조직의 운영 등에 필요한 경비를 지원할 수 있다.

(2) 제1항의 전담조직에 대한 필요한 사항은 대통령령으로 정한다.

제8조 (주민사업체 협의체의 구성) (1) 주민사업체는 관광두레사업의 효율적 추진과 상호 부조 등을 위 하여 협의체를 구성할 수 있다.

(2) 제1항의 협의체의 구성, 운영 및 지원에 관하여 필요한 사항은 대통령령으로 정한다.

제9조 (관광두레사업의 범위 등) (1) 문화체육관광부장관 또는 지방자치단체의 장은 지역관광의 활성화 를 촉진하고 주민 주도 관광생태계를 조성할 수 있도록 각 호의 사항을 지원할 수 있다.

1. 주민사업체 발굴 및 육성 지원

2. 교육·홍보 및 정보의 제공

3. 시설 및 유휴공간 지원

4. 주민사업체 지원을 위한 전문인력 육성 및 활동비 지원

5. 지역자원 활용 콘텐츠 개발

6. 그 밖에 관광두레사업 지원·육성을 위하여 필요한 사항

(2) 문화체육관광부장관 또는 광역 및 기초지방자치단체의 장은 제 1 항의 지원을 함에 있어 상호 간의 역할 배분에 관하여는 대통령령으로 정한다.

제10조 (사업 대상지역 선정 및 평가 등) (1) 문화체육관광부장관은 제8조의 사업을 효율적으로 실시하 기 위하여 해마다 기초지방자치단체 중에서 사업실시 대상지역을 선정하여 3년 동안 지원을 실시하 며, 지원에 따른 실적을 매년 평가하여 평가 결과에 따라 지원을 차등하거나 종료할 수 있다. 


\section{「관광두레 진흥을 위한 지원 법률(예시 안)」}

(2) 문화체육관광부장관은 제 1 항의 평가 결과를 반영하여 2년의 범위에서 추가적으로 지원할 수 있다.

(3) 제 1 항에 따른 선정 및 평가 기준과 그 밖에 지원에 관하여 필요한 사항은 대통령령으로 정한다.

제 11 조 (지방자치단체의 사업) 지방자치단체의 장은 제 10 조제 1 항의 대상 지역으로 선정되기 전에 해당 지역 내에서 제9조제 1 항 각 호의 사업을 독자적으로 시행하거나 제10조제2항의 지원이 종료된 이후 필요한 사항을 조례로 정하는 바에 따라 지원할 수 있다.

제48조의14(주민사업체의 등록 및 취소) (1) 이 법에 따른 지원을 받고자 하는 주민사업체는 문화체육관 광부 장관이 정하는 바에 따라 기초지방자치단체의 장에게 등록하여야 한다.

(2) 기초지방자치단체의 장은 주민사업체가 다음 각 호의 어느 하나에 해당하면 등록을 취소하거나 문화체육관광부 장관이 정하는 바에 따라 일정 기간 이 법에 따른 지원을 중단할 수 있다. 다만 제1호 에 해당하면 그 등록을 취소하여야 한다.

1. 거짓이나 그 밖에 부정한 방법으로 주민사업체 선정 및 등록을 한 때

2. 동일한 내용에 대하여 타 사업비와 중복하여 지원받았을 때

3. 주민사업체의 구성이나 운영 형태 등이 제1항에서 정하는 바에 부합하지 않을 때

4. 주민사업체와 관련하여 관광두레사업 등에 직접·간접적 영향을 미치는 민사 또는 형사 사건이 발 생하였을 때

(3) 기초자치단체의 장은 주민사업체 등록 및 운영현황을 매년 12 월 말까지 문화체육관광부장관과 관할 광역자치단체의 장에게 통지하여야 한다.

제13조 (재정 지원) (1) 국가는 지방자치단체가 관광두레사업을 실시하는 데 필요한 재원을 보조금으로 지원할 수 있다.

(2) 국가는 관광진흥개발기금법에 따른 관광진흥개발기금의 재원으로 관광두레사업을 실시하는 데 필 요한 지원을 할 수 있다.

제14조 (관광두레 관련 교육·홍보 및 정보의 제공) 문화체육관광부장관 또는 지방자치단체의 장은 관광 두레사업의 시행과 주민사업체에 대한 지원을 위하여 대통령령으로 정하는 바에 따라 교육, 홍보를 실시하거나 관련 정보를 제공할 수 있다.

제15조 (국·공유재산의 대부 등) 문화체육관광부장관 또는 지방자치단체의 장은 주민사업체 또는 제7 조의 전담조직과 제8조의 주민사업체 협의체에 대하여 국유재산 또는 공유재산을 대통령령으로 정하 는 바에 따라 대부하거나 사용 수익하게 할 수 있으며 대부료나 사용료를 경감할 수 있다.

제16조 (관광두레 육성·지원을 위한 전문인력 양성) 문화체육관광부장관 또는 지방자치단체의 장은 관 광두레 지원·육성을 위하여 대통령령으로 정하는 바에 따라 전문인력을 발굴·양성 및 평가하고 그 활동을 지원할 수 있다.

제17조 (권한의 위탁) 문화체육관광부장관 또는 지방자치단체의 장은 제8조제1항 각호의 지원 업무에 관한 권한의 전부 또는 일부를 대통령령으로 정하는 바에 따라 제6조의 전담조직에 위탁할 수 있다. 


\section{5. 결론 및 제언}

\section{가. 연구 결과 요약}

- 관광두레사업은 2013년부터 문화체육관광부의 정책 사업으로 추진되어 왔으 며, 주민 주도형 관광 사업을 활성화함으로써 주민들이 일자리와 소득 등 지역 관광 활성화로 인한 실질적 혜택을 받을 수 있도록 함

- 관광두레사업은 주민공동체가 지역자원을 활용해 주체적·자발적·협력적으로 관광사업체를 창업 및 경영개선 하도록 돕는 새로운 지역관광 활성화 모델로 전 문인력(관광두레 $\mathrm{PD}$ )을 양성하여 단계별·맞춤형으로 지원하도록 사업 방식을 설계한 것이 큰 특징임

- 2019 년까지 480 개 주민공동체를 발굴하고, 110 개가 창업 및 경영 개선을 완 료해 주민들이 직접 만들고 경영하는 다양한 관광사업체를 창출함. 또한 주민 사업체를 통해 일자리를 만들고 지역 내 소득을 올리는 등 지역 경제 활성화 효과를 냄. 관광두레 $\mathrm{PD}$, 지역주민들의 역량을 강화하여 관광주체로 육성하고 지역주민들의 자발적 참여와 협력에 대한 인식 제고 및 정책 패러다임 변화를 선도하는 등의 성과를 나타냄

- 이러한 성과에도 불구하고 그동안 사업 지침에 의거해 사업을 운영하다보니, 추진 과정에서 명확한 법적 근거 부재에 따른 한계가 발생함

- 1 차 년도에는 관광두레사업의 원활한 추진 기반이라고 할 수 있는 관광두레사 랑방 지원 약속이 이행되지 않거나, 지방자치단체의 이해 및 관심이 부족함 - 1 3차년 주민사업체 육성 단계에서는 지방자치단체의 행·재정적 지원과 협력 유도, 유휴공간을 활용해 관광두레 주민사업체의 창업을 촉진하거나 공공 관광시설을 연계·활용하는 데 한계가 있음

- 4 5차년 및 사후 관리 단계에는 지방자치단체가 예산을 매칭하고, 중간지 원조직을 운영 및 지원하는 데 어려움이 있음

- 관광두레사업의 법제화 필요성에 대해 관광두레 $\mathrm{PD}$, 지방자치단체 관계자, 지 역주민 등은 높은 공감을 표시함. 특히 지방자치단체의 지원 및 협력, 지역 관 광자원 및 유휴공간 활용, 주민사업체 관리, 주민 주도 관광사업의 확장과 지 
속성, 그리고 안정적인 사업 추진을 위해 근거 법령 필요성을 제기함

- 법제화 대안으로 관광진흥법 내 조항을 신설하는 안, 관광진흥법 제 47 조의7 을 근거로 동법 시행령에 조항을 신설하는 안, 별도 법률을 제정하는 안을 제 시함. 입법편의성을 고려하면 관광진흥법 시행령 내 조문 신설과 관광진흥법 내 조문 신설이 현실적이며 입법 효과성 측면에서는 별도 법률을 제정하는 안 이 가장 바람직함

- 본 연구에서는 별도 법률을 제정하는 것을 기준으로 조문과 입법 취지를 기술함. 관광두레사업의 제도적·체계적 발전 관점에서 핵심 조문을 구별하여, 관광진흥 법 또는 동법 시행령에 조항을 신설하는 방안에 대해 조문(예시 안)을 제시함 - 중간지원조직 운영(전담 조직), 관광두레PD 양성 및 활동 지원·평가(전문인 력), 지방자치단체 협력 및 주민 주도 관광사업 육성-지원 근거, 주민사업체 관리(주민사업체 등록 및 취소), 국·공유재산에 대한 특례 등을 포함함

\section{나. 본 연구의 의의}

- 본 연구는 관광두레사업이 그간 창출해 온 성과를 정리하고, 사업 추진 과정에 서 관광두레 $\mathrm{PD}$, 주민사업체, 지방자치단체 담당자 등이 명확한 근거 법 부재로 인해 겪은 현장의 어려움을 수렴해 법제화 방안을 제시했다는 데 의의가 있음

- 지속가능한 관광 발전을 위해서는 주민 주도의 관광사업 육성이 무엇보다 중 요하며, 주민 주도형 정책 추진은 시대적 흐름임. 본 연구 결과는 주민 주도 지역관광 활성화 정책의 제도적 추진 기반을 위한 기초자료로서 의의가 있음

- 본 연구에서는 법제화 대안별 입법 과정의 편의성과 입법 결과의 효과성을 검 토하고, 각 대안별 예시(안)를 제시함으로써 별도 법률 제정 및 관광진흥법 일 부개정 추진 과정에서 실체적 활용이 가능함. 다만 입법 상황에 맞춰 조문 구 성과 내용 등에 대해 별도의 검토가 필요함

- 2020 년은 관광두레사업의 총괄지원기관이 한국문화관광연구원에서 한국관광 공사로 변경되는 등의 과도기적 상황으로, 본 연구에서는 시행규칙이나 지침 단위에서 다뤄야 하는 구체적인 기준이나 요건 등에 대해서는 다루지 않음 


\section{다. 제언}

- 관광두레 법제화는 법적 근거를 가지고 정부의 예산과 역량을 지원하는 '지 원', '진흥' 성격으로 지나치게 세부적으로 구체적인 사항을 법령에 규정하면, 사업 운영의 유연성과 효율성을 확보하기 어려울 수 있음. 그럼에도 관광두레 사업의 고유 특성과 추진 체계를 안정화하기 위한 법적 근거 등 핵심적인 사항 에 대해서는 명확하고 구체적으로 법제화해야 함

- 관광두레사업 총괄지원기관이 2020년부터 한국관광공사로 변경되면서 사업 추진 체계와 지원 방식 등에서 이전과 차이를 보이고 있음. 관광두레사업의 성과를 보다 확장 및 지속가능하기 위해서는 체계적·제도적으로 안정된 시스 템을 운영할 수 있는 별도 지원기관의 설립을 검토할 필요가 있음

- 주민 주도 관광사업을 통한 지속가능한 지역관광 활성화와 일자리 창출, 주민 소득 증대 등은 단발적인 정책으로 목적을 달성하기 어려움. 관광두레 법제화 를 토대로 안정적인 정책으로 발전해 갈 수 있도록 중앙정부의 지속적인 관심 과 노력이 필요함

- 현행 관광두레사업은 정책 추진 방식이 하향식 지원체계로 되어 있어 중앙정 부에서 주민 주도 관광사업이라는 방향성과 마중물을 제시하고, 지방정부와 민간이 자생적으로 관련 사업을 추진할 수 있도록 지속적 성장.발전 기반을 마련해야 함

- 중장기적으로는 주민 주도, 주민공동체 기반의 관광 사업 육성·지원에 관한 법 률을 별도 신설하는 등 법률적 뒷받침이 이루어질 필요가 있음. 또는 지역관광 육성을 위한 제도적 기반으로서 (가칭)지역관광진흥법을 제정하고 여기에 지역 관광 전담조직과 주민사업체 육성 및 지원에 관한 사항을 포함할 수도 있음

- 마지막으로 법제화 연구에서 그치지 않고 실제 법령 정비가 이루어지기 위해 서는 주관부처인 문화체육관광부의 관심과 노력이 무엇보다 중요함 



\section{목차}

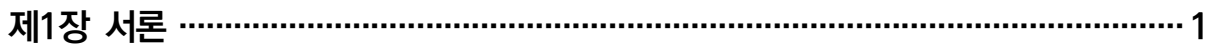

제1절 연구 배경 및 목적 3

1. 연구 배경 3

2. 연구 목적 5

제2절 연구 범위 및 체계 6

1. 연구 범위 6

2. 연구 체계 7

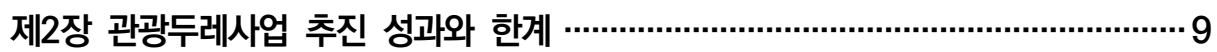

제1절 관광두레사업의 추진 성과 11

1. 관광두레사업의 추진 현황 11

2. 관광두레사업의 성과 22

제2절 관광두레사업의 한계 30

1. 심층조사 개요 30

2. 추진 과정상 한계점 31

3. 법제화 필요성에 대한 인식 36

제3절 시사점 42

제3장 관광두레사업 관련 법령 및 유사 사례 분석 …………………………….....45

제1절 관광두레사업 관련 법령 47

1. 관광진흥법 47

2. 지방자치단체 조례 53

$\begin{array}{ll}\text { 제2절 유사 사례 } & 60\end{array}$

1. 마을기업육성지원법(안) 제정 필요성 60

2. 마을기업육성지원법(안) 주요 내용 64 
제3절 시사점

제4장 관광두레사업 법제화 방안 ………......................................................... 71

제1절 법제화 필요성 $\quad 73$

1. 관광두레 법제화 필요성 73

2. 관광두레 법제화 기대효과 75

제2절 법제화 방향 및 범위 $\quad 77$

1. 법제화 방향 77

2. 법제화 범위 및 내용 82

제3절 법제화 방안 $\quad 97$

1. 관광진흥법 내 조항 신설(안) 97

2. 관광진흥법 제47조의7을 근거로 동법 시행령에 조항 신설(안) 104

3. 별도 지원 법률(안) 106

제5장 결론 및 제언 …................................................................................. 111

$\begin{array}{ll}\text { 제1절 결론 } & 113\end{array}$

제2절 제언 116

참고문헌 / 119

ABSTRACT / 121 


\section{표 목차}

〈표 2-1〉 관광두레사업 추진 주체별 역할 14

〈표 2-2〉 관광두레사업 연도별 추진 실적 19

〈표 2-3〉 2019년 관광두레사업 대상지 현황(2020년4월 말 기준) 20

〈표 2-4〉 주민사업체 누적 매출액 24

〈표 3-1〉 관광진흥법 제48조 하위 조항 내용 50

〈표 3-2〉 마을기업육성사업의 법제화 추진 과정 65

〈표 3-3〉 마을기업육성지원법안 구조 $\quad 67$

〈표 4-1〉 법제화 대안별 고려사항 81

〈표 4-2〉 별도 법률 제정 시 장·절 체계(안) 83

〈표 4-3〉 관광진흥법 일부 개정 시 반영사항 85 


\section{그림 목차}

[그림 1-1] 연구 수행 체계 8

[그림 2-1] 관광두레사업 추진 체계 14

[그림 2-2] 관광두레사업을 통한 주민들의 인식 변화 27

[그림 3-1] 관광진흥법 분법화(안) 49 
관광두레 법제화 방안 연구

\section{제1장}

서론 



\section{제1절 연구 배경 및 목적}

\section{1. 연구 배경}

\section{가. 관광두레사업의 성과를 지속적으로 창출하기 위한 방안 모색}

- 관광두레사업은 2013 년부터 시행한 문화체육관광부의 정책 사업으로서, 지역 주민공동체가 주도하여 지역자원을 활용한 관광 사업을 창업 및 경영 개선할 수 있도록 육성하는 데 목적을 둠(박주영, 2020).

- 주민공동체가 지역자원을 활용한 다양한 관광 사업을 경영하고, 관광객이 이러한 상품을 소비함으로써 지역 내에 관광객의 소비가 순환해 지역경제 가 활성화 되는 것을 목표로 함

- 단계적인 지역 확대 및 주민공동체 발굴 노력으로 2019 년까지 480개 주민공 동체를 발굴·육성하였고, 이 가운데 110 개가 관광객을 대상으로 상품과 서비 스를 판매하는 사업체로 창업 및 경영개선을 완료함1)(박주영, 2020). 2019년 관광두레사업을 통한 일자리 수는 850 명으로 집계되는 등 관광두레사업이 지 역 내 일자리 창출 및 경제 활성화 효과를 견인하는 것으로 평가됨(문화체육관 광부, 2020).

- 문재인 정부의 국정과제에 “관광을 통한 지역 균형발전과 지역경제 활성화”를 위해 관광두레 주민공동체를 2022년까지 1,125 개 발굴하는 것으로 상정되었 고, 이를 토대로 관광두레사업의 예산 및 대상지역 규모가 계속 확대되는 등 관광두레사업의 성과를 지속적으로 창출하기 위한 방안 모색이 필요한 시점임

1) 창업의 기준은 법인격 설립뿐 아니라 관광 상품과 서비스의 개발을 통해 관광객을 대상으로 판매가 이루어 지는 경우를 의미함 
- 2013년 5개 기초지자체, 총 사업비 5억 원에서 시작하여 2019년 46개 기 초지자체, 총 사업비 80 억 원으로 규모가 확대됨

\section{나. 직접적인 근거 법령 부재로 인해 사업의 안정적 확대와 발전에 어려움}

- 그동안 관광두레사업은 「관광진흥법」 제 47 조의7(관광산업 진흥 산업) 및 제 48 조(관광 홍보 및 관광자원 개발)에 근거해 추진됨. 하지만 해당 조항에 '관광두 레'라는 사업명이나 '주민 주도 관광사업'과 같이 관광두레사업의 고유 성격을 나타낸 표현이 존재하지 않아 직접적인 법적 근거가 부족하다고 인식되어 옴

- 관광두레사업이 소기의 목적을 달성하기 위해서는 중앙과 지방자치단체를 비 롯해 지역 내 다양한 조직, 주체들 간의 유기적 협력이 무엇보다 중요함. 하지 만 명확한 법적 기반 부족으로 인해 협력 체계를 갖추는 데 한계가 있음

- 특히 다른 정책사업과 달리 지방자치단체가 사업 예산을 집행하지 않을 뿐만 아니라 관광두레사업에 대한 직접적인 근거 법령이 부재하여 지방자치단체 차 원에서 관광두레 주민사업체와 관광두레 $\mathrm{PD}$ 에 대한 지원 방안을 마련하기 어 려운 상황임(박주영, 2020). 또한 관광두레사업 지원이 종료된 이후, 지방자 치단체 자체적으로 주민 주도의 관광 사업 지원을 지속하고자 할 때 관련 법적 기반 부재로 어려움이 있음

- 직접적인 근거 법령 부재로 인해 사업 추진 현장에서 발생하는 애로사항뿐 아 니라 사업의 안정적 확대와 발전을 위한 추진 체계 구축을 위해 법제화 필요성 이 지속 제기되어 왔음에도 불구하고, 실체적 구현을 위한 법제화 연구와 노력 은 이루어지지 않음

\section{다. 주민 주도 지역관광 활성화를 위한 법적 기반 필요}

- 관광두레사업은 기존 관광개발이 관 주도, 물리적 시설 조성 중심이라는 한계 를 개선하고 지역주민이 주도적-협력적으로 지역 자원을 활용해 관광 사업을 창업 및 경영 개선할 수 있도록 육성함으로써 주민 소득 향상, 일자리 창출, 공동체 의식 향상 등의 성과를 거둬 옴. 관광두레사업의 이러한 성과를 토대로 
주민 주도 및 사람 중심 정책의 중요성, 소프트웨어 및 휴먼웨어 지원 필요성 등이 중요한 정책 화두로 대두됨

- 2013년부터 한국문화관광연구원이 해당 사업을 총괄지원 해 왔으며, 2020년 에 한국관광공사가 새롭게 총괄지원을 담당하게 됨. 그동안 관광두레사업은 지역관광의 새로운 발전 모델을 지향하고 사업 내용과 방식을 개선·발전시켜 온 바, 고유의 특성을 살려 당초 목적대로 사업이 안정적·체계적으로 추진되 기 위해서는 법적 기반을 마련할 필요가 있음

\section{2. 연구 목적}

- 본 연구는 관광두레사업의 안정적 확대와 발전을 위해 직접적인 근거 법령을 마련하는 데 목적이 있음

- 관광두레사업은 지속가능한 관광 정책의 실천적 해법으로서, 주민이 주도하 는 지역관광 활성화를 꾀함

- 이러한 정책의 안정적 추진을 위하여 문화체육관광부 장관과 지방자치단체 장이 주민 주도형 지역관광 활성화사업을 추진할 수 있도록 근거 규정을 만 들고 지원 체계를 공고히 하고자 함

- 구체적으로 본 연구는 관광두레사업의 추진 현황과 성과를 토대로 근거 법령 부재에 따른 한계를 도출하고, 유사 법령 사례 분석을 바탕으로 관광두레 법제 화 방안을 도출하는 데 목적이 있음 


\section{제2절 연구 범위 및 체계}

\section{1. 연구 범위}

\section{가. 시간적 범위}

- 관광두레사업의 사업기간을 고려해 2013년7월부터 2020년4월까지를 시간적 범위로 함

- 2013년 관광두레사업부터 2019년 관광두레사업까지를 대상으로 함2)

\section{나. 공간적 범위}

- 관광두레사업은 기초지방자치단체를 대상으로 추진하며, 매년 공모를 통해 신 규 사업대상지역을 선정함. 관광두레사업 대상지역으로 선정된 기초지방자치 단체를 연구 범위로 함

\section{다. 내용적 범위}

- 연구의 내용적 범위는 연구 논리에 따라 크게 네 가지로 구분함

- 첫째, 관광두레사업 추진 성과와 한계

- 관광두레사업 추진 성과

- 관광두레사업 추진 과정에서 나타난 근거 법령 부재에 따른 한계

- 이해관계자 심층 조사

2) 2013년 사업기간: 2013년7월 2014년1월, 2014년 사업기간: 2014년2월 2015년2월, 2015년 사업기 간: 2015년3월 2016년2월, 2016년 사업기간: 2016년3월 2017년2월, 2017년 사업기간: 2017년3 월 2018년3월, 2018년 사업기간: 2018년4월 2019년4월, 2019년 사업기간: 2019년4월 2020년4월 
- 둘째, 관광두레사업 관련 법령 및 유사 사례 분석

- 관광진흥법 내 관광두레사업 관련 조항 분석

- 관광두레사업 관련 지방자치단체 조례 현황

- 관광두레사업과 유사성이 있는 정책사업의 입법 과정 분석

- 셋째, 관광두레사업 법제화 방안

- 관광두레사업 법제화 필요성

- 법제화 기본 방향

- 관광진흥법 및 시행령 개정(예시 안), 별도 법률 제정(예시 안)

- 넷째, 결론 및 제언

- 관광두레사업의 발전을 위해 법제화 관점에서 장기적으로 고려할 사항 제시

\section{2. 연구 체계}

\section{가. 연구 방법}

- 문헌연구 및 2 차 자료 분석

- 문헌연구 및 2 차 자료를 바탕으로 관광두레 사업 법제화의 필요성 및 법제 화 방향 제시

- 법령 조사·연구

- 현행 관련 법령 조사

- 유사한 정책 사업 여건 및 과정을 분석하여 관련 절차와 조치 내용 등을 분석

- 이해관계자 심층인터뷰

- 관광두레사업을 추진 및 담당하는 관광두레 $\mathrm{PD}$, 지자체 관계자 및 주민사업 체 대상 심층인터뷰

- 전문가 회의 및 자문

- 새로운 법률 조항 마련을 위한 전문가 회의 및 자문 


\section{나. 연구 수행 체계}

- 본 연구는 연구 논리에 따라 다섯 개의 장으로 구성하였으며, 각 장의 주요 내용과 구체적 연구 방법은 [그림 1-1]과 같음

[그림 1-1] 연구 수행 체계

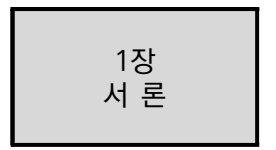

2장

관광두레사업

추진 성과와

한계
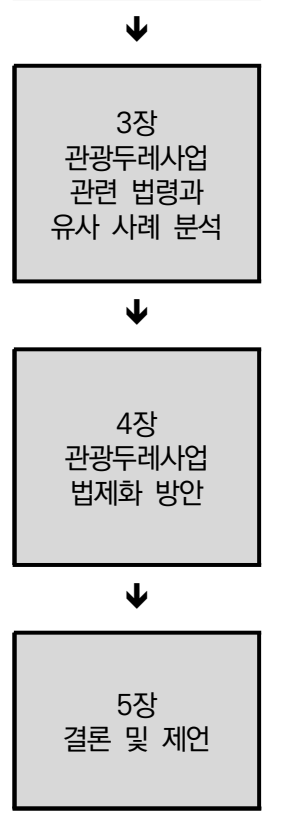

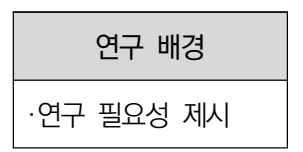

관광두레사업 추진 성과

·관광두레사업의 특징

·추진 현황과 성과

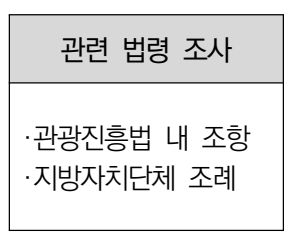

법제화 필요성

·현행 법제도적 한계 ·관광두레 안정적 발전 기반 구축

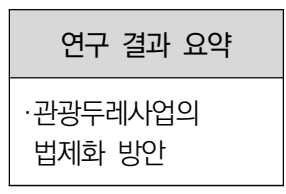

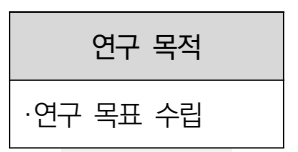

연구범위 및 체계

-연구 틀 마련

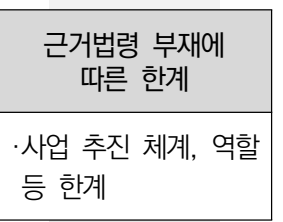

이해관계자 심층인터뷰

·근거법령 부재에 따른 애로사항 도출
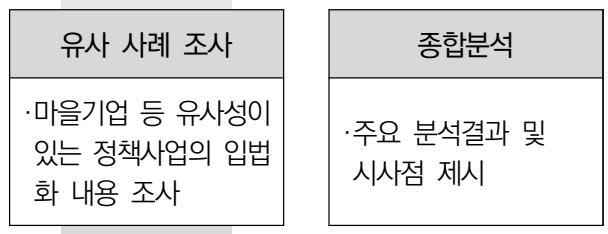

법제화 범위 및 내용

·법제화 범위

·조문 내용 및 입법

취지

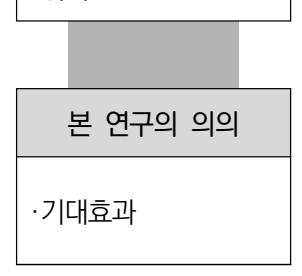

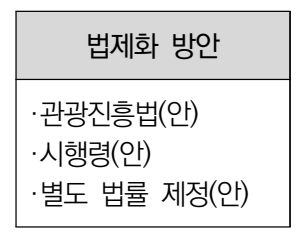

\begin{tabular}{|c|}
\hline 제언 \\
\hline $\begin{array}{l}\text { ·향후 법제화 추진 } \\
\text { 방향 }\end{array}$ \\
\hline
\end{tabular}


관광두레 법제화 방안 연구

제2장

관광두레사업

추진 성과와 한계 



\section{제1절 관광두레사업의 추진 성과}

\section{1. 관광두레사업의 추진 현황}

\section{1. 관광두레사업의 배경}

\section{가. 지역 경제를 활성화 시키는 주민주도 관광사업 창출 필요}

- 과거 다수의 관광개발 정책 사업은 시설을 짓고, 지역을 방문하는 관광객 수를 늘리는 데에 목표를 둠. 여기에는 관광객 수가 증가하면 지역 내 소비가 늘어 지역 경제가 활성화될 것이라는 가정이 내재돼 있음. 하지만 관광객 수 증가가 반드시 지역 경제 활성화로 이어질 것이라고 담보하기 어려움

- 관광객들의 소비가 지역 내 순환되어 일자리 증가와 주민 소득 창출 등 긍정 적인 효과를 거두기 위해서는 주민주도의 관광 사업이 만들어지고, 관광객들 이 이러한 상품과 서비스를 구매해야 함. 요컨대 시설 조성보다 지역 내 여러 자원을 엮어 효과적으로 경영하도록 할 것인가, 주민들이 다양한 관광 사업을 창출할 수 있도록 할 것인가에 대해 관심을 둠

\section{나. 지역사회, 주민공동체를 지속가능한 관광의 핵심 요소로 인식}

- 전통적 관광 관점에서는 관광객이 만족하고, 관광자원이 보호되고, 관광산업이 수익을 얻으면 결과적으로 지역사회가 발전한다고 생각함. 하지만 지속가능한 관광에 대한 인식이 확대되면서, 관광이 지속가능하려면 관광객, 관광자원, 관 광산업과 더불어 지역사회를 핵심 요소로 고려해야 한다는 공감대를 형성함

- 관광으로 인한 편익과 성과가 지역사회에 확산되고 관광을 통한 발전이 이루 어져야 관광이 지속가능함 


\section{다. 지역주민을 관광사업 주체로 육성}

- 관광두레사업은 지역관광 정책의 패러다임을 '비즈니스 창출' 중심으로 바꾸 고, '지속가능한 관광'을 실천할 해법으로서, 지역주민 공동체를 관광사업 주체 로 육성하는 지원 체계를 제시함(문화체육관광부, 한국문화관광연구원, 2020)

- '관광두레'는 이러한 방향성을 담아 '관광'과 '두레'를 조합해 명명함. 즉, 지역 주민들이 주체적·자발적·협력적으로 관광사업을 운영하여 일자리와 수익을 창출하는 것을 지향함

- 주민공동체가 관광객의 필요를 파악해 상품과 서비스를 개발하도록 하고, 지역자원을 활용하도록 하여 상품과 서비스의 판매로 인한 수익이 지역 내

에서 순환할 수 있도록 함

- 또한 관광두레사업으로 인한 지원이 종료된 뒤에도 자립적으로 경영할 수 있도록 하기 위해 직접적인 자금 지원이 아니라 사업 역량을 강화할 수 있 도록 교육·멘토링 등을 지원함

\section{2. 관광두레사업의 목적과 주요 용어의 정의}

\section{가. 관광두레사업의 목적}

- 첫째, 주민 주도의 관광사업체 창업 및 육성 지원

- 지역주민이 주도·협력하여 지역을 방문하는 관광객을 대상으로 숙박, 식음, 주민여행, 체험, 기념품 등의 관광사업을 경영하는 관광사업체를 성공 창업 하고 자립 발전하도록 지원함

- 둘째, 관광두레 형성을 통한 공동체 의식 제고 및 지역관광 활성화 - 주민이 경영하는 관광사업체 간 두레(네트워크)를 형성하여 공동체 의식을 함양하고 경쟁력을 높임으로써 지속 성장을 유도함

\section{나. 주요 개념}

- '관광두레'는 주민의 자발적 참여와 지역자원의 연계·활용을 통한 새로운 방 식의 지역관광발전 모델을 의미함 
- 지역주민의 주체적·자발적·협력적 참여와 지역자원의 연계가 핵심적 요소임

- '관광두레 주민사업체'는 관광두레 사업 대상지역(시·군·구)에서 발굴·육성하 는 관광사업 주민공동체를 의미함

- 지역 내 자원의 발굴·운영에 참여하여 가치 공유를 기반으로 지역특화 관광 사업을 경영하는 조직을 뜻함(박주영 등, 2013)

\section{3. 관광두레사업의 추진 체계}

\section{가. 관광두레사업의 추진 주체와 역할}

- 관광두레사업의 추진 주체는 문화체육관광부, 중앙 지원기관(한국문화관광연 구원, 한국관광공사), 지방자치단체(사업 대상지역), 관광두레프로듀서(이하, 관광두레PD), 전문가(멘토), 지역주민임3)

- 문화체육관광부는 기본계획 수립과 재정 지원을 맡음

- 중앙 지원기관에서 관광두레PD의 활동 지원과 관리, 주민공동체의 발굴과 육성(사업화 계획 수립 지원, 멘토링, 역량 강화, 창업과 경영개선 파일럿사 업 지원 등), 사업 모니터링, 평가, 홍보·마케팅 등을 담당함

- 지방자치단체는 관광두레 사랑방 제공, 주민사업체 발굴 지원, 지역자원 연 계 지원 등을 담당함

- 관광두레PD는 지역에서 주민공동체를 발굴해 주민사업체(관광두레기업)로 육성하는 역할을 맡음

- 전문가(멘토)는 지역주민들이 관광 수요에 부합하며 지역자원을 활용해 매 력적인 관광상품과 서비스를 개발할 수 있도록 주민 역량 강화를 지원함

- 지역주민은 관광두레사업의 실질적 주체로서, 관광두레사업 참여를 통해 관 광사업체를 창업 또는 경영 개선함

3) 2013년 관광두레사업부터 2019년 관광두레사업까지는 한국문화관광연구원이 관광두레사업의 총괄 운영 을 담당하고, 한국관광공사는 홍보·마케팅 지원만 담당하였으나, 2020년 관광두레사업부터 한국관광공사 가 사업 전체를 총괄 지원함 
〈표 2-1〉 관광두레사업 추진 주체별 역할

\begin{tabular}{|c|c|c|}
\hline \multicolumn{2}{|c|}{ 주체 } & 역할 \\
\hline \multicolumn{2}{|c|}{ 문화체육관광부 } & - 기본계획 수립, 재정 지원 \\
\hline \multirow[t]{2}{*}{$\begin{array}{l}\text { 중앙 } \\
\text { 지원기관 }\end{array}$} & $\begin{array}{l}\text { 한국문화 } \\
\text { 관광연구원 }\end{array}$ & $\begin{array}{l}\text { - 관광두레PD 활동 지원과 관리, 주민공동체 발굴과 육성(사업화 계획 수립 지 } \\
\text { 원, 멘토링, 역량 강화, 창업과 경영개선 파일럿사업 지원 등), 사업 모니터링, } \\
\text { 평가, 홍보·마케팅 등 사업 추진 총괄 }\end{array}$ \\
\hline & 한국관광공사 & · 홍보·마케팅 \\
\hline \multicolumn{2}{|c|}{ 지방자치단체 } & - 관광두레 사랑방 제공, 주민사업체 발굴 지원, 지역자원 연계 지원 등 \\
\hline \multicolumn{2}{|c|}{ 관광두레PD } & $\begin{array}{l}\text { - 관광두레사업 추진 주체들 사이에서 중간 지원 역할을 하는 기획자, 활동가 } \\
\text { - 주민공동체를 발굴하여 사업화 계획을 수립하고 주민사업체로서 법인격을 갖춰 } \\
\text { 창업에 이르는 전 과정을 밀착 지원 }\end{array}$ \\
\hline \multicolumn{2}{|c|}{ 전문가(멘토) } & $\begin{array}{l}\text { - 지역주민들이 관광 수요에 부합하며 지역자원을 활용해 매력적인 관광 상품과 } \\
\text { 서비스를 개발할 수 있도록 주민 역량 강화 지원 }\end{array}$ \\
\hline \multicolumn{2}{|c|}{ 지역주민 } & $\begin{array}{l}\text { - 관광두레사업의 실질적 주체 } \\
\text { • 관광두레사업 참여를 통해 주민사업체를 창업 또는 경영 개선 }\end{array}$ \\
\hline
\end{tabular}

[그림 2-1] 관광두레사업 추진 체계

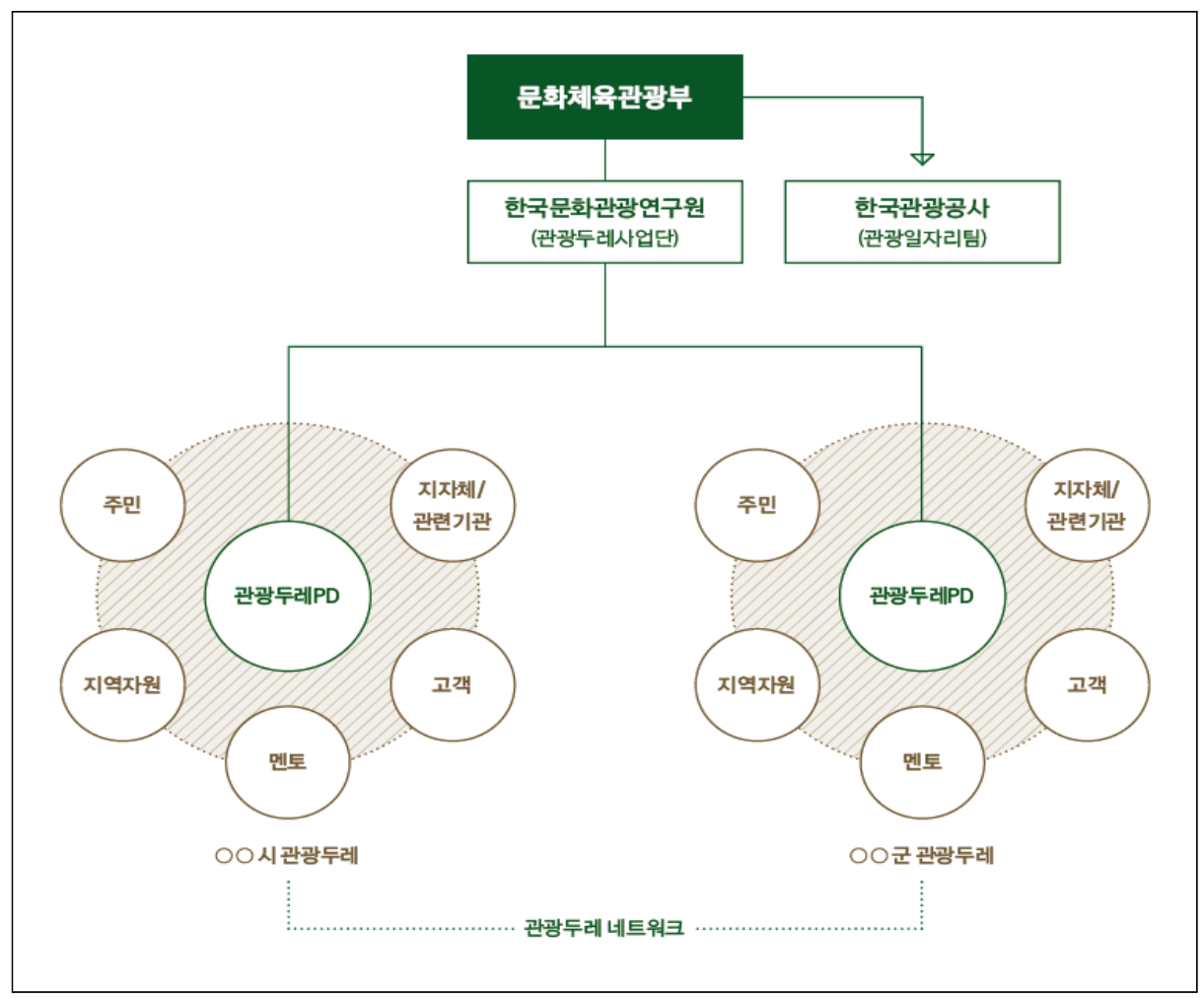

주: 본 연구의 시간적 범위인 2013년8월부터 2020년4월까지의 사업 추진 체계도임. 현재는 사업의 총괄 지원을 한국관 광공사에서 단독 수행함 
- 다른 정책사업과 달리 문화체육관광부의 재정이 지방자치단체를 거치지 않고, 총괄지원기관이 관광두레 PD 활동비와 지역주민 역량 강화 비용을 지원한다 는 데 특징이 있음

- 주민 역량 강화 비용도 주민들에게 직접 예산을 지원하는 게 아니라, 관광 두레PD와 지역주민이 수립한 역량 강화 계획에 따라 총괄지원기관이 소요 비용을 집행하는 간접 지원 방식임

\section{나. 지역 관광두레사업 총괄, 관광두레PD}

- 관광두레사업의 주요 특징이자 핵심 주체가 관광두레 $\mathrm{PD}$ 임. 관광두레 $\mathrm{PD}$ 는 지 역 관광두레사업을 총괄함. 지역 현장에서 주민공동체를 발굴해 조직화하며, 주민공동체가 관광사업 계획을 수립해 상품과 서비스를 개발하고 사업체로서 법인격을 갖춰 실제 창업에 이르기까지 전 과정을 밀착 지원함

- 지역주민을 대상으로 단계별·맞춤형 현장 밀착 지원을 함으로써 주민사업체 육성 지원이 종료된 뒤에도 해당 사업체가 자생력을 갖고 지속 경영을 할 수 있도록 하는 데에 관광두레PD가 주요한 역할을 함

- 관광두레 $\mathrm{PD}$ 는 관광두레사업의 총괄지원기관과 주민, 지방자치단체와 주민, 전문 가와 주민, 주민과 주민 사이에서 중간 지원 역할을 하는 기획자이며, 활동가임

\section{다. 관광두레사업 대상지역 및 관광두레PD 선발}

- 관광두레사업은 시·군·구 기초지방자치단체를 대상지역으로 선정하며, 매년 공모를 통해 선정함. 다만 관광두레 $\mathrm{PD}$ 가 사업 추진에 핵심 역할을 수행하기 때문에, 지역의 특성보다는 관광두레 $\mathrm{PD}$ 로서 활동하기 적합한 인재 유무가 사 업 대상지역 선발에 관건으로 작용함

- 사업 대상지역 및 관광두레PD 선발 시, 서류전형에서 기초지방자치단체의 사업협력계획서와 해당 지역을 대상으로 활동할 관광두레 $\mathrm{PD}$ 후보자의 활 동계획서를 심사할 때 각각의 평가 점수 비중을 20 대 80으로 반영하는 것 도 이 같은 맥락 때문임 
- 서류전형에서 합격한 관광두레PD 후보자 대상으로 면접·워크솝을 진행하며, 최종 합격한 관광두레PD가 활동하는 지역이 관광두레사업 대상지역이 됨4)

- 지방자치단체는 관광두레사업 공모에 참여할 때, 협력계획서를 제출하는 데 여기에는 관광두레사업 추진 필요성, 관광두레 PD 활동 공간 및 기자재 제공 협력, 사업의 원활한 추진을 위한 협력 계획을 기재하도록 함

\section{라. 관광두레 주민사업체}

- 관광두레사업은 지역관광의 문제 혹은 지역의 문제를 관광사업으로 해결하고 자 하는 주민공동체가 주민사업체로서 창업 혹은 경영 개선할 수 있도록 육성 함. 이 때 주민공동체는 사업 대상지역인 시·군·구 공간 범위에서 같은 뜻을 가진 공동체를 의미함

- 관광두레사업의 주민공동체는 공동의 목표를 지향하는 공동체를 의미함. 반 드시 같은 마을에 거주하는 주민으로 구성할 필요는 없음

\section{4. 관광두레사업의 세부 사업 내용}

\section{가. 사업 기간 및 연차별 목표}

- 관광두레사업 대상지역으로 선정되면 연차별 목표에 따라 기본적으로 3년 간 사업이 추진됨. 종합평가를 통해 관광두레사업 우수 모델로 성장 가능성이 있 는 지역을 선정해 2 년을 추가 지원함

- 즉 관광두레사업을 통한 지원 기간은 기본 3년, 최대 5년임

- 3 년간의 지원·육성을 통해 관광사업체로서 자립하는 것을 목표로 함. 1 차 년 도에는 주민사업체를 발굴하고 주민 참여 워크숍을 통해 사업계획서를 작성 함. 2차 년도에는 사업계획서를 기초로 필요한 역량을 강화하고 파일럿 사업 을 시행해 창업과 경영 개선을 완료함. 3차 년도에는 주민사업체 간 연계 협력

4) 공모 시 관광두레PD 후보자가 활동할 지역을 기재하도록 하며, 서류전형에서 해당 지역 거주자를 우대함. 지역에 대한 이해와 애정이 높고, 그동안의 지역 활동 경험을 통해 중간지원자로서 역할을 할 것으로 기대 하기 때문임 
을 통해 관광두레 생태계를 구축해 안정적인 성장 기반을 마련함

- 4 5차년에는 주민사업체가 경영 다각화와 수익 확대를 통해 지속 성장할 수 있 도록 경영 고도화 지원, 홍보·마케팅 강화 등을 지원함. 특히 사업성 강화를 통해 경쟁력을 제고하고, 개별 주민사업체의 육성이 아니라 다른 관광사업체와 지역 자원을 연계해 관광 상품과 서비스를 제공하는 체계를 마련하는 데 주안점을 둠

\section{나. 사업 추진 내용5)}

- 관광두레사업은 크게 1) 관광두레PD 선발과 역량 강화, 2) 주민사업체 발굴과 사업 계획 수립 지원, 3) 주민사업체 창업과 경영 개선 지원, 4) 연계 통합 프 로그램 운영, 5) 홍보·마케팅으로 나뉨

- 관광두레PD 선발과 역량 강화

- 관광두레PD가 관광두레사업 취지에 맞게 주민사업체를 육성해 낼 수 있도 록 활동비를 지원하며, $\mathrm{PD}$ 로서 필요한 역량을 갖출 수 있도록 다양한 교 육·훈련 프로그램을 제공함

- 관광두레PD가 지역 여건에 맞춰 주민사업체와 지역 내·외 자원을 연계한 프로젝트를 기획해 운영하도록 지원함

- 주민사업체 발굴과 사업 계획 수립 지원

- 관광두레PD가 전문가와 함께 지역관광 현안을 진단하고, 이를 기초로 주민사 업체를 발굴하며, 경쟁력 있는 관광사업 아이템을 도출할 수 있도록 지원함

- 관광두레PD가 사업 기간 중 지속적으로 주민사업체를 발굴하고, 전문가와 함께 주민사업체의 특성에 맞는 사업 계획을 수립하도록 지원함

- 주민사업체 창업과 경영 개선 지원

- 주민사업체가 창업 및 경영 개선에 이르는 전 과정에 필요한 교육·멘토링· 파일럿 비용을 지원함

- 구체적으로 선진 사례 견학, 기술 습득에 필요한 교육 수료, 전문가로부터 특정 분야의 기술 습득이나 사업 모델 구체화, 브랜드 개발을 위한 멘토링,

5) 관광두레사업 총괄 전담기관 기준으로 추진하는 사업 내용을 기술함 
시범적으로 관광객을 대상으로 관광상품이나 서비스를 판매해 보기 위한 재료비, 파일럿 운영 비용 등을 지원함

- 연계 통합 프로그램 운영

- 전국 단위로 관광두레사업에 참여하는 주민사업체 간 연계·협력을 유도하 고, 주민사업체 간 연계를 통해 상품 경쟁력을 강화하고자 연계 통합 프로 그램을 운영함

- 전국대회, 크라우드펀딩, 청년캠프, 사업아이템별 협업 프로그램 등이 그 예임

- 홍보·마케팅

- 홍보·마케팅 일환으로 관광두레 공식 웹사이트 운영, 페이스북 페이지 및 온라인 미디어 운영, 월간 뉴스레터 발간, 여행주간 운영, 청년서포터즈 운 영, 로컬투어마스터 운영, 각종 박람회 참가 등을 추진함

\section{5. 관광두레사업의 추진 현황}

- 문화체육관광부는 2013년 6월 관광두레 정책 기본계획을 수립하였고, 2013 년 7월부터 관광두레사업을 시행함

\section{가. 관광두레사업 대상지역}

- 관광두레사업 신규 대상지역으로 2013년 5개, 2014년 20개, 2015년 11개, 2016년 8개, 2017년 7개, 2018년 10개, 2019년 12개, 2020년 14개 기초 지방자치단체를 선정함6)

6) 2013년 신규 선정 지자체(5개): 경기 양평군(3년 완료), 강원 양구군(2년 완료), 충북 제천시(5년 완료), 전북 부안군(2년 완료), 경북 청송군(3년 완료)

2014년 신규 선정 지자체(20개): 인천 중구(1년 완료), 대구 중구(1년 미만), 경기 가평군(5년 완료), 수원 시(2년 완료), 철원군(1년 완료), 강원 강릉시(3년 완료), 인제군(2년 완료), 충북 영동군(2년 미만), 충남 공주시(3년 미만), 전북 김제시(3년 완료), 남원시(2년 완료), 무주시(2년 완료), 전남 곡성군(5년 완료), 순천시(2년 미만), 신안군(2년 미만), 여수시(5년 완료), 경북 봉화군(3년 완료), 울진군(3년 완료), 경남 남해군(5년 완료), 합천군(3년 완료)

2015년 신규 선정 지자체(11개): 광주 동구(3년 완료), 경기 연천군(5년 완료), 이천시(3년 완료), 강원 동해시(3년 완료), 홍천군(5년 완료), 충남 홍성군(5년 완료), 전북 익산시(4년 미만), 전남 구례군(3년 완 료), 해남군(2년 미만), 경북 안동시(5년 완료), 경남 거창군(3년 완료) 
- 관광두레사업의 성과가 나타나기 시작하면서, 2018년부터 관광두레사업 대상지역 수를 확대하는 추세임

- 매년 말 평가를 통해 사업 계속 추진 지역과 당해 년 완료 지역이 결정됨. 신 규 대상지역으로 선정되면 기본 3년에 추가 2년 간 사업 지원이 가능하지만 연 단위로 지역별 사업 평가에 따라 계속 추진의 타당성이 낮으면 해당 지역의 사업이 종료됨

- 2019년 관광두레사업은 전국 46개 기초지방자치단체를 대상으로 추진하였으 며, 192개 주민사업체 1,200여 명의 지역주민이 참여함(표 2-3 참고)

〈표 2-2〉 관광두레사업 연도별 추진 실적

\begin{tabular}{c|c|c|c|c|c|c|c|c}
\hline 구분 & 2013년 & 2014년 & 2015년 & 2016년 & 2017년 & 2018년 & 2019년 & 합계 \\
\hline 사업비 & 시범 & 20억 & 30억 & 40억 & 40억 & 60 억 & 80억 & 270억 \\
\hline 신규 사업대상지역 & 5개 & 20개 & 11개 & 8개 & 7개 & 10개 & 12개 & 73개 \\
\hline 신규 주민사업체 발굴 & 36개 & 105개 & 59개 & 51개 & 48개 & 68 개 & 113개 & 480개 \\
\hline $\begin{array}{c}\text { 신규 관광두레PD } \\
\text { (청년PD포함) }\end{array}$ & 6명 & 26명 & 14명 & 11명 & 7명 & 18명 & 20명 & 102명 \\
\hline
\end{tabular}

주: 관광두레PD는 2016년까지 팀(2인)으로도 선발하다 2017년부터 1인 선발로 변경되었으며, 2018년부터 청년관광두 레PD를 선발함

2016년 신규 선정 지자체(8개): 부산 동구(3년 완료), 경기 시흥시(2020년 5년차), 여주시(2년 미만), 강원 춘천시(2020년 5년차), 충남 천안시(1년 완료), 전북 군산시(3년 완료), 전남 나주시(2020년 5년차), 담양 군(4년 완료)

2017년 신규 선정 지자체(7개): 인천 강화군(2020년4년차), 강원 양양군(2020년4년차), 충남 아산시(2년 미만), 전북 장수군(2020년4년차), 전남 강진군(2020년4년차), 경북 상주시(3년 완료), 경남 통영시(3년 완료)

2018년 신규 선정 지자체(10개_정읍시 제외한 9개 지자체는 2020년3년차): 대구 동구, 경기 고양시, 강 원 삼척시, 속초시, 원주시, 충남 서산시, 예산군, 전북 정읍시(2년 미만), 전남 보성군, 경북 문경시 2019년 신규 선정 지자체(12개_영주시 제외한 11개 지자체는 2020년2년차): 대전 대덕구, 경기 안산시, 안성시, 파주시, 강원 정선군, 충북 괴산군, 충남 태안군, 전북 순창군, 전남 광양시, 경북 경주시, 영주시(1 년미만), 경남 산청군

2020년 신규 선정 지자체(14개_2020년1년차): 대전 동구, 세종시, 경기 용인시, 포천시, 강원 평창군, 충남 부여군, 청양군, 전북 진안군, 전남 고흥군, 순천시, 경북 영주시, 경남 거제시, 김해시, 진주시 각 관광두레사업 대상지역 별로 괄호 안의 기간은 $\mathrm{PD}$ 가 활동한 기간을 의미함. $\mathrm{PD}$ 가 개인적 사정에 의해 활동이 어려울 경우, 추가로 $\mathrm{PD}$ 를 재선정하거나 총괄지원기관에서 해당 지역의 주민사업체를 직접 관리함 
〈표 2-3〉2019년 관광두레사업 대상지 현황(2020년4월 말 기준)

\begin{tabular}{|c|c|}
\hline 구분 & 내용 \\
\hline 1차년 사업대상지(2019년 선정) & $\begin{array}{l}\text { - 대전 대덕구, 경기 안산시, 안성시, 파주시, 강원 정선군, } \\
\text { 충북 괴산군, 충남 태안군, 전북 순창군, 전남 광양시, } \\
\text { 경북 경주시, 경남 산청군 등 } 11 \text { 개 지역 }\end{array}$ \\
\hline 2차년 사업대상지(2018년 선정) & $\begin{array}{l}\text { - 대구 동구, 경기 고양시, 강원 삼척시, 속초시, 원주시, } \\
\text { 충남 서산시, 예산시, 전남 보성, 경북 문경시 등 9개 지역 }\end{array}$ \\
\hline 3차년 사업대상지(2017년 선정) & $\begin{array}{l}\text { - 인천 강화군, 강원 양양군, 전북 장수군, 전남 강진군, } \\
\text { 경북 상주시, 경남 통영시 등 } 6 \text { 개 지역 }\end{array}$ \\
\hline 4차년 사업대상지(2016년 선정) & - 경기 시흥시, 강원 춘천시, 전남 나주시, 담양군 등 4 개 지역 \\
\hline 5차년 사업대상지(2015년 선정) & - 경기 연천군, 강원 홍천군, 충남 홍성군, 경북 안동시 등 4 개 지역 \\
\hline $\begin{array}{l}\text { 한국문화관광연구원에서 직접 } \\
\text { 또는 지속관리 중인 지역 } \\
\text { (관광두레PD 지원 종료, 광역관광두레 } \\
\text { 센터 지원) }\end{array}$ & $\begin{array}{l}\text { - 광주 동구, 충남 아산시, 전북 군산시, 전남 구례군, 곡성군, } \\
\text { 순천시, 여수시, 경북 울진군, 봉화군, 청송군, 경남 거창군, } \\
\text { 남해군 등 } 12 \text { 개 지역 }\end{array}$ \\
\hline
\end{tabular}

주: 2019년 관광두레사업 대상지로서, 2019년 관광두레사업의 육성 및 지원 대상을 의미함

\section{나. 사업 내용 및 추진 체계 상 주요 변화}

- 매년 문화체육관광부와 총괄지원기관이 수립한 계획에 따른 "관광두레사업지 침”을 근거로 사업이 이루어짐

- 큰 틀의 사업 내용은 앞 서 제시한 대로 관광두레PD 선발과 역량 강화, 주민 사업체 발굴과 사업 계획 수립 지원, 주민사업체 창업과 경영 개선 지원, 연계 통합 프로그램 운영, 홍보·마케팅으로 구분되며, 사업의 세부 내용과 방식은 이해관계자 피드백을 통해 매년 개선해 나감

- 2019년에는 보다 세분화되고 고도화된 분과별 네트워킹 프로그램을 기획 해 주민사업체의 창업 의지를 높이고, 주민사업체 간 상호 협력과 교류를 강화하는 한편 맞춤형 성장촉진 지원과 엑셀러레이팅 지원을 통해 사업 모 델 고도화를 촉진함(문화체육관광부, 2020)

- 2018년 이후, 관광두레사업 추진 체계에 있어서 주요 변화는 청년PD의 선발 과 광역관광두레협력센터의 신설임

- 2018년은 관광두레사업이 시작된 지 6년차 되는 해임. 2013년 선정한 관 광두레사업 대상지역에 대한 5년간의 지원이 2017년에 완료함 
- 2018년부터 청년PD를 선정하여, PD와 청년PD 2인이 협력하여 활동할 수 있는 체계를 마련함

- 2013년부터 2016년까지는 관광두레PD를 각 기초지방자치단체 당 1인 혹 은 1팀(2인)으로 선발하였고, 2017년부터는 1인의 PD를 선발함

- 청년PD는 만34세 이하이고, 해당 기초지자체에서 활동할 수 있으며 PD 활동 지원 역량을 가진 자를 선발함

- 청년PD는 기존 $\mathrm{PD}$ 의 활동에 시너지 효과를 낼 수 있도록 지역 특성에 맞 게 역할을 분담해 활동함

- 2019년부터 관광두레 지역협력사업의 일환으로 광역관광두레협력센터를 구 성·운영하여 중앙정부와 지방정부 간 관광두레 협력체계를 마련함

- 관광두레 지역협력사업은 첫째, 중앙정부와 광역·기초지자체 협력체계 정 비를 통해 현장과 밀착된 관광두레 주민사업체의 확대 발굴 및 지속 성장 유도, 둘째, 지역과 주민 주도의 관광사업체 활성화를 통해 지역 일자리 창 출 및 지속가능한 지역관광 발전 생태계 조성을 목적으로 함

- 요컨대 문화체육관광부의 관광두레사업 대상지역으로 선정되기 전에 지역 주민들에게 주민 주도의 관광 사업에 대한 인식을 제고하고, 지역 인재를 양성하여 향후 관광두레사업 시행 시 주민사업체의 발굴과 성장에 기여하 고자 함. 더불어 최대5년 동안 주민사업체를 육성한 뒤 사후 관리 체계가 부족함에 따라 지역에 지속가능한 관광 발전 체계를 마련하기 위함임

- 예산은 광역시·도별 국비 연 2.5억 원에 지방비 $50 \%$ 를 매칭(국비: 지방비 $=2.5$ 억 : 2.5 억)하는 구조로서, 광역시·도가 광역관광두레협력센터를 구성 해 운영하도록 함

- 2019년에 공모를 통해 전남도, 경북도, 경남도가 선정됨. 전남도는 전남문 화관광재단(현 전남관광재단), 경북도는 경북문화관광공사, 경남도는 경남 관광협회에 사업을 위탁해 광역관광두레협력센터를 구성·운영함 


\section{2. 관광두레사업의 성과}

\section{1. 주민주도의 관광사업 모델 개발}

\section{가. 주민공동체를 관광사업체로 육성}

- 관광두레사업에서 지향하는 주민은 스스로 힘을 모아 해보자는 자발성과 협력 성을 가진 주민임. 지역관광 혹은 지역의 문제를 스스로 해결하려는 지역공동 체를 2019년까지 480개 발굴함

- 관광두레사업을 통해 발굴한 주민공동체 가운데 일부는 사업화 계획 수립 단계에서 공동의 지향점이 달라 와해되고, 또 일부는 창업 준비 단계에서 적정 수준의 자본을 모으지 못해 와해되기도 함. 그럼에도 불구하고 지역관 광에 대해 함께 생각해 볼 기회를 제공했다는 측면에서 의미가 있음

- 2019년까지 관광두레사업 지원을 토대로 창업 및 경영 개선을 완료한 주민사 업체는 110 개임. 전국 지역 곳곳에 주민들이 직접 만들고 경영하는 다양한 지 역관광 주민사업체를 창출했다는 데 의의가 있음

- 누구보다 지역에 대해 잘 알고 있는 주민들이 서툴지만 진심이 담긴 관광상 품과 서비스를 제공하기 때문에, 관광객들은 새로운 경험과 만족을 느낌

\section{나. 주요 사례}

1) 식음

- (여수, 수레인보우협동조합) 여수의 다문화여성들에게 안정적인 일자리를 제 공해 주는 데 뜻을 같이 한 여수시민들이 협동조합을 결성해 '여수1923'이라 는 한상차림 여행자식당을 창업함. 여수 관광객 중 1 인 관광객의 비중이 높음 에도 1 인분 메뉴를 제공하는 식당이 별로 없다는 점에 착안해, 여수 로컬푸드 를 활용한 한상차림 메뉴를 개발함

- (춘천, 유한회사법인 더티파머스) 건강한 먹거리에 관심이 많던 세 명의 청년 이 의기투합해, 직접 지은 농산물로 건강한 음식을 만들어 소비자들에게 전달 하고자 식당을 창업함. 관광두레사업 지원을 통해 춘천의 지역적 특성을 메뉴 
로 담아내고, 식재료로 로컬푸드를 활용함으로써 춘천 먹거리 여행이 지역경 제 활성화에 영향을 미치게 함

\section{2) 숙박}

- (안동, 서로가협동조합) 안동 전통고택 안주인들이 각 집안에 전해 내려오는 전통문화와 음식 등을 전하고, 고택에서의 숙박 경험을 공유하고자 협동조합 을 구성함. 고택 숙박과 헛제사밥, 전통술 등 체험상품을 운영함

- (춘천, 쟁강협동조합) 춘천 서면에서 게스트하우스 등 숙박업을 하고 있는 다 섯 명의 사업자들이 지역사회 발전에 기여하며 공동의 수익모델을 구축하기 위해 협동조합을 구성함. 춘천의 아름다운 환경을 잘 알리고자 자전거 코스를 짜고, 코스 내 각 포인트에서 미션을 수행하는 프로그램 등을 공동 운영함

\section{3) 주민여행사}

- (시흥, 협동조합공정여행동네) 시흥을 자녀들에게 자랑스러운 고향으로 만들 어주고 싶은 마음을 가진 전업주부들이 모여 여행사를 창업함. 시흥의 문화와 자연 자원을 엮은 체험여행상품을 판매하며, 기업, 가족, 단체 등 모임 성격에 맞춘 다양한 상품을 운영함

- (홍성, 주식회사 행복한여행나눔) 홍성에 위치한 대학교에서 관광을 전공한 학 생들이 모여 게스트하우스와 여행사를 창업함. 대학에 다니며 알게 된 홍성의 매력을 제대로 알리고 싶다는 마음에서, 100년 넘은 한옥이자 7년 넘게 비어 있던 집을 손수 개조해 게스트하우스를 오픈함. 젊은 감각으로 홍성의 구석구 석에 숨겨져 있는 자원들을 연계한 여행상품을 판매·운영함

\section{4) 기념품}

- (곡성, 수상한영농조합법인) 곡성을 대표하는 먹거리 관광 상품을 만들고 싶은 의지를 가진 주민들이 모임. 곡성이 전국 토란 생산량의 $70 \%$ 를 차지하는 데 착안하여 토란을 활용한 어묵, 푸딩 등 다양한 먹거리 개발을 시도하고, 결국 
곡성과 토란의 특성을 모두 담은 '토란파이만주'를 개발함. 곡성 여행 중 간식 으로, 곡성 여행을 기념하는 기념품으로 탄생함

- (담양, 담양대나무공예인협동조합) 저가의 중국산 대나무 공예품이 기념품 매 장을 가득 채우는 현실에 위기의식을 느낀 대나무 공예 계승자와 공예가들이 협동조합을 결성함. 대나무 공예품을 더욱 가치 있고 쓸모 있게 만들어, 대나 무 공예품의 전성기를 되찾고 담양을 대표하는 기념품을 만들고자 함

5) 체험

- (양평, 양평수상안전교육원) 양평중·고등학교 카누부 선수 출신 주민들이 모 여 ‘동동카누'라는 레저체험업체를 창업함. 카누부 후배들에게 양평에서 특기 를 살려 일할 수 있는 일자리를 만들어주고, 양평을 찾는 관광객들에게는 새로 운 체험거리를 제공하고자 함

\section{2. 지역경제 활성화 효과 도출}

- 2019년까지 관광두레 주민사업체의 매출액(누적)은 426억4천만 원임. 2019 년까지 관광두레사업에 투입한 사업비 총액 270억 원과 비교하면, 약 1.6배에 달하는 수치임

- 단순하게 관광두레사업에 투입한 사업비와 관광두레사업으로 육성한 주민 사업체가 창출한 매출액만 비교한 수치이긴 하나 비용 대비 효과가 있다고 볼 수 있음

〈표 2-4〉 주민사업체 누적 매출액

(단위: 백만 원)

\begin{tabular}{c|c|c|c|c|c}
\hline 구분 & 2015년 & 2016년 & 2017년 & 2018년 & 2019년 \\
\hline 누적 매출액 & 4,642 & 10,284 & 21,347 & 34,300 & 42,640 \\
\hline
\end{tabular}

- 2019년 주민사업체의 연간 매출액은 83억4천만 원이며, 850 명의 일자리를 창출하는 등 지역경제 활성화 효과를 도출함(문화체육관광부, 2020) 
- 고정적인 매출이 집계되는 주민사업체는 2019년 65개였으며, 2019년3월 부터 12 월까지 월 평균 1,018 만 원의 매출이 발생하였고, 월 평균 6.7 명을 고용함

- 강원 춘천 쟁강협동조합은 자전거 타고 빙고 투어, 게스트하우스, 쟁강에서 면 굿즈 기념품 등을 판매해 월 평균 3,118 만 원의 매출과 4.5 명의 고용 인원을 나타냄

- 경기 시흥 협동조합공정여행동네는 지역의 자원을 활용한 맘 따라 여행, 생 태예술여행 등 상품을 지속적으로 개발해 월 평균 2,269만 원의 매출과 25.5 명의 고용 인원을 창출함

- 더욱이 관광두레 주민사업체는 지역자원을 활용하여 관광상품과 서비스를 만 들어 지역 내 관광소비가 순환되도록 지향하는 점을 고려하면, 주민사업체의 상품과 서비스에 대한 전후방 경제적 파급 효과는 더욱 큼

\section{3. 지역관광 주체 육성}

\section{가. 관광두레PD 선발(지역관광 기획자 양성)}

- 관광두레 $\mathrm{PD}$ 는 지역주민 가운데에서 선발하고, $\mathrm{PD}$ 로서 역할을 수행할 수 있 도록 교육·워크숍 등을 통해 역량을 강화시킴. 기존 다른 정책 사업에서 외부 에 있는 전문가를 지역과 매칭하여 지역을 지원하는 방식과 다름

- 2013년부터 2019년까지 102명의 관광두레PD가 선발되어, $\mathrm{PD}$ 활동기간 동 안 다양한 역량 강화 교육과 전문가 멘토링을 받음

- 지역의 이해, 지역 관광자원 조사 및 개발, 사업계획서 작성, 커뮤니케이션 스킬, 법인 설립, 사업성 평가 등 $\mathrm{PD}$ 로서 역할을 수행하는 데 필요한 역량 을 강화함(박주영, 2020)

- 관광두레사업이 종료된 이후, 관광두레 $\mathrm{PD}$ 는 지역관광 관련 중간지원조직에서 활동하거나 주민사업체의 일원으로 지역관광을 활성화하는데 주도적인 역할 을 수행하고 있음 
- $\mathrm{PD}$ 활동 종료 후에도 지역 내에서 다양한 활동을 지속함으로써 지역 발전에 기여할 수 있는 기반을 마련함

\section{나. 지역주민을 관광 주체로 육성}

- 2013년부터 2019년까지 매년 1,200여 명의 주민이 관광두레사업에 참여함. 관광두레사업에 참여하는 주민들은 지역관광 혹은 지역의 문제를 관광사업으 로 해결하고자 창업 또는 경영개선에 필요한 역량을 쌍음

- 창업과 경영개선을 완료한 주민사업체는 관광사업자로서 지역관광 상품과 서 비스를 생산·판매하는 실질적 주체가 됨. 지역 전문가들은 비록 창업과 경영 개선을 완료하지 못한 주민들의 경우도 관광두레사업에 참여함으로써 지역관 광의 문제를 고민하고, 문제를 해결하기 위한 역량을 강화했기 때문에 잠재적 관광 주체가 되었다고 평가함

- 특히 앞서 주민여행사 사례로 소개한 (주행복한여행나눔은 문화체육관광부가 2020년부터 본격적으로 추진하는 '지역관광추진조직(DMO: Destination Management/Marketing Organization)' 육성지원 공모사업에 선정되어 홍성군 관광 관련 기업과 협회, 주민조직과 협력 연계망을 구축하고 관광 콘텐츠를 기획해 지역의 관광을 발전시키는 주춧돌로 한 단계 더 발전함 (박주영, 2020)

\section{4. 지역주민의 인식 변화}

- 관광두레사업을 통해 단계별로 맞춤형 지원을 받아 주민사업체를 창업한 주민 들은 ‘우리도 할 수 있다'는 자신감을 얻었을 뿐 아니라 ‘공동체', ‘협력'이라는 가치가 더해지면 더욱 경쟁력을 갖춘 관광상품을 만들어 낼 수 있음을 인지하 게 됨(박주영, 2020)

- 기존에는 공급자 중심으로 상품과 서비스를 개발하였다면, 관광두레사업의 육성 과정을 통해 고객이 필요로 하는 것을 상품과 서비스로 만들어야 한다 는 것을 인식하게 됨 
- 이 같은 인식 변화는 매년 실시하는 주민 대상 설문조사 결과에서 살펴볼 수 있음. 2018년과 2019년 하반기에 실시한 설문조사 결과에 따르면, 관광두레 사업을 통해 '공동체 의식 향상(전년 대비 5.2\%p 증가)', '자발성과 주민의식 향상(전년 대비 $4.9 \% \mathrm{p}$ 증가)', '지역관광 활성화(전년 대비 $4.3 \% \mathrm{p}$ 증가)', '공 동의 목표 달성을 위한 협력 강화(전년 대비 $4.0 \% \mathrm{p}$ 증가)', '지역 경제 순환 (전년 대비 $2.8 \%$ p 증가)' 등 모든 항목에서 긍정적 변화를 나타냄. 더욱이 관 광두레사업으로 인한 긍정적 변화에 대한 인식이 80점 이상으로 높게 나타남

[그림 2-2] 관광두레사업을 통한 주민들의 인식 변화

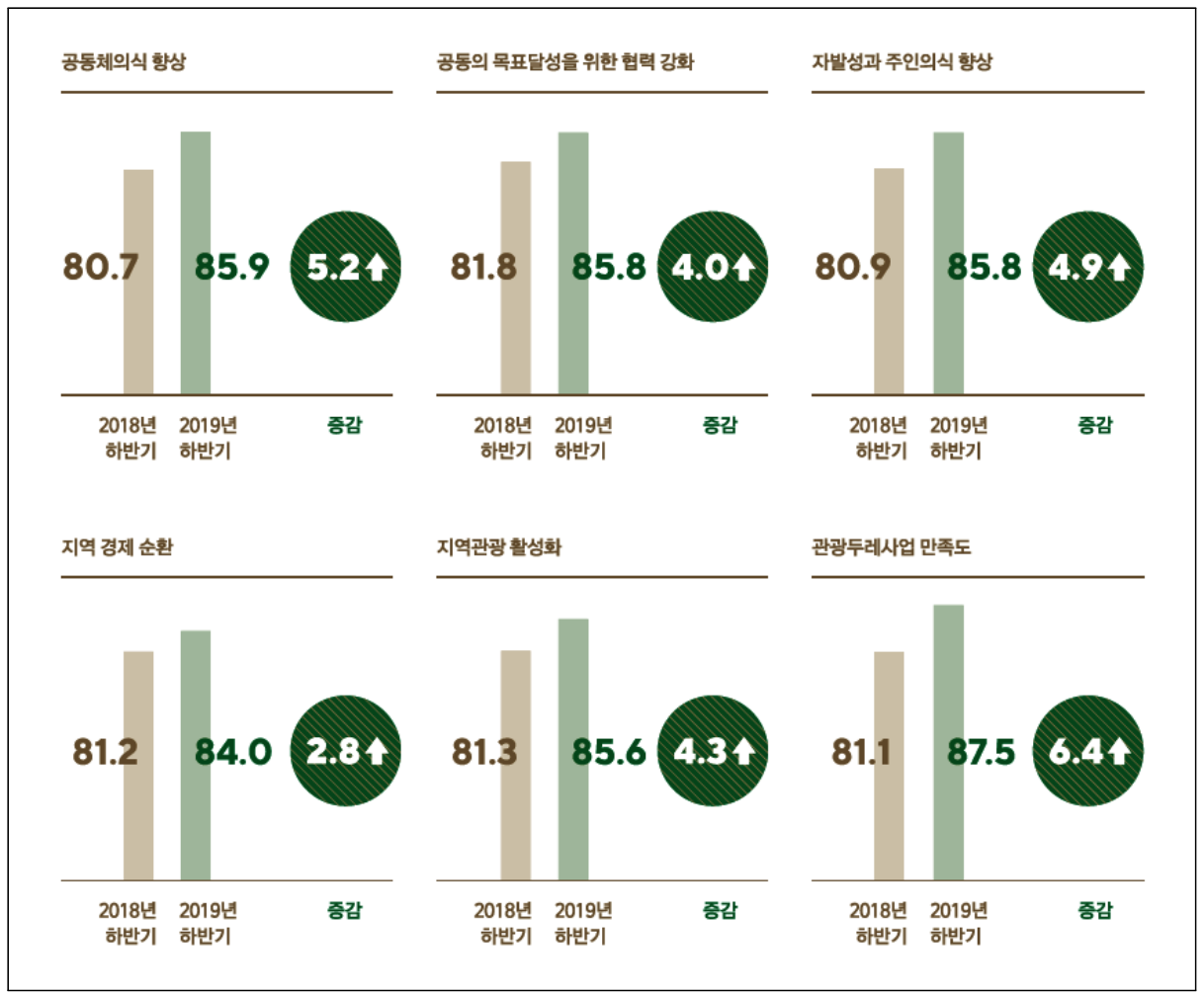

주: 2018년과 2019년 11월, 전국의 관광두레 주민사업체 전수를 대상으로 사업체 당 2명의 주민이 관광두레사업을 통한 변화에 대해 응답한 결과임

자료: 문화체육관광부·한국문화관광연구원(2020) 
- 또한 주민들이 자발적인 역량 강화 노력을 기울이고, 상품 개선을 위해 노력하 는 등의 변화를 보임. 관광두레 주민사업체로서 지역에 기여하려는 움직임도 나타냄

- 주민들이 역량을 강화하고자 교육이나 아카데미 과정을 이수하거나, 지역축 제나 박람회 등에 참여하여 관광객들에게 상품과 서비스를 판매하고 개선 점을 찾는 등 자발적인 활동을 보임

- 수익의 일부를 지역 단체에 기부하거나, 개발한 상품을 지역의 어려운 이웃 에게 나누는 등의 지역사회공헌 활동도 나타남

\section{5. 정책 패러다임 변화 선도}

- 관광두레사업의 시작을 계기로 관광산업의 공급자(사업체, 인프라) 및 소비자 (관광객) 중심의 관광정책에서 지역주민을 정책의 한 주체로 인식하는 지속가 능한 관광정책으로 전환됨(문화체육관광부, 2020)

- 기존에 지역주민을 관광 소비자, 피고용인, 방관자로 인식했다면, 이제는 지역관광의 생산자이자 소비자로서 인식함

- 관 주도형 하드웨어 중심의 지원방식보다 인재 육성과 주민 주도 역량 강화 등 소프트웨어 중심의 지원이 지역 발전에 있어 더욱 긍정적 효과를 나타낸다 는 것을 관광두레사업이 증명해 낸 덕분에 농림축산식품부와 환경부, 산림청 등 타 부처에서도 해당 영역에서 활동할 지역주민 등 인적 자원 중심의 지원 사업을 다수 추진함(박주영, 2020)

- 관광두레 $\mathrm{PD}$ 를 통한 지역 현장 중심의 지원 방식이나, 관광두레 주민사업체 간의 협력을 통한 경쟁력 강화 방식 등이 타 부처 및 기관의 사업에 활용됨 - (제주관광공사, 제주 삼촌PD) 관광두레 $\mathrm{PD}$ 를 참고하여 2017년부터 제주마 을여행활동가 육성

- (산림청, 산림일자리발전소) 관광두레사업을 벤치마킹하여 산림자원을 활용 한 공동체사업 지원체계를 마련함. 2018년 산림일자리발전소 설립 및 그루 매니저 육성 시작 
- (환경부, 생태관광디렉터) 생태관광 지역 주민 및 종사자들의 전문성 향상 과 취업 및 창업지원을 돕는 '생태관광 디렉터 양성 과정' 등 프로그램 운영

- (농림부, 주민주도 농촌관광 콘텐츠 개발) 관광두레사업의 지원 체계와 주민 사업체의 사업 모델을 참고하여 2018년부터 주민주도형 농촌관광 콘텐츠 개발 사업을 추진함. 농촌관광 운영주체와 지자체, 전문가, 현장활동가 등이 농촌관광 협의체를 구성해 농촌관광 콘텐츠를 개발·운영할 수 있도록 지원 


\section{제2절 관광두레사업의 한계}

- 본 절에서 다루는 관광두레사업의 한계는 법·제도적 근거 부재에 따른 내용으 로 한정함

- 관광두레사업 추진 과정에서 법·제도적 근거 부재로 인해 나타나는 한계점을 도출하고자, 이해관계자 심층조사를 시행함. 본 절의 내용은 심층조사 결과에 기초함

\section{1. 심층조사 개요}

- 목적: 관광두레 근거 법 부재에 따른 애로사항, 법제화 필요성 등 의견 수렴

- 대상: 관광두레 이해관계자 20명

- 관광두레PD 및 청년PD 11명, 광역관광두레협력지원센터 3명, 주민사업체 2명, 지자체 담당자 4명

- 조사 방법: 구조화된 설문지 응답 및 인터뷰

- 조사 내용

- 관광두레사업에 대한 법적 근거 부재로 인한 어려움 경험 여부

- 법적 근거 부재로 겪은 어려움 경험 사례

- 관광두레 법제화 필요성에 대한 공감대

- 법제화 필요성

- 법령 마련 시, 포함하여야 하는 내용

- 관광두레 법제화 관련한 기타 추가 의견 


\section{2. 추진 과정상 한계점}

\section{1. (1차년) 관광두레PD 선발}

\section{가. 관광두레 $\mathrm{PD}$ 의 역할, 관광두레사업에 대한 이해 부족}

- 관광두레 $\mathrm{PD}$ 로 선정 시에는 지방자치단체에서 활동 지원 등을 약속하였으나, 담당공무원이 계속 바뀌면서 약속이 이행되지 않음

- 관광두레사업이 지역주민 주도의 관광생태계를 만들어 내 지역관광 활성화와 일자리 창출 등에 기여하는 사업임에도 불구하고, 법적 근거가 부족하다보니 지방자치단체에서는 사업 추진 지원에 대한 관심도가 낮음

- "지방자치단체의 예산 매칭 없이 사업 체계를 구상한 의도가 있겠지만, 지 방자치단체와 함께 하고 최종적으로는 지역 내에 스스로 자생하는 주민사 업체 육성을 목표로 한다면 사업 초기부터 지방자치단체와 협력할 수 있는 방안을 마련해야 합니다.”(지방자치단체 담당자)

- 지역 내·외 기관과 네트워크 구축 시, 관광두레 $\mathrm{PD}$ 를 중간지원주체로 인정해 주 지 않음. 아울러 중간지원주체로서 업무 범위나 권한 등에 대해 보장받지 못함 - "관광두레사업은 지역 내·외 여러 기관이나 단체 등과의 네트워크가 중요함 에도 불구하고, 관광두레 $\mathrm{PD}$ 를 지역중간지원주체로 인식하지 않는 경우가 많습니다. 그리고 $\mathrm{PD}$ 의 업무 권한이나 범위 등에 대한 기본적인 권리를 보 장받지 못 하는 상황입니다." (관광두레PD)

\section{나. 관광두레사랑방 지원 어려움}

- 관광두레사랑방은 $\mathrm{PD}$ 의 근무공간이자 주민사업체들의 회의 및 교육 공간, 관 광두레사업의 소통 창구 등의 역할을 하여 관광두레사업의 원활한 추진을 위 한 핵심적인 기반시설로 볼 수 있음

- 관광두레사업의 신규 대상지역과 $\mathrm{PD}$ 를 공모하는 과정에서 지방자치단체의 경우 '관광두레사업 협력계획서'를 제출하고, 관광두레사랑방 공간 마련에 대 한 협력 지원 계획을 기재함 
- 하지만 관광두레사업 대상지역으로 선발된 이후, 지방자치단체 담당자들은 법 적 근거 부족으로 관광두레 사랑방 공간을 마련하고 사무 집기를 지원하는 데 에 어려움을 토로함

- "사실 공무원은 순환 보직이기 때문에 협력계획서 제출 시의 담당자와 상급 자가 신규 대상지역으로 선발된 이후에는 변경될 수도 있고요. 협력계획서 의 제출 자료만으로 공간을 마련하고 운영 경비까지 지원하는 데 어려움이 있는 게 사실입니다."(지방자치단체 담당자)

- "지방자치단체 추천으로 관광두레사업 공모에 참여하였고 관광두레사랑방 을 지원하기로 하였지만, 실질적인 지원까지는 다소 시간이 걸려서 어려움 이 있었습니다. 조례나 지원 근거가 미흡하다는 이유로 명확하게 확정하지 않아 혼란이 있었습니다."(관광두레PD)

\section{2. (1 3차년) 주민사업체 육성}

\section{가. 지방자치단체의 적극적 협력 유도 어려움}

- 관광두레사업에 대한 지방자치단체의 역할이 법적으로 명시되어 있지 않고 지 방자치단체가 예산을 매칭하지 않다 보니, 사업에 대한 관심도가 높지 않음. 지방자치단체의 협력을 원활하게 이끄는 일은 관광두레 $\mathrm{PD}$ 의 개인 역량의 문 제로 맡겨짐

- "1차년에는 주민사업체 발굴을 위한 행정 지원을 했으나, 그 이후에는 지방 자치단체에서 관광두레사업에 대한 별도의 예산 편성이 없다보니 업무의 우선 순위에서 밀려날 수밖에 없습니다.”(지방자치단체 담당자)

- "법적 근거도 없고, 기본적으로 국비로 진행되는 사업이다 보니 지방자치단 체 담당자는 관광두레사업을 본인 업무로 인식하지 않는 경우가 많습니다. 그런데 관광두레사업 추진을 위해 지방자치단체의 지원 등을 받아야 할 경 우, 담당자 입장에서는 갑자기 일거리가 생기는 상황으로 인식돼 관광두레 $\mathrm{PD}$ 와 지방자치단체 담당자 간 불편한 관계가 되기도 합니다.”(관광두레 $\mathrm{PD})$

- 관광두레PD가 관광두레사업의 원활한 수행을 위해 지방자치단체의 지원을 
받고자 담당자와 협의 시, 법적 근거가 없어 어렵다는 답변을 듣는 사례가 많 음. 지방자치단체에서 관광두레사업에 대한 취지에 공감하고 융통성을 발휘해 지원을 해 주는 경우도 있지만, 지원 결산 보고서에는 명시적으로 관광두레사 업 지원으로 기재하기 어려워 지속적인 지원체계 마련이 어려움

- "담당자에 따라 관광두레사업에 대한 지원 방향이나 의견이 달라 애로가 많 았습니다. 지방자치단체의 역할에 대한 명확한 지침이나 근거 법이 없기 때 문이라고 생각했습니다.”(관광두레PD)

\section{나. 주민사업체에 대한 지원 근거 미비}

- 관광두레 주민사업체는 창업 이전에는 공동체 조직이기 때문에 지방자치단체 에서 지원할 근거가 없음

- "관광두레 주민사업체는 공동체 단계부터 육성해야 하는데 지방자치단체장이 공동체 활성화에 대한 관심이 있지 않다면, 아무런 법적 근거가 없어 지방자 치단체의 지원을 받기가 어렵습니다. 오롯이 지역사회 공동체에서 관광두레 $\mathrm{PD}$ 와 주민들이 관광두레사업을 진행해야 하는 상황이 됩니다.”(관광두레 $\mathrm{PD}$ )

- 지방자치단체 담당자 입장에서는 다른 조직도 있는 데 왜 관광두레 주민사업 체를 지원해야 하는 지에 대한 명분이 부족하고, 예산을 마련해야 할 경우 의 회를 설득할 만한 근거가 없어 어려움을 겪음

- "사회적기업, 마을기업, 6차산업기업 등은 지원에 대한 내용이 비교적 명확 하고, 지원 받기가 수월합니다. 하지만 관광두레 주민사업체는 관련 근거가 없어서 어려움이 많습니다.”(지방자치단체 공무원, 관광두레 PD)

- 관광두레 주민사업체는 지역 내 국립공원, 관광특구, 문화재 등 관광지를 연 계·활용하는 경우가 많음. 이러한 장소를 연계하거나 활용하려면 담당 부서의 승인을 얻어야 하는데, 이용할 때마다 승인을 받아야 해서 시간 행정적 소모 가 큼. 때로는 공공 관광지라 수익 사업을 할 수 없다는 제재를 받기도 함 - "관광두레 주민사업체는 지역관광 활성화, 지역경제 순환 등 공공성을 목표 로 사업을 수행함에도 불구하고, 수익만 추구하는 관광사업자로 취급하는 
경우가 있습니다. 관광두레사업으로 육성한 주민사업체이자 주민 주도 관 광이라는 의미를 무색하게 만들기도 합니다.”(관광두레PD)

- 관광두레사업은 소프트웨어 지원을 중심으로 하다 보니, 주민사업체의 창업 공간을 마련하는 데 어려움이 있음. 지방자치단체의 유휴공간을 활용하면, 지 역 발전과 주민사업체 창업 양측에서 시너지 효과를 낼 수 있을 것으로 생각되 나, 지방자치단체의 유휴공간을 관광두레 주민사업체에게 지원할 수 있는 법 적 근거가 없음

- "관광두레 주민사업체가 지역 내 폐교를 숙박시설로 운영해 볼 기회가 있었 지만, 관광두레 주민사업체에 대한 법적 근거가 없어서 결국 성사되지 못 했습니다."(관광두레PD)

\section{3. (4 5차년) 재정 지원 및 사후 관리}

\section{가. 추가 2 년 지원 대상지역의 경우 5 차년 예산 매칭 근거 미흡}

- 관광두레사업 기간은 기본 3 년, 그리고 종합평가를 거쳐 추가 2 년을 지원하는 구조임. 종합평가 시, 기초지방자치단체가 5차년에 예산을 매칭하고, 지역의 관광두레 협력 모델을 구축하는 데 얼마나 지원할 것인지에 대한 계획과 의지 를 평가하지만, 실제로 5 차년에 지방자치단체가 예산을 마련하는 데 대한 법 적 근거가 없어 어려움을 겪음

- “종합평가를 통해 추가 2년 대상지역으로 선정되어도 지방자치단체가 5차 년도 예산을 지원해야 한다는 것은 방침으로만 존재할 뿐 해당 지방자치단 체에서는 예산 마련에 대한 직접적인 근거가 없습니다."(관광두레PD)

\section{나. 중간지원조직의 원활한 운영 어려움}

- 광역시도에서 예산을 매칭하여 광역관광두레협력지원센터가 2019년부터 운 영되고 있지만, 중간지원조직에 대한 지원 근거가 마련되지 않아 협력사업의 지속성을 담보하기 어려운 상황임. 또한 현재는 지역의 재단, 공사, 협회 등에 서 사업을 위탁받아 내부적으로 광역관광두레협력센터를 구성해 광역관광두 
레협력사업을 추진하다보니 각 기관의 행정시스템과 관광두레협력사업의 지 원 방식 등이 불일치하여 사업 추진에 어려움이 있음

- "관광두레사업의 강점이 유연성과 현장 밀착, 주민 주도 등인데 재단, 공사, 협 회 등의 행정 시스템에 맞춰 사업을 추진하다보니 소기의 목적 달성에 어려움 이 있습니다. 특히 현재 광역관광두레협력센터에는 결재권한이 없어, 의도한 사업 내용대로 추진하지 못 하는 경우도 있습니다.”(광역관광두레협력센터)

- 중간지원조직에 대한 법적 근거에 있으면, 관광두레사업 성격에 부합한 조직 을 구성하여 중간지원 역할을 수행할 수 있으나 현재로서는 한계가 있음

- “광역관광두레협력센터가 독립적 사업 주체가 되지 못 하다 보니, 위탁 기 관의 시스템 및 지시에서 자유롭지 못합니다. 이는 고스란히 사업의 방향과 과정에 영향을 줄 수밖에 없습니다."(광역관광두레협력센터)

\section{다. 관광두레 주민사업체에 대한 지속적인 지원 및 관리 어려움}

- 기본 3년 및 최대 5년의 기간 동안 관광두레 주민사업체로서 지원을 받고, 이후에는 추가 지원 없이 자생력을 갖춰 경영하도록 하는 것이 관광두레사업 의 목표이지만, 해당 기간 이후에도 관광두레 주민사업체로서 지원 및 관리될 필요가 있음

- "3년 혹은 최대 5년 간의 지원 및 육성이 종료된 이후, 발굴·육성된 주민사 업체의 지속 관리가 필요합니다. 이를 위해 안정적인 중간지원기관이 필요 합니다.”(관광두레PD)

- 관광두레 주민사업체는 지역문제 해결, 지역경제 순환, 공동체 협력에 기초한 사업 구조 등 사회적 경제 조직의 설립 목적과 형태 등을 띠고 있음에도 불구 하고, 사회적 경제 조직으로 인정받지 못 함. 그로 인해 공공시설 활용, 공공기 관 우선구매제도 등 사회적 경제 조직의 여러 혜택을 받지 못 함

- "관광두레 주민사업체를 단순히 수익 창출을 목적으로 하는 민간사업자로 인식하는 경우가 많습니다. 사회적기업 등이 받는 혜택을 관광두레 주민사 업체는 받을 수 없어 지속적인 성장에 어려움이 많습니다.”(관광두레PD) 


\section{3. 법제화 필요성에 대한 인식}

\section{1. 이해관계자들의 공감대}

\section{가. 관광두레사업에 대한 직접적 근거 법령 부재에 따른 어려움 경험}

- 심층조사에 참여한 이해관계자 20 명 가운데 17 명이 관광두레사업을 수행 혹 은 참여하면서 법적 근거 부재로 인해 어려움을 겪은 경험이 있다고 응답함

- 어려움을 경험하지 않았다고 응답한 경우는 2 년 차 관광두레PD 1 명과 주 민사업체 2명임

- 2년 차 관광두레PD의 경우, 해당 지방자치단체가 관광두레사업에 대한 이 해도가 높고 관광두레사업의 필요성을 공감하고 있어 협력이 잘 되기 때문 에 현재까지 사업 추진 과정에서 근거 법령 부재로 인한 어려움은 없었던 걸로 이해됨

- 주민사업체의 경우, 관광두레사업 지원이 관광두레 PD를 통해 이루어지기 때 문에 법적 근거 부재에 따른 어려움을 직접적으로 겪지 않은 것으로 파악함

\section{나. 관광두레사업 법제화 필요성}

- 심층조사에 참여한 이해관계자 전원은 관광두레사업의 법제화 필요성에 대해 '매우 필요하다' 혹은 '필요하다' 고 응답함

- 관광두레사업의 법제화 필요성에 대한 공감 정도는 5점 만점에 4.8점을 기록함

1) 지방자치단체 지원의 근거, 지방자치단체의 적극적 참여와 지원 의지 고취

- 지방자치단체 담당자와 관광두레PD 모두, 관광두레사업에서 지방자치단체의 협력이 대단히 중요하다고 인식함. 또한 지방자치단체의 지원이 원활하게 이 루어지기 위해서는 법적 근거가 필요하다고 응답함

- "관광과장 및 팀장이 바뀔 때 마다 관광두레사업을 이해시키는 데 상당한 기간이 걸리는 경우도 있습니다. 과장님께서 사업 취지는 좋으나, 우리 부 서보다는 지역경제과나 농업정책과에서 하는 것이 낫다고 하시는 분도 계 셨습니다. 문화체육관광부 소관의 관련 법령이 있고, 법에 따라 지원 및 육 
성하는 사업이라고 하면 관광두레사업의 지원이 쉬웠을 것입니다.”

(지방자치단체 담당자)

- 법적 근거가 부재함에도 관광두레사업에 대한 지방자치단체 담당자의 이해도 와 관심도에 따라, 또는 관광두레 $\mathrm{PD}$ 의 적극적 활동 역량에 따라 큰 장애 없이 관광두레사업을 수행하기도 함. 하지만 정책 사업을 지역 간 편차 없이 실행하 기 위해서 법적 근거 마련이 필요함

- “지방자치단체 담당자가 바뀔 때 마다 관광두레PD가 사업의 특징을 설명하고 설득하는 과정에 너무 많은 에너지를 쏟게 됩니다. 담당자들이 짧게는 6 개월, 길게는 2 년 간격을 두고 교체되는 데, 이때마다 다시 관광두레사업을 설명하 고 지원을 위한 동의와 협조를 받기가 너무 힘이 듭니다."(관광두레 PD)

2) 지역 관광자원 활용, 연계의 보장

- 관광두레 주민사업체가 지역 내 관광지를 연계·활용해 관광 상품과 서비스를 제공함으로써 체험거리, 먹거리 등이 풍부해져 지역관광 매력도 및 관광객 만 족도가 향상됨에도 불구하고, 지역 관광자원을 활용할 경우 담당부서의 승인 을 매번 받아야 하는 어려움을 토로함. 관광두레사업이 지역자원을 연계·활용 하며, 주민사업체가 공공성을 띤 조직이라는 부분이 법적으로 명시되면, 지역 주민들이 지역 관광자원을 활용하고 연계하는 것이 원활할 것으로 판단함

- "관광두레사업에 대한 법적 근거가 있으면, 주민사업체에 대한 적극 행정을 펼칠 수 있습니다."(지방자치단체 담당자)

- 지역 내 유휴공간이나 공공시설을 관광두레 주민사업체가 운영할 수 있도록 법적 근거가 마련되면, 지역 관광시설의 운영·관리 측면에서도 긍정적 효과가 나타날 수 있음

3) 지역주민, 전문가 등 관광두레사업 참여 활성화 기반

- 주민사업체 대표는 관광두레사업의 직접적인 법적 근거가 마련될 경우, 사업 참여에 대한 애착심과 자긍심, 책임감 등이 더욱 제고될 것으로 응답함. 관광 두레PD도 주민뿐만 아니라 관광두레사업에 참여하는 관계자들의 자존감과 
자긍심이 높아질 것으로 응답함

- "관광두레사업이 단지 정책사업의 하나가 아니라 법적으로 근거가 있다면, 주민사업체 구성원들이 훨씬 사업 참여에 대한 애착심과 자긍심, 그리고 책 임감이 생길 것으로 생각합니다."(관광두레 주민사업체 대표)

- "관광두레사업을 수행하면서 현장에서 가장 필요하다고 느낀 것이 참여자 들의 열정과 의지입니다. 법적 근거가 있으면, 관광두레사업에 참여하는 전 문가, 주민 등 관계자들의 자존감과 자긍심이 높아질 수 있다고 생각합니 다."(관광두레PD)

- 주민사업체의 경우 법제화 시 주민사업체에 대한 다양한 지원이 가능할 것으 로 기대하고, 이를 토대로 법제화 필요성에 대해 공감함

- "법적 근거가 마련될 경우, 주민사업체에 대한 다양한 지원이 이루어질 수 있다고 생각합니다. 예를 들어, 관광진흥개발기금을 관광두레 주민사업체 에게 융자할 수 있도록 한다거나, 여행업 등록 시 자본금을 인하해 준다거 나 하는 등 혜택을 부여할 수 있을 것입니다."(관광두레 주민사업체 대표)

4) 주민사업체에 대한 효율적인 관리

- 관광두레사업이 확대됨에 따라 사업에 참여하는 주민사업체 수도 점차 증가 함. 또한 여러 유사한 지원 사업이 늘어나고 있음. 이에 대해 지방자치단체 담 당자는 지원 단계에서 지원금을 부정 수급하거나 관광사업 경영 단계에서 관 광두레사업의 취지에 맞지 않게 운영하는 사례 등이 발생하지 않도록 주민사 업체에 대한 관리가 필요하다고 응답함

- "좋은 취지의 관광두레사업이 지속되기 위해서는 주민사업체에 대한 관리도 필요합니다. 관광두레사업은 주민들에게 직접적인 사업비가 지원되지는 않 지만, 중복 지원되거나 관광두레사업 취지에 맞지 않는 주민사업체나 사업 내용에 예산이 소요되지 않도록 관리가 필요합니다.”(지방자치단체 담당자) 
5) 지속적인 관광두레사업 지향 가치 확산 및 지자체 조례 제정 근거

- 조사에 참여한 2차년 $\mathrm{PD}$ 의 경우 관광두레사업을 수행해 오면서 법적 근거 부재로 인해 어려움을 겪은 경험은 없었다고 응답하였으나, 관광두레사업이 지역사회 기반형 관광(community based tourism)의 시스템을 마련하는 사 업으로서 자리매김하기 위하여 법적 근거가 마련되어야 한다고 응답함

- 5차년 $\mathrm{PD}$ 의 경우, 관광두레사업 지원이 완료된 이후에도 관광두레사업이 지 향하는 가치가 확산되고 지역주민들이 주도하는 관광사업이 활성화되기 위해 서는 지속적으로 주민주도 사업을 관리하고 육성하는 시스템이 필요하다고 답 변함. 이를 위하여 법으로 보장되는 중간지원조직이 필요함을 설명함

- "일반 관광사업체와 주민들이 협력하고 주도하는 소규모 관광사업은 방향 성과 결이 다릅니다. 지역 내에서 관광두레사업이 완료된 이후에도 관광두 레사업 가치가 확산되고 확대되기 위해서는 지속적으로 관리하고 육성할 수 있는 시스템이 필요합니다. 이는 법적으로 보장되는 중간지원조직이 답 이 될 수 있습니다.”(관광두레PD)

- 광역협력지원센터 관계자는 지방자치단체가 조례를 제정해 주민 주도, 지역 기반 관광 사업을 육성할 수 있도록 근거 법이 만들어질 필요가 있다고 응답함

\section{6) 관광두레사업의 안정적 추진과 지속적 성과 도출}

- 관광두레사업 이해관계자 다수는 관광두레사업이 지향하는 목적인 지속가능 한 관광의 실현, 주민 주도 관광을 통한 지역경제 순환, 공동체 의식 향상 등 이 점차 결실을 맺고 있다고 봄. 법적 근거 마련을 통해 성과를 공고히 하고, 더욱 안정적으로 사업을 추진할 수 있도록 할 필요가 있다고 응답함

- "관광두레사업이 지향하는 목표를 위해 사업을 안정적으로 추진하기 위한 발판으로서 법적 근거가 필요합니다.”(광역관광두레협력센터)

- "관광두레사업은 고유의 성과를 내고 있습니다. 지속가능한 관광 발전과 자 생력을 갖춘 지역관광 주체 육성을 위해 법적 근거가 필요합니다.”

(지방자치단체 담당자) 


\section{2. 법 제·개정 시 고려사항}

\section{가. 조문에 포함할 내용에 대한 의견}

- 관광두레사업의 목적 및 개념 정의. 주민 주도에 대한 명확한 정의

- 최소한 중앙정부와 지방자치단체의 정책의사결정자, 사업 참여자들이 관광 두레사업을 체계적으로 이해할 수 있도록 사업의 목적과 정의가 포함될 필 요가 있음

- 관광두레사업의 정체성을 담은 주민 주도, 관광두레 $\mathrm{PD}$ 의 중간지원 또는 코 디네이팅, 지역성(로컬리티), 비즈니스 모델의 혁신성 등의 정의가 포함될 필요가 있음

- 주민사업체, 관광두레협의회 등의 법적 지위 보장 및 지원

- 관광두레사업을 통해 육성한 주민사업체, 관광두레협의회 등에 대한 법적 근거가 필요함

- 주민공동체가 주민사업체로서 창업 및 경영개선 하는 데 필요한 행·재정적 지원 근거가 필요함

- 창업 및 경영개선을 완료한 관광두레 주민사업체의 성장 발전을 위한 지속 지원 근거가 필요함

- 관광두레 주민사업체는 지역의 문제를 해결하고, 주민공동체가 주도한다는 특성을 고려하여 사회적 경제 영역에 포함되어야 함. 사회적 경제 영역에 포 함되어 공공기관 우선구매 등의 혜택을 부여받을 수 있도록 근거가 필요함

- 전문인력(관광두레 $\mathrm{PD})$ 양성 및 활동 지원

- 관광두레PD 및 청년관광두레 PD 선발, 자격, 활동내용 및 범위 등에 대한 근거가 필요함

- 관광두레PD 및 청년관광두레 $\mathrm{PD}$ 활동에 대한 지원 근거가 필요함

- 지역 내·외 조직 및 기관과의 네트워크 주체로서 관광두레 $\mathrm{PD}$ 를 인식할 수 있도록 관련 근거가 필요함

- 총괄지원기관과 중간지원조직 설립 및 운영

- 관광두레사업이 본래의 사업 취지와 목적에 맞게 사업을 추진하고, 더욱 안 
정적인 성장과 발전을 이루기 위해 총괄지원기관을 설립할 필요가 있음. 관 광두레 사업을 총괄할 수 있는 별도의 기관을 두어 노하우가 계승되고, 지 역별 편차 없이 지원할 수 있는 시스템이 확립되어야 함

- 또한 총괄지원기관과 연계하여 광역 및 기초 지방자치단체에서도 중간지원 조직을 설립 및 운영할 수 있도록 근거가 필요함

- 지방자치단체의 역할

- 최소한 관광두레PD 활동 기간 중에는 지방자치단체가 지원할 부분을 정확 히 이행할 수 있도록 법적 근거가 필요함

- 주민사업체 통계

- 관광두레사업의 추진 현황과 주민사업체 통계 등의 자료가 행정적으로 관 리될 수 있도록 할 필요가 있음

- 지자체 유휴공간이나 국·공유자산에 대한 특례

- 주민사업체나 중간지원조직에 대하여는 국가나 지방자치단체가 소유하는 행정재산이나 일반재산의 일부를 이용할 수 있도록 법적 근거를 마련할 필 요가 있음

- 주민사업체에게 공공시설의 운영 등을 위탁할 수 있음을 명시함으로써, 지 역 내 유휴시설을 활용하여 민간의 아이디어와 협력을 결합해 수익을 창출 할 수 있는 기반을 마련할 필요가 있음

\section{나. 법제화 관련 추가 의견}

- 관광두레사업의 고유성 및 정체성을 명확히 할 필요가 있음

- 법제화 방향이 주민사업체에 대한 '규제'보다는 '진흥', '육성'에 초점을 맞출 필요가 있음

- 최대한 빠른 입법이 실현될 수 있도록 현실적이고 실제적인 방안 마련이 필요함

- 법령이 만들어 지더라도 지방자치단체별로 법령을 해석하는 데 있어 차이를 보 일 수 있음. 향후 법에 기반한 명확한 지침과 지원 체계 등을 마련할 필요가 있음 


\section{제3절 시사점}

\section{가. 관광두레사업을 통한 지역관광의 긍정적 변화}

- 2013년부터 추진한 관광두레사업은 지역주민 공동체가 스스로 협력하여 지역 고유의 자원을 활용한 주민사업체를 창업 및 경영개선 하도록 육성하는 사업 으로 2019 년 기준 480 개 지역공동체를 발굴하였고, 이 가운데 110 개 주민사 업체가 창업 및 경영 개선을 완료함

- 전국 곳곳에 주민들이 직접 만들고 경영하는, 기존의 관광상품과 서비스와 차별 화된 콘텐츠가 생겨남에 따라 관광객들은 지역에서 새로운 경험과 만족을 느낌

- 2019년까지 관광두레 주민사업체의 누적 매출액은 426억4천만 원이며, 관광 두레 주민사업체가 지역자원 활용 및 지역 내 순환 등을 추구함을 고려할 때 지역경제에 미친 파급효과는 더욱 클 것임

- 이 밖에도 관광두레사업을 통해 지역주민들이 관광 주체로 성장하고, 관광두 레 $\mathrm{PD}$ 라는 기획자를 양성해 그들이 지역 활성화 주체로 활동하는 등 지역관광 의 인적 역량 강화에 기여함

\section{나. 관광두레사업의 제도적·체계적 성장과 발전에 한계}

- 이상의 긍정적인 변화에도 불구하고 관광두레사업에 대한 근거 법령이 마련되 지 않아 사업 추진 과정에서 다양한 어려움이 발생함. 이에 따라 관광두레사업 및 관광두레 주민사업체의 제도적·체계적 성장과 발전에 한계가 있음

- 관광두레사업은 기존 정형화된 틀에 따라 사업 대상지와 내용 등을 동일하 게 추진하는 사업방식을 지양하고, 단계별·현장밀착형으로 주민사업체를 육성하도록 사업을 설계함. 각 지역의 여건과 상황에 맞게 진행될 수 있도 
록 유연함을 갖추었으나, 이에 대한 법적 근거가 불명확하여 사업 추진에 어려움이 발생함

- 특히 지방자치단체의 역할에 대한 법적 규정이 미비한 점은 지방자치단체의 관광두레사업에 대한 이해와 관심도 차이에 따라 관광두레사업을 지원하고 주 민사업체를 육성하는 데 지자체 간 정책지원 역량의 편차가 크게 나타나고, 연동하여 사업 추진 성과의 차이를 보이는 주요한 원인으로 작용함

- 관광두레사업 추진 과정에서 지자체 관계자, 관광두레PD, 주민사업체는 관광 두레사랑방 지원, 주민사업체 지원, 5차 년도 예산 매칭, 중간지원기관 운영 등에서 어려움을 토로함

- 관광두레사업 추진 과정에서 지방자치단체의 행·재정적 협력 수요가 발생 하여도 법적 근거가 없어 난항을 겪음

- 지역 내·외부에서 관광두레PD의 역할, 활동범위 등에 대한 이해가 부족함

- 관광두레 주민사업체에 대한 법적 근거가 부재해 지방자치단체를 비롯해 타 부문의 지원 및 연계와 협력을 유도하기 어려움

- 관광두레사업의 체계적 성장과 발전을 위해서는 중간지원기관의 운영이 필 요하나, 이를 촉진할 법적 근거가 없음

\section{다. 관광두레사업의 성과 지속 창출 및 체계적 발전을 위한 근거 법령 필요}

- 관광두레사업의 성과 지속 창출을 위해서는 관광두레사업의 고유한 특징과 강 점에 대한 법적 근거가 필요함

- 또한 관광두레사업의 제도적·체계적 발전을 위해서는 현재 법·제도 부재로 인해 발 생하고 있는 추진 과정상의 한계를 검토하고 이를 법령 등에 반영할 필요가 있음 - 지방자치단체 지원 및 조례 제정의 근거이자, 지방자치단체의 적극적 참여와 지 원 의지 고취, 지역 관광자원 활용·연계의 보장, 지역주민과 전문가 등 관광두 레사업 참여 활성화 기반, 주민사업체에 대한 효율적인 관리, 지역 내 주민주도 관광사업의 가치 확산의 지속성 등 측면에서 법제화 필요성이 제기됨 

관광두레 법제화 방안 연구

제3장

관광두레사업 관련 법령

및 유사 사례 분석 



\section{제1절 관광두레사업 관련 법령}

- 현행 관광두레사업은 관광진흥법 제 47 조7과 제 48 조에 근거하고 있음. 본 절 에서는 관광진흥법의 구조 및 내용, 그리고 현행 근거 법령의 한계와 지방자치 단체에서 관광두레사업과 관련하여 제정한 조례를 살펴 봄

\section{1. 관광진흥법}

\section{1. 관광진흥법 구조 및 내용}

\section{가. 관광사업 추진의 기반이 되는 실행 법률}

- 「관광진흥법」은 1986 년 「관광사업법」과 「관광단지개발촉진법」이 폐지 및 통 합되면서 제정된 법률로 관광사업과 관광개발, 그리고 관광진흥 등 실제적으 로 관광분야 전반을 포괄하는 종합법적 성격을 지니고 있음

- 관광진흥법은 관광 여건을 조성하고 관광자원을 개발하며 관광사업을 육성 하여 관광 진흥에 이바지하는 것을 목적으로 함(관광진흥법 제 1 조)

- 또한 많은 관광 사업들이 관광진흥법 조항을 근거로 사업을 추진하여 실행법 적 성격도 가지고 있으나, 우리나라 관광과 관련된 대부분의 사안을 다루고 있으며 많은 내용들이 복잡하게 구조화 되어 있어 세부 사업의 직접적 대응에 는 한계가 있음

\section{나. 광범위한 내용을 포괄하며 다양한 내용이 혼재}

- 「관광진흥법」은 많은 내용을 포함하고 있기 때문에 다른 법률과 비교하여 개정 횟수가 많은 편이며, 이와 더불어 목적과 성격을 달리하는 사업입제와 개발입제 
가 같이 포함되어 있고 진흥업과 규제업도 함께 다루고 있음(류광훈, 2012) - 제 1 장 총칙, 제 2 장 관광사업, 제 3 장 관광사업자 단체, 제 4 장 관광의 진흥과 홍보, 제5장 관광지 등의 개발로 구성됨

- 관광진흥법은 종합법적 성격에 따라 관광사업 발전을 위해 필요한 비전과 목표, 다양한 정책 수단 등에 대한 근거를 제공해야 함에도 불구하고 변화된 여건을 반영할 수 있는 항목이 제한되어 새로운 관광 분야에 대한 근거 법제로서 한계 가 있는 상황임

- 특히 관광 진흥과 관련된 조항은 제 47 조7(관광산업 진흥 사업) 및 제 48 조(관광 홍보 및 관광자원 개발)에 불과하고, 추가되는 내용은 하위 조항으로 설정되고 있어 신규 분야 도입 및 육성에 대한 내용을 담아내기에는 위계상 한계가 있음

\section{다. 관광진흥법 분법화 논의 진행 중}

- 관광법제의 한계를 개선하기 위해 관광진흥법의 분법 등 관광법제 개편에 대 한 논의가 지속적으로 진행 중이었으나, 최근 발생한 코로나 등 외부 위험요인 에 대한 관광 부문의 집중적 대응으로 인해 분법화 논의가 순연되는 상황임. 분법화 진행 사항을 고려하되, 신속한 대응이 요구되는 입법 사안에 대해서는 현행 관광진흥법 일부개정을 검토할 수 있음

- 관광진흥기본계획 2020 시행계획에 제시된 관광진흥법의 분법화 추진(안)과 내용은 다음과 같음

- 관광기본법, 관광진흥법의 분야별·기능별 분법안 최종확정

- 관계부처, 업계, 국회 등 의견조회 및 협의

- 법안 발의 및 국회 심사 추진

- 이 밖에 관광진흥법 분법 추진과 연계하여 지역관광 육성을 위한 제도적 기반 으로서 '가칭, 지역관광진흥법' 제정이 필요하다는 논의도 진행되고 있음 - 지역관광진흥법의 핵심 내용으로서 지역관광을 전담할 지역관광조직의 설 치와 운영, 관련 재원의 확충과 지원, 관광형 사회적 경제를 비롯해 새롭게 등장하는 신사업에 대한 제도적 수용 등을 논의 중임 
[그림 3-1] 관광진흥법 분법화(안)

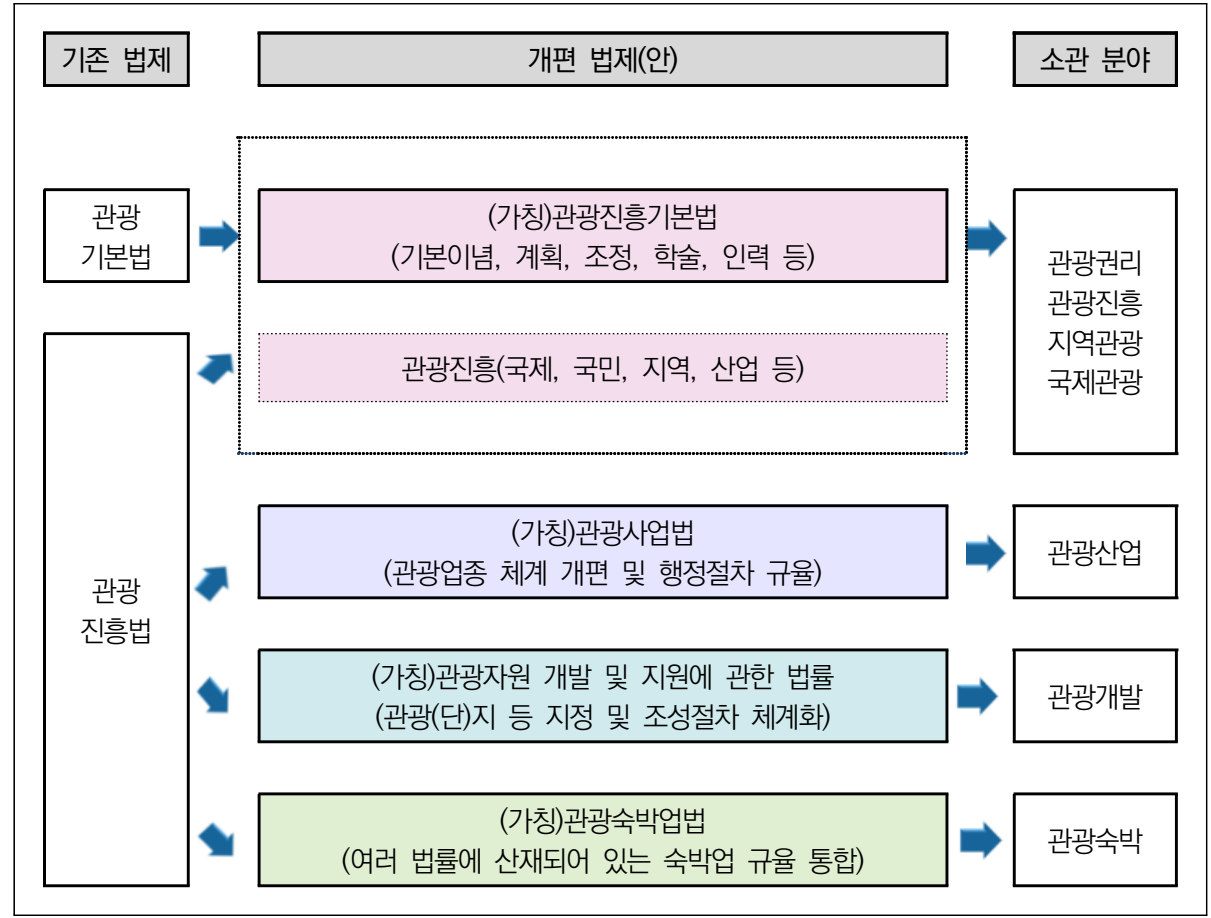

자료: 문화체육관광부, 관광진흥기본계획 2020 시행계획

\section{2. 관광두레사업 관련 조항}

\section{가. 관광진흥법 제 48 조}

- 관광두레사업은 새로운 형태의 지역관광 발전모델로 지역주민들이 직접 참여 한다는 특징과 관광두레PD나 관광두레사랑방과 같이 중간지원 인력 및 공간 이 사업 추진 체계에 포함되어 있다는 점에서 기존 지방자치단체 중심의 관광 정책 사업과는 다른 특성을 나타냄

- 2013년부터 추진한 관광두레사업은 「관광진흥법」 제 48 조에 근거하여 관광 진흥을 위한 사업의 일환으로 추진되어 옴

- 제 48 조제 4 항의 '문화체육관광부장관과 지방자치단체의 장은 관광객의 유 치, 관광복지의 증진 및 관광 진흥을 위하여 대통령령으로 정하는 바에 따 라 다음 각 호의 사업을 추진할 수 있다.'에 근거함 
- 제 3 호 관광상품의 개발, 제 4 호 국민 관광복지 증진, 제 5 호 유휴자원을 활용 한 관광자원화 사업 등을 추진할 수 있는 규정을 두고 있음

- 지역관광 활성화를 위한 노력이 진행되면서 제 48 조의 하위 조항에는 지역축제, 문화관광해설사, 지역관광협의회, 한국관광품질 인증 등 다양한 내용이 포함되 어 있음. 지역관광과 관련된 신규 정책 및 사업을 반영해 조문이 추가되어 옴

〈표 3-1〉 관광진흥법 제48조 하위 조항 내용

\begin{tabular}{l|l}
\hline \multicolumn{1}{c|}{ 내용 } & \multicolumn{1}{c}{ 신설 연월 } \\
\hline $\begin{array}{l}\text { 제48조의2(지역축제 등) } \\
\text { 제48조의3(지속가능한 관광활성화) }\end{array}$ & 본조신설 2009. 3. 25. \\
\hline $\begin{array}{l}\text { 제48조의4(문화관광해설사의 양성 및 활용계획 등) } \\
\text { 제48조의5(관광체험교육프로그램 개발) }\end{array}$ & 본조신설 2011. 4. 5. \\
\hline 제48조의6(문화관광해설사 양성교육과정의 개설·운영) & 전문개정 2018. 12. 11. \\
\hline 제48조의7 삭제 & 2018. 12. 11. \\
\hline 제48조의8(문화관광해설사의 선발 및 활용) & 본조신설 2011. 4. 5. \\
\hline 제48조의9(지역관광협의회 설립) & 본조신설 2015. 5. 18. \\
\hline 제48조의10(한국관광 품질인증) & 본조신설 2018. 3. 13. \\
제48조의11(한국관광 품질인증의 취소) &
\end{tabular}

\section{나. 관광진흥법 제 47 조의 7}

- 2018년12월24일, 관광산업 진흥 사업과 관련하여 제 47 조의7이 신설됨. 이에 따라 문화체육관광부장관은 관광산업의 활성화를 위하여 대통령령으로 정하 는 바에 따라 다음 각 호의 사업을 추진할 수 있게 됨

- 이 가운데 제 2 호의 '관광 관련 창업 촉진 및 창업자의 성장.발전 지원', 제 5 호 의 ‘지역에 특화된 관광 상품 및 서비스 등의 발굴·육성'이 관광두레사업의 근 거 조항으로 볼 수 있음 


\section{「관광진흥법」의 관련 법령}

제47조의7(관광산업 진흥 사업) 문화체육관광부장관은 관광산업의 활성화를 위하여 대통령령으로 정하

는 바에 따라 다음 각 호의 사업을 추진할 수 있다.

1. 관광산업 발전을 위한 정책·제도의 조사·연구 및 기획

2. 관광 관련 창업 촉진 및 창업자의 성장·발전 지원

3. 관광산업 전문인력 수급분석 및 육성

4. 관광산업 관련 기술의 연구개발 및 실용화

5. 지역에 특화된 관광 상품 및 서비스 등의 발굴·육성

6. 그 밖에 관광산업 진흥을 위하여 필요한 사항

제48조(관광 홍보 및 관광자원 개발) (1) 문화체육관광부장관 또는 시·도지사는 국제 관광의 촉진과 국 민 관광의 건전한 발전을 위하여 국내외 관광 홍보 활동을 조정하거나 관광 선전물을 심사하거나 그 밖에 필요한 사항을 지원할 수 있다.

(2) 문화체육관광부장관 또는 시·도지사는 제1항에 따라 관광홍보를 원활히 추진하기 위하여 필요하 면 문화체육관광부령으로 정하는 바에 따라 관광사업자등에게 해외관광시장에 대한 정기적인 조사, 관광 홍보물의 제작, 관광안내소의 운영 등에 필요한 사항을 권고하거나 지도할 수 있다.

(3) 지방자치단체의 장, 관광사업자 또는 제 54 조제 1 항에 따라 관광지·관광단지의 조성계획승인을 받 은 자는 관광지·관광단지·관광특구·관광시설 등 관광자원을 안내하거나 홍보하는 내용의 옥외광고물 (屋外廣告物)을 「옥외광고물 등의 관리와 옥외광고산업 진흥에 관한 법률」의 규정에도 불구하고 대통 령령으로 정하는 바에 따라 설치할 수 있다.

(4) 문화체육관광부장관과 지방자치단체의 장은 관광객의 유치, 관광복지의 증진 및 관광 진흥을 위하 여 대통령령으로 정하는 바에 따라 다음 각 호의 사업을 추진할 수 있다.

1. 문화, 체육, 레저 및 산업시설 등의 관광자원화사업

2. 해양관광의 개발사업 및 자연생태의 관광자원화사업

3. 관광상품의 개발에 관한 사업

4. 국민의 관광복지 증진에 관한 사업

5. 유휴자원을 활용한 관광자원화사업

\section{3. 현행 관광두레사업 근거 법령의 한계}

\section{가. 관광두레사업에 대한 근거 불명확}

- 관광진흥법 제 48 조의제4항, 제 47 조의 7 이 관광두레사업과 관련이 있는 조항 이며, 해당 조문에서 문화체육관광부장관은 “대통령령으로 정하는 바에 따라" 사업을 추진할 수 있다고 명시함. 그러나 관광진흥법 시행령에는 관광진흥법 제 48 조제 4 항과 제 47 조의7에서 위임하고 있는 내용에 대한 조항이 부재함 
- 현행 제 48 조의제 4 항, 제 47 조의7에는 '관광두레' 사업의 명칭이나 '주민 주도 형'과 같이 관광두레사업의 특성이 반영된 내용이 명시되지 않아 직접적 법률 근거로는 부족함

- 법률 전문가들은 현행 관광두레사업의 근거 법령으로 꼽히고 있는 관광진 흥법 제 47 조의 7 및 제 48 조로도 관광두레사업에 대한 지원이 가능한 것으 로 해석하나, 지방자치단체 등이 관광두레사업과 관련한 행위를 하고자 할 때 법적 근거로 해석하는 데 어려움을 표함

\section{나. 관광두레사업의 재정 지원 근거 미흡}

- 관광두레사업은 기본적으로 국비로 집행하나, 주민 주도의 지속가능한 지역관 광 활성화라는 사업 목적의 원활한 달성을 위해서는 지방자치단체의 행·재정 적 지원이 필수적임

- 하지만 관광두레사업과 관련하여 중앙정부와 지방자치단체 간의 업무 배분에 대한 법적 근거가 불명확하여, 지방자치단체의 재정 지원을 담보하기 어려움

- 더욱이 관광진흥법」 제 47 조의 7 제 2 호와 제 5 호에 따르면 문화체육관광부장관 은 관광 관련 창업 촉진 및 창업자의 성장발전 지원, 지역에 특화된 관광 상품 및 서비스 등의 발굴육성 추진할 수 있다고 되어 있어 지방자치단체가 관련 지원을 할 수 있는 근거가 없음

- 또한 관광진흥법 제76조(재정지원) 조항을 근거로 지방자치단체, 관광사업자 단체 또는 관광사업자에게 보조금을 지급할 수 있음. 하지만 관광두레사업은 지방자치단체로 보조금을 지원해 지방자치단체가 예산을 매칭해 집행하는 구 조가 아니며, 관광두레 주민사업체의 경우 관광진흥법에서 명시한 관광사업자 가 아닌 경우가 많아 관광두레사업과 관련하여 지방자치단체가 재정을 지원할 근거가 부족함 


\section{2. 지방자치단체 조례}

\section{1. 광역시·도 단위}

\section{가. 전라남도 주민 주도 관광사업 육성 및 지원 조례 제정 배경}

- 광역시·도 가운데 전라남도가 유일하게 관광두레사업 관련 조례를 제정함. 전 라남도는 2014년 곡성군, 여수시 등을 시작으로 관광두레사업을 추진해 왔으 며, 지역별 관광두레 현황을 보면 광역시·도 가운데 가장 높은 주민사업체 수 비율을 나타냄

- 2019년 관광두레사업에 참여한 전국 주민사업체 192 개 가운데 $17.2 \%$ 에 해당하는 33 개가 전라남도의 주민사업체임

- 특히 2019년 관광두레사업의 일환으로 전남도, 경북도, 경남도를 관광두레 지역협력사업 사업지로 선정하고 광역관광두레협력지원센터를 운영하기 시작 하면서, 전남도 단위에서 관광두레사업의 추진 체계를 뒷받침할 수 있는 조례 제정 필요성이 제기됨

- 관광두레사업은 공모를 통해 사업 대상지를 선정하고 중앙정부 및 중앙 전 담지원기관이 운영하다보니, 각 지역별 특성과 수준에 대한 고려가 부족함

- 관광인프라 취약지역이나 관광두레사업 종료지역 관리·지원, 전문 교육을 통한 전문 인력 및 혁신리더 양성, 지역 특화형 주민사업체 창업 지원 강화, 단계별 멘토링 지원시스템 구축을 통한 인큐베이팅 체계 강화 등 중앙정부 의 관광두레사업을 보완하고, 지역차원의 관리·지원을 위한 제도적 방안 마 련이 필요함

- 이에 전라남도는 「지방자치법」 제22조제9조제2항제3호파목에 명시되어 있는 '지역특화산업의 개발과 육성·지원'을 법적 근거로, 지역 미래 성장 동력으로 관광산업이 지속가능한 발전과 활성화를 구현할 수 있도록「전라남도 주민 주 도 관광사업 육성 및 지원 조례」를 제정하여 제도적인 지원을 하고자 함

- ‘관광두레’라는 직접적인 사업 명칭 대신 ‘주민 주도 관광사업’이라는 포괄 적인 명칭을 사용해「전라남도 주민 주도 관광사업 육성 및 지원 조례」를 2020년5월21일(조례 제5075호)에 제정함 


\section{나. 전라남도 주민 주도 관광사업 육성 및 지원 조례 주요 내용}

- 해당 조례는 총 12 조로 구성되어 있으며, 주민 주도형 관광사업에 대한 목적 (제1조) 및 정의(제2조), 사업 지원(제7조), 협력체계 구축(제8조), 주민 참여 (제9조), 사무의 위탁(제10조) 등 주민 주도형 관광사업 육성과 지원을 위한 체계적인 구성을 갖추고 있음

- 제 2 조 정의에 주민 주도형 관광사업이란 지역관광객을 대상으로 지역주민 고 용과 소득창출을 위하여 자발적-협력적으로 경영하는 관광사업으로 명시함으 로써, 주민들의 자발적·협력적 관광 경영에 기초한 관광두레사업의 고유 특성 을 반영함

- 한편 공모를 통해 사업 대상지역을 선발하는 구조를 보완하여, 전라남도의 특 수성을 반영한 주민 주도 관광사업 육성을 위해 제7조 사업 지원 부분에 "관 광두레사업 제외지역 관리"에 대한 내용을 포함함

- 또한 광역관광두레협력지원센터와 같은 주민 주도형 관광사업에 대한 중간지 원조직 운영을 위해 제 10 조(사무의 위탁)에 "도지사는 이 조례에 따른 사무를 효율적으로 처리하기 위하여 필요한 경우 사무의 일부 또는 전부를 「전라남도 사무의 민간위탁 조례」에 따라 지역 관광 관련 법인단체 또는 기관이나 개인 에게 위탁할 수 있다.”는 근거 조항을 마련함

\section{「전라남도 주민 주도 관광사업 육성 및 지원 조례」}

제1조(목적) 이 조례는 지역 주민이 주체적으로 운영하는 관광사업의 육성 및 지원에 필요한 사항을 규정함으로써 지속가능한 지역 관광을 실현하는 데 목적이 있다.

제2조(정의) 이 조례에서 사용하는 “주민 주도 관광사업”이란 지역 관광객을 대상으로 지역 주민이 고용 과 소득창출 등을 위해 자발적·협력적으로 경영하는 관광사업을 말한다.

제3조(도지사의 책무) (1) 전라남도지사(이하 “도지사"라 한다)는 주민 주도 관광사업의 육성 및 지원을 위하여 다양한 시책을 마련하고 추진하여야 한다.

(2) 도지사는 지역 주민 및 주민사업체의 적극적인 참여와 민간 자원봉사자 등의 협력을 촉진시키기 위하여 노력하여야 한다.

제4조(적용 범위) 이 조례는 전라남도(이하 “도”라 한다)에 거주하며 지역 관광자원을 활용하여 관광 사업을 운영하는 법인단체 또는 기관, 개인에게 적용한다. 
제5조(기본계획 수립) (1) 도지사는 주민 주도 관광사업을 체계적·효율적으로 추진하기 위하여 5년마다 전라남도 주민 주도 관광사업 기본계획(이하 “기본계획”이라 한다)을 수립·시행하여야 한다.

(2) 기본계획에는 다음 각 호의 사항이 포함되어야 한다.

1. 기본방향 및 정책 목표

2. 인적 자원 조성 및 육성 방안

3. 주민사업체 지원 방안

4. 주민 주도 관광 상품 및 프로그램 개발·운영

5. 국내외 협력체계 구축

6. 지속 가능한 발전을 위한 제도 개선

7. 평가 및 환류체계 수립

8. 그 밖에 주민 주도 관광사업의 육성 및 지원을 위하여 도지사가 필요하다고 인정하는 사항 (3)「관광진흥법」제49조제2항에 따른 전남권 관광개발계획에 제2항 각 호의 사항이 포함된 경우 주 민 주도 관광사업 육성 및 지원계획이 수립된 것으로 본다.

제6조(실태조사) (1) 도지사는 기본계획 수립을 위하여 필요한 경우에 주민 주도 관광사업에 대하여 실 태조사를 할 수 있다.

(2) 도지사는 실태조사를 효과적으로 수행하기 위하여 주민 주도 관광사업 및 지역 관광 관련 연구기 관 또는 단체 등에 실태조사를 의뢰할 수 있다.

제7조(사업 지원) (1) 도지사는 주민 주도 관광사업의 육성 및 지원을 위하여 다음 각 호의 사업을 추진 할 수 있다.

1. 지역자원 활용 콘텐츠 개발

2. 전문 인력 양성 교육 강화

3. 연계관광 프로그램 발굴운영

4. 관광두레사업 제외지역 관리

5. 주민사업체 발굴 및 활성화

6. 지역자원 조사연구

7. 체계적인 홍보시스템 구축

8. 그 밖에 주민 주도 관광사업 육성 및 지원에 도지사가 필요하다고 인정하는 사업

(2) 도지사는 제1항에 따른 주민 주도 관광사업을 수행하는 법인단체 또는 기관, 개인에게 예산의 범 위에서 필요한 경비를 지원할 수 있다.

제8조(협력체계 구축 등) (1) 도지사는 주민 주도 관광사업 육성 및 지원을 위하여 다른 지방자치단체, 전라남도교육청, 그 밖의 관련 기관 및 단체 등과 적극 협력하여야 한다.

(2) 도지사는 필요할 경우 제1항에 따른 기관 및 단체 등과 주민 주도 관광사업 지원을 위한 협약 등을 체결할 수 있다.

제9조(주민참여) (1) 도지사는 주민 주도 관광사업 육성에 관하여 주민참여 방안을 적극적으로 마련하여 야 한다.

(2) 주민은 도지사에게 주민 주도 관광사업에 관하여 의견을 제출할 수 있다.

(3) 도지사는 제 2 항에 따라 주민 주도 관광사업에 관하여 의견을 제출받은 경우 그 타당성을 검토하여 제5조 및 제7조에 반영할 수 있다. 
제10조(사무의 위탁) 도지사는 이 조례에 따른 사무를 효율적으로 처리하기 위하여 필요한 경우 사무의 일부 또는 전부를「전라남도 사무의 민간위탁 조례」에 따라 지역 관광 관련 법인·단체 또는 기관이나 개인에게 위탁할 수 있다.

제11조(포상) 도지사는 주민 주도 관광사업의 육성에 기여한 공이 뛰어난 개인·기업.단체 또는 공무원 등을「전라남도 포상 조례」에 따라 포상할 수 있다.

제12조(시행규칙) 이 조례의 시행에 필요한 사항은 규칙으로 정한다.

$$
\text { 부 칙 (2020. 5. 21.) }
$$

이 조례는 공포한 날부터 시행한다.

\section{2. 기초지방자치단체 단위}

\section{가. 의정부시 관광 진흥 조례}

- 대부분의 지자체들이 관광 진흥 조례를 제정하여 운영하고 있으나, 현재 기초 지방자치단체 조례로 관광두레사업에 대한 내용을 포함하고 있는 경우는 의정 부시가 유일함

- 더욱이 의정부시는 관광두레사업 대상지역이 아님에도 불구하고, 2018년3월 15 일 “의정부시 관광 진흥 조례”를 제정(경기도의정부시조례 제2845호)하면 서 관광두레사업을 추진하는 관광사업자 단체 또는 관광사업자를 지원할 수 있는 조항을 포함함

- 제2조(정의)제3호에 “관광두레”란 지역주민이 주체적·자발적·협력적으로 관광 사업을 운영하여 일자리와 수익을 창출하는 관광경영 형태를 말한다 고 명시함

- 제5조(관광객 유치 지원 등) 제1항에 시장은 관광객 유치 또는 관광사업의 육성을 위하여 다음 각호의 어느 하나에 해당하는 사업을 추진하는 관광사 업자 단체 또는 관광사업자를 지원할 수 있다고 규정하고, 제3호에 관광두 레사업을 추진하는 경우를 포함함 
- 관광사업자 단체 및 관광사업자에 대한 지원 내용은 "관광객 유치 등에 필 요한 각종 자료 및 정보 등의 제공”, “보조금 지급”, “공유 재산 임대료의 100 분의 30감면”, “그 밖에 관광 진흥에 필요하다고 시장이 인정하는 사 항” 등임

\section{「의정부시 관광 진흥 조례」}

제2조(정의) 이 조례에서 사용하는 용어의 뜻은 다음과 같다.

1. “관광상품”이란 관광자원을 활용하여 관광객을 유치할 수 있도록 만든 관광코스를 말한다.

2. “시티투어"란 관광객 유치향상을 위해 의정부시(이하 "시”라 한다)의 관광지·문화유적지·체험시 설·지역축제장 등 주요 관광 명소를 경유하는 관광 상품을 말한다.

3. “관광두레”란 지역주민이 주체적-자발적·협력적으로 관광 사업을 운영하여 일자리와 수익을 창출 하는 관광경영 형태를 말한다.

제5조(관광객 유치 지원 등) (1) 시장은 관광객 유치 또는 관광사업의 육성을 위하여 다음 각 호의 어느 하나에 해당하는 사업을 추진하는 관광사업자 단체 또는 관광사업자를 지원할 수 있다.

1. 관광객을 유치하기 위하여 관광 상품을 개발·판매하는 경우

2. 관광기념품, 시에서 생산·제조되는 지역특산품을 개발하고 홍보·판매하는 경우

3. 관광두레 사업을 추진하는 경우

4. 그 밖에 관광객 유치 또는 관광사업의 육성을 위하여 지원이 필요하다고 시장이 인정하는 경우

(2) 제 1 항에 따른 지원내용은 다음 각 호와 같다.

1. 관광객 유치 등에 필요한 각종 자료 및 정보 등의 제공

2. 제 5 조제 1 항 각 호의 어느 하나에 해당하는 사업의 추진에 따른 보조금 지급

3. 「관광진흥법」(이하 “법”이라 한다) 제76조제3항 및「관광진흥법 시행령」(이하 “영”이라 한다) 제 64 조의2제1항에 따라 관광지등의 사업시행자에 대하여 공유 재산 임대료의 100 분의 30 감면

4. 그 밖에 관광 진흥에 필요하다고 시장이 인정하는 사항

(3) 제2항에 따른 지원조건, 규모, 방법 등에 관한 세부적인 사항은 시장이 따로 정할 수 있다.

\section{나. 안성시 관광 진흥 조례 전부개정(안)}

- 안성시는 2019년 관광두레사업 대상지역으로 신규 선정되었으며, 2020년 2 년차 사업 지역임. 현재 안성시 관광 진흥 조례 전부개정을 추진 중이며, 전부 개정(안)에 “주민주도 관광사업” 및 “관광두레사업 지원” 등을 명시함

- 관광두레사업을 추진하면서 중간지원자인 관광두레 $\mathrm{PD}$ 의 역할과 필요성, 그리고 주민사업체에 대한 지원 필요성 등을 인지함에 따라, 지원 근거 마 련을 위해 조례 개정을 추진함 
- 제 2 조(정의)에 “주민주도 관광사업”이란 지역 관광객을 대상으로 지역 주민이 고용과 소득창출 등을 위해 자발적·협력적으로 경영하는 관광사업을 말한다고 규정하고, 제5조(관광종합계획)에서 관광종합계획 수립·시행 시 주민주도 관 광 상품 개발 및 주민주도사업체 지원에 관한 사항을 포함하도록 함

- 특히 제 10 조(주민주도 관광사업 지원)를 통해 시장이 주민주도 관광사업의 육 성 및 지원을 위하여 다양한 시책을 마련하고 추진하여야 한다고 명시함. 이 때 추진할 수 있는 각호의 사업 가운데 “관광두레사업 지원"을 규정함

- 예산 지원과 관련해서도 주민 주도 관광사업을 수행하는 법인·단체 또는 기 관, 개인에게 예산의 범위에서 필요한 경비를 지원할 수 있다고 규정함으로써 주민 주도 관광사업을 수행하는 중간지원조직과 같은 단체, 관광두레 $\mathrm{PD}$, 관 광두레주민사업체 등에게 필요한 경비를 지원할 수 있는 근거를 마련함

\section{「안성시 관광 진흥 조례 전부개정안}

제2조(정의) 이 조례에서 사용하는 용어의 뜻은 다음과 같다.

...

\section{4. “주민주도 관광사업”이란 지역 관광객을 대상으로 지역 주민이 고용과 소득창출 등을 위해 자발적·협 력적으로 경영하는 관광사업을 말한다.}

제5조(관광종합계획) (1) 안성시장(이하 “시장”이라 한다)은 안성시(이하 “시”라 한다)의 관광자원을 효율적 으로 개발하고 관리하기 위한 종합계획(이하 “관광종합계획"이라 한다)을 수립·시행 한다.

(2) 관광종합계획에 포함되어야 할 사항은 다음 각 호와 같다.

1. 관광진흥의 목표와 전략에 관한 사항

2. 국내외 관광여건과 관광동향에 관한 사항

3. 관광정책과제 발굴 및 추진계획에 관한 사항

4. 관광산업 발전을 위한 재원확보에 관한 사항

5. 관광기반시설 확충 및 여건개선에 관한 사항

6. 관광자원 보호·개발·이용·관리 등에 관한 사항

7. 관광상품 개발 및 홍보에 관한 사항

8. 관광인력의 육성 및 업무역량 강화 교육에 관한 사항

9. 주민주도 관광 상품 개발 및 주민주도사업체 지원에 관한 사항

10. 그 밖에 관광산업 발전을 위하여 필요한 사항

(3) 시장은 관광종합계획을 수립할 경우 관련 전문가 및 관광 관련 기관·단체, 시민등의 의견을 수렴할 수 있다.

제10조(주민주도 관광사업 지원) (1) 시장은 주민 주도 관광사업의 육성 및 지원을 위하여 다양한 시책을 마련하고 추진하여야 한다. 


\section{「안성시 관광 진흥 조례 전부개정안}

(2) 시장은 주민주도 관광사업의 육성 및 지원을 위하여 다음 각 호의 사업을 추진할 수 있다.

1. 지역자원 활용 콘텐츠 개발

2. 전문 인력 양성 교육 강화

3. 연계관광 프로그램 발굴·운영

4. 관광두레사업 지원

5. 주민사업체 발굴 및 활성화

6. 지역자원 조사.연구

7. 체계적인 홍보시스템 구축

8. 그 밖에 주민 주도 관광사업 육성 및 지원에 시장이 필요하다고 인정하는 사업

(2) 시장은 제1항에 따른 주민 주도 관광사업을 수행하는 법인-단체 또는 기관, 개인에게 예산의 범위에 서 필요한 경비를 지원할 수 있다.

자료: 안성시 내부 자료(2020년10월14일 자) 


\section{제2절 유사 사례}

- 본 절에서는 지역주민이 각종 지역자원을 활용한 수익사업을 통해 공동의 지 역문제를 해결할 수 있도록 육성한다는 측면에서 관광두레사업과 성격이 유사 하며, 직접적 근거 법령 없이 시행 지침에 근거해 매년 사업을 추진 중인 '마 을기업 육성사업'을 대상으로 법률 제정 필요성과 법률(안) 등을 분석함

\section{1. 마을기업육성지원법(안) 제정 필요성}

\section{가. 마을기업 육성 사업 개요}

- 행정안전부는 2010년 시범 도입한 '자립형 지역공동체사업'을 2011년부터 안정적 일자리 창출에 보다 중점을 둔 '마을기업 육성사업'으로 발전시킴

- 마을기업이란 지역주민이 각종 지역자원을 활용한 수익사업을 통해 공동의 지역문제를 해결하고, 소득 및 일자리를 창출하여 지역공동체 이익을 효과 적으로 실현하기 위해 설립·운영하는 마을단위의 기업을 의미함(행정안전 부, 2020: 1)

- 사업 목적은 지역주민 주도로 지역자원을 활용한 수익사업을 통해 소득 및 일자리 창출과 지역공동체 활성화를 위한 마을단위 기업을 육성하는 것임

- 마을기업은 지역주민 5 인 이상이 출자한 법인이며, 마을기업으로 지정 시 3년 간 1 억 원을 지원 받음

- (지정절차) 시·군·구(신청, 접수) $\rightarrow$ 시·도(심의, 추천 $) \rightarrow$ 행안부(심의, 최종 선정, 지정)

- (평가) 공동체성, 공공성, 기업성, 지역성의 네 가지 요건을 평가하여 선정 
- (지원내용) 3 년 간 1 억 원의 보조금을 지원하며 보조금은 제품개발, 교육, 컨설팅 등의 경상적 경비에 쓰임. 손실금 충당 및 재투자를 위해 순이익의 $40 \%$ 이상을 적립하도록 함 7$)$

- 마을기업으로 지정되지 않더라도 시·도 광역자치단체에서 예비마을기업 제도 를 마련하여 마을기업의 전 단계로써 1 천만 원 이하의 금액을 지원함

- 2010년 '자립형 지역공동체시범사업'에서 184 개 단체를 선정 및 지원하였으 며 2011년 508개, 2012년에 787개, 2013년에 1,024개로 증가하였으며 2020년 4월 기준으로 1,629 개(누적) 마을기업이 운영되는 등 전체 규모가 증 가하였음

- 현재 마을기업 육성 사업은 매년 “마을기업 육성사업 시행 지침"에 근거해 추 진되고 있음

- 행정안전부에서는 매년 마을기업 육성사업 시행 지침을 배포함

- 지침에는 마을기업과 육성사업의 이해(정의, 신청절차 및 심사기준 등), 마 을기업의 관리(마을기업 지정·약정 체결 및 변경, 사업비 지원·집행 및 정 산 등), 기관별 역할 및 평가 등 세부 내용이 포함되어 있음

\section{나. 법률 제정 필요성}

1) 의안원문(마을기업육성지원법안)의 제안 사유

- 20대 국회에서 제안된 '마을기업육성지원법안' 원문에는 지역경제가 침체되 고 일자리가 감소하는 등의 문제가 발생하고 있어 이에 대한 해결 방안으로 지역공동체 회복과 활성화 등을 통한 자립 생태계 구축이 필요한 상황이라고 제시되어 있음

- 또한 마을기업 육성사업의 성과에도 근거 법령 부재로 제도적, 체계적 성장과 발전에 한계가 있으며, 마을기업의 체계적 육성과 안정적 성장 기반을 조성하

7) 투자유형(초기투자형, 후기투자형)에 따라 1차년과 2차년 지원 금액 규모가 다름. 초기투자형은 1차 년도 5 천만 원, 2 차 년도 3 천만 원, 3 차 년도 2 천만 원을 지원하고, 후기투자형은 1차 년도 3천만 원, 2 차 년도 5 천만 원, 3 차 년도 2 천만 원임. 
고, 지속가능한 사업으로 발전시켜 지역 일자리 창출, 지역 경제 활성화 등을 통한 주민의 삶의 질 보장과 지역 공동체 활성화를 위한 구조 조성을 목적으로 한다고 제시함

- 21대 입법안에서도 이와 유사한 내용이 제시되어 있으며, 중앙정부 차원에 서 국가균형발전을 위한 노력이 진행되고 있다는 상황적 설명이 추가되었음

- 요컨대 마을기업 육성사업의 성과를 설명하고, 근거 법령 마련을 통해 마을기 업의 체계적 육성과 안정적 성장 기반을 조성하여 지역 일자리 창출 및 지역 경제 활성화 등을 통한 주민의 삶의 질 보장과 지역 공동체 활성화를 이루고자 함을 법률 제안 이유로 제시함

\section{「20대 국회 법안 제안 이유」}

최근 지역경제가 침체되고 일자리가 감소하는 등의 문제가 발생하고 있는 상황에서 이에 대한 해결 방 안으로 지역공동체 회복과 활성화 등을 통한 자립 생태계 구축이 필요한 상황임.

2010년 12월 「마을기업 육성계획」을 수립한 후 2011년부터 본격 추진한 마을기업은 지역주민이 각종 지역자원을 활용한 수익사업을 통하여 지역문제를 해결하고 소득과 일자리 창출, 지역 공동체 활성화를 도모하는 사업으로 2018년 기준 전국 17개 시도에 1,514개 마을기업이 운영되고 있으며, 2017년 말 기준 17,438 명의 고용, 1,599 억 원의 매출을 올리는 등 성과를 내고 있고, 20 여개소의 마을기업은 연매출 10억 원 이상을 올리고 있는 등 지역사회에 긍정적 영향을 미치고 있음.

그러나 이러한 긍정적 영향에도 불구하고 마을기업에 대한 근거 법령이 마련되어 있지 않아 제도적, 체계 적 성장과 발전에 한계가 있는 상황임. 이에 「마을기업육성지원법」을 제정하여 마을기업의 체계적 육성, 안정적 성장 기반을 조성하고, 지속가능한 사업으로 성장, 발전시킴으로써 지역 일자리 창출, 지역 경제 활성화 등을 통한 주민의 삶의 질을 보장 및 지역 공동체 활성화를 위한 구조를 조성하려는 것임.

\section{$\ulcorner 21$ 대 국회 법안 제안 이유}

중앙정부 차원에서 국가균형발전을 위한 노력이 추진되고 있으나 지역경제가 침체되고 일자리가 줄어드 는 등의 지역공동화 현상이 계속 되고 있는 상황에서 이에 대한 해결 방안으로 지역공동체 회복과 활성 화 등을 통한 지역 내 자립 생태계를 구축할 필요가 있음.

2010년 12월 「마을기업 육성계획」을 수립한 후 2011년부터 본격 추진한 마을기업은 지역주민이 각종 지역자원을 활용한 수익사업을 통하여 지역문제를 해결하고 소득과 일자리 창출, 지역 공동체 활성화를 도모하는 사업으로 2020 년 4월 기준 전국 17 개 시도에 1,629개 마을기업이 운영되고 있으며, 2018년 말 기준 19,261 명의 고용, 1645 억 원의 매출을 올리는 등 성과를 내고 있고, 10 여개소의 마을기업은 연매출 20억 원 이상을 올리고 있는 등 지역사회에 긍정적 영향을 미치고 있음. 


\section{「21대 국회 법안 제안 이유」}

그러나 이러한 긍정적 영향에도 불구하고 마을기업에 대한 근거 법령이 마련되어 있지 않아 제도적, 체계 적 성장과 발전에 한계가 있는 상황임. 이에 「마을기업육성지원법」을 제정하여 마을기업의 체계적 육성, 안정적 성장 기반을 조성하고, 지속가능한 사업으로 성장, 발전시킴으로써 지역 일자리 창출, 지역 경제 활성화 등을 통한 주민의 삶의 질을 보장 및 지역 공동체 활성화를 위한 구조를 조성하려는 것임.

\section{2) 법률 제정 필요성8)}

- 법률 제정 필요성으로는 다음과 같은 내용이 제기됨

- 첫째, 사회적 경제 조직 중 유일하게 독자적 근거법이 부재한 마을기업에 법적 지위를 부여하여 안정적인 성장 기반을 조성할 필요가 있음

- 근거 법이 있는 사회적경제조직으로는 사회적기업(사회적기업육성법 2007년), 협동조합(협동조합기본법 2012년), 자활기업(국민기초생활보장법 2012년) 을 사례로 제시함

- 한편 다양한 사회적경제조직을 포괄하는 공통 법적 토대를 마련한다는 「사 회적경제기본법안」이 21대 국회에서 지속적으로 발의되고 있기 때문에, 왜 마을기업 독자적으로 법률을 제정할 필요가 있는 지가 쟁점이 될 수 있음9)

- 둘째, 지역자원을 활용한 수익사업을 통해 지역문제 해결, 일자리 창출 등 지 역공동체 이익을 실현하고 지역사회로 수익을 환원하는 마을 공동체내 순환구 조를 마련하기 위한 제도적 근거가 필요함

- 셋째, 마을기업들의 추진 시기가 10 년이 지나면서 초기 취·창업 지원에서 벗 어나 성장단계별 맞춤형 자립지원이 필요함. 실효성 있는 지원 정책 추진을 위해 법적 근거가 필요함

- 자립 5년 후 지정취소가 34\%에 달하는 등 폐업률이 높아 지속적인 지원이 필요한 상황이지만 법적 근거가 부재하여 경영안정을 위한 신규 정책 발굴, 예산 협의 등에 어려움이 있음

8) 관련 연구 결과와 행정안전부 내부 자료를 토대로 정리함

9) 사회적경제기본법안 관련하여 윤호중의원 대표발의(의안번호 제 2101880 호), 강병원의원 대표발의(의안번 호 제2102535호), 김영배의원 대표발의(의안번호 제2104663호) 등이 진행 중임 
- 넷째, 마을기업은 사회적경제조직 관련법(사회적기업 육성법」 등)에 명시되어 시행 중인 우선 구매, 조세감면 혜택 등의 지원에서 배제되면서 상대적 소외감 이 발생하여 지역사회에서 마을기업 지원 내실화를 위해 법률 제정을 요구함

- 다섯째, 부처·지자체별로 추진하고 있는 마을기업 관련 정책을 조정하고 지원 하는 통합적인 법적 근거 마련이 필요함. 현재 국토교통부 '도시재생법'의 마 을기업, 산림청 마을기업, 지자체(전남, 순천) 마을기업 등이 있음

- 도시재생 활성화 및 지원에 관한 특별법(약칭: 도시재생법)에서는 "마을기업" 이란 지역주민 또는 단체가 해당 지역의 인력, 향토, 문화, 자연자원 등 각종 자원을 활용하여 생활환경을 개선하고 지역공동체를 활성화하며 소득 및 일 자리를 창출하기 위하여 운영하는 기업을 말한다고 규정하고, 마을기업의 창 업 및 운영 지원 등을 도시재생센터에서 할 수 있도록 하는 등의 내용을 담음 - 산림청은 국유림을 임대하거나 지방자치단체와 공동산림사업, 국유림의 보 호협약을 통한 임산물 양여 등을 통해 마을기업-사회적기업 등을 육성하는 정책을 2018년부터 추진함(양승희, 2018)

- 행정안전부와 전남도는 “지역특화형 마을기업 육성사업 업무협약”을 체결 하고 낙안면 일대에 마을기업을 집중 육성하는 사업을 추진함. 한편 전남 순천시는 2016년부터 순천형 마을기업을 육성함

- 마지막으로 현재 지침으로 운영되고 있으나 법령 제정을 통해 관련 예산편성 의 유연성 확보와 법적 근거를 지닌 전문 지원기관(중간지원조직, 마을기업지 원기관 등)의 설립으로 마을기업 지원의 내실화 요구를 실현하고자 함

\section{2. 마을기업육성지원법(안) 주요 내용}

\section{가. 법제화 추진 과정}

- 마을기업 육성 사업이 2011년부터 지침에 의거해 추진되어 옴에 따라, 행정 안전부는 2015년 한국법제연구원에 법제분석지원을 신청해 '마을기업 육성 관련 법제 분석'을 진행함 
- 본 연구는 마을기업육성사업 시행지침을 상향하여 입법할 수 있도록 법제 화 방안 마련을 목적으로 함

- 이후에도 법제화 필요성 등이 꾸준히 제기됨에 따라 행정안전부는 2019년 6 개월간 '마을기업 육성 지원에 관한 법률안 및 동법 시행령 제정 연구' 용역을 진행하였으며, 같은 해 7월 마을기업육성법 제정 토론회를 개최함

- 국회에서는 2019년 5월 박정 의원의 대표 발의를 통하여 해당 법안이 상정되 었으나 2020년 6월 21대 국회가 개원하면서 임기 만료로 폐기됨

- 21대 국회에서 다시 상정되어 소관위원회에서 논의가 이루어지고 있음 - 2020년6월1일 법률안이 제안되었으며, 2020년9월10일 국회 행정안전위 원회에 상정한 상태임

〈표 3-2〉 마을기업육성사업의 법제화 추진 과정

\begin{tabular}{|c|c|c|c|c|}
\hline 구분 & 법률안명 & 제안자 & 소관위원회 & 진행 과정 \\
\hline 행정안전부 & \multicolumn{4}{|c|}{ - "마을기업 육성 관련 법제 분석』 법제분석지원 연구(신청기관: 행정안전부) (‘15.9) } \\
\hline 행정안전부 & \multicolumn{4}{|c|}{ - 마을기업 육성 지원에 관한 법률안 및 동법 시행령 제정 연구』 용역 진행('19.5.1-10.31.) } \\
\hline 행정안전부 & \multicolumn{4}{|c|}{ - 『마을기업육성지원법』제정 토론회 개최(‘19.7.5.) (제2회 대한민국 사회경제적 박람회) } \\
\hline $\begin{array}{c}\text { 20대 국회 } \\
\text { (2016 } \\
\text { 2020년) }\end{array}$ & $\begin{array}{c}\text { 마을기업육성 } \\
\text { 지원법안 }\end{array}$ & $\begin{array}{l}\text { 박정 의원 } \\
\text { 등 } 10 \text { 인 }\end{array}$ & $\begin{array}{l}\text { 행정안전 } \\
\text { 위원회 }\end{array}$ & \begin{tabular}{|l} 
- 법률안 제안('19.5.15.) \\
- 행정안전위원회 회부('19.5.16.) \\
- 행정안전위원회 상정('19.11.11.) \\
- 제371회 국회(정기회) 제10차 전체 회의에서 \\
상정/제안 설명/검토보고/대체설명 등 \\
('19.11.11.) \\
- 국회 임기만료로 폐기('20.5.29.)
\end{tabular} \\
\hline $\begin{array}{c}\text { 21대 국회 } \\
\text { (2020 } \\
\text { 2024년) }\end{array}$ & 동일 & $\begin{array}{l}\text { 박정 의원 } \\
\text { 등 } 18 \text { 인 }\end{array}$ & $\begin{array}{l}\text { 행정안전 } \\
\text { 위원회 }\end{array}$ & $\begin{array}{l}\text { - 법률안 제안 ('20.6.1.) } \\
\text { - 행정안전위원회 회부('20.6.29.) } \\
\text { - 행정안전위원회 상정('20.9.10.) } \\
\text { - 제382회 국회(정기회) 제2차 전체 회의에서 } \\
\quad \text { 상정/제안설명/검토보고/대체설명 등('20.9.10.) }\end{array}$ \\
\hline
\end{tabular}

\section{나. 마을기업육성지원법(안) 구성 및 주요 내용}

- “마을기업육성지원법안" 은 일반적인 지원법의 조문 구성과 장절 체계를 따라 총칙, 추진체계, 지원 내용, 기반조성, 보칙 등 5개 장으로 이루어짐 - 제 1 장 총칙, 제 2 장 마을기업 육성 추진체계, 제3장 마을기업의 지정 및 육 
성, 제4장 마을기업 육성 기반 조성, 제5장 보칙

- 총칙에는 목적, 정의, 국가 및 지방자치단체의 책무, 마을기업의 역할과 의

무, 다른 법률과의 관계 등을 담음

- 마을기업 육성 추진체계에는 종합계획의 수립, 시·도별 지원계획, 실태조 사, 마을기업육성위원회, 시·도별 마을기업육성위원회 등 계획과 조사, 마 을기업 육성 추진주체에 대한 내용을 포함함

- 마을기업의 지정 및 육성에는 마을기업의 지정, 마을기업에 대한 지원, 조 세감면 및 사회보험료의 지원, 마을기업의 지정취소 등을 담음

- 마을기업 육성 기반조성에는 마을기업의 사업, 지원기관, 포상, 감독, 권한. 업무의 위임·위탁 등의 내용을 포함함

- 마지막으로 보칙에는 과태료와 관련한 사항을 담음

- 20대 국회 제안(2019년)에서는 본칙 21 개 조문과 부칙 4 개 조문으로 구성되 어 있었으나, 21 대 국회 제안(2020년)에서는 제 16 조의 마을기업진흥원이 삭 제되어 본칙 20개 조문과 부칙 4개로 구성됨

- 제 16 조의 마을기업진흥원의 경우 사회적기업진흥원이 역할을 하고 있음에 따라 중복성 등이 법제화 쟁점이 될 수 있어 제외함

- "마을기업육성지원법안"의 주요 내용은 다음과 같음

- 가. 이 법은 지역 및 공동체 기반의 마을기업을 육성·지원하여 지역일자리 및 소득을 창출함으로써 주민의 삶의 질 향상 및 지역문제의 자발적 해결에 이바지함을 목적으로 함(안 제 1 조)

- 나. “마을기업”이란, 마을주민 또는 마을주민으로 구성된 단체가 주도하여 지역문제 해결, 생활환경 개선, 일자리·소득 창출 등을 목적으로 해당 지역 의 인력, 향토, 문화, 자연자원 등 유·무형의 인적·물적 지역자원을 활용한 수익사업을 수행하는 마을단위의 사업체로서 제 10 조에 의하여 지정받은 기 업을 말함(안 제2조제1호)

- 다. 국가와 지방자치단체는 마을기업 육성 및 지속가능한 경쟁력 확보를 위 하여 종합계획 수립 및 지원시책을 추진하도록 함(안 제 3 조) 
〈표 3-3〉 마을기업육성지원법안 구조

\begin{tabular}{|c|c|c|c|}
\hline 구분 & 조항 & 20대 국회 법률제안안 & 21대 국회 법률제안안 \\
\hline \multirow{5}{*}{$\begin{array}{l}\text { 제1장 } \\
\text { 총칙 }\end{array}$} & 제1조 & 목적 & 좌동 \\
\hline & 제2조 & 정의 & 좌동 \\
\hline & 제3조 & 국가 및 지방자치단체의 책무 & 좌동 \\
\hline & 제4조 & 마을기업의 역할과 의무 & 좌동 \\
\hline & 제5조 & 다른 법률과의 관계 & 좌동 \\
\hline \multirow{5}{*}{$\begin{array}{c}\text { 제2장 } \\
\text { 마을기업 육성 } \\
\text { 추진체계 }\end{array}$} & 제6조 & $\begin{array}{l}\text { 마을기업 육성·지원에 관한 종합계획 } \\
\text { 의 수립 }\end{array}$ & 좌동 \\
\hline & 제7조 & 시·도별 지원계획 & 좌동 \\
\hline & 제8조 & 실태조사 & 좌동 \\
\hline & 제9조 & 마을기업육성위원회 & 좌동 \\
\hline & 제10조 & 시·도별 마을기업육성위원회 & 좌동 \\
\hline \multirow{4}{*}{$\begin{array}{c}\text { 제3장 } \\
\text { 마을기업의 지정 } \\
\text { 및 육성 }\end{array}$} & 제11조 & 마을기업의 지정 등 & 좌동 \\
\hline & 제12조 & 마을기업에 대한 지원 & 좌동 \\
\hline & 제13조 & 조세감면 및 사회보험료의 지원 & 좌동 \\
\hline & 제14조 & 마을기업의 지정취소 & 좌동 \\
\hline \multirow{5}{*}{$\begin{array}{c}\text { 제4장 } \\
\text { 마을기업 육성 } \\
\text { 기반조성 }\end{array}$} & 제15조 & 마을기업의 사업 & 좌동 \\
\hline & 제16조 & 마을기업진흥원 & $\begin{array}{c}\text { 해당 항목 삭제 후 } \\
\text { '마을기업지원기관'으로 변경 }\end{array}$ \\
\hline & 제17조 & 마을기업지원기관 & 포상 \\
\hline & 제18조 & 포상 & 감독 \\
\hline & 제19조 & 감독 & 권한·업무의 위임·위탁 \\
\hline \multirow{2}{*}{$\begin{array}{l}\text { 제5장 } \\
\text { 보칙 }\end{array}$} & 제20조 & 권한·업무의 위임·위탁 & 과태료 \\
\hline & 제21조 & 과태료 & - \\
\hline \multirow{4}{*}{ 부칙 } & 제1조 & 시행일 & 좌동 \\
\hline & 제2조 & 마을기업에 대한 경과조치 & 좌동 \\
\hline & 제3조 & 마을기업지원기관에 대한 경과조치 & 좌동 \\
\hline & 제4조 & 다른 법률의 개정 & 좌동 \\
\hline
\end{tabular}


- 라. 마을기업은 지역공동체와 지역사회 발전을 위한 사업을 추진하며, 사업 수익을 지역사회에 재투자하여 지속가능한 지역발전에 기여하여야 함(안 제4조제2항)

- 마. 행정안전부장관 및 시·도지사는 종합계획과 연도별 시행계획 및 시·도 별 지원계획이 효율적으로 수립.추진되기 위하여 마을기업의 활동과 사업 현황에 관한 실태조사를 할 수 있음(안 제8조제1항)

- 바. 행정안전부장관 및 시·도지사는 마을기업의 육성·지원에 관한 정책의 효율적인 추진을 위하여 마을기업육성위원회를 둘 수 있음(안 제9조부터 제10조까지)

- 사. 국가는 마을기업의 설립.운영에 필요한 사항에 대하여 예산의 범위에서 행정적·재정적 지원을 할 수 있음(안 제 12 조제 1 항) 


\section{제3절 시사점}

\section{가. 관광두레사업의 확장성과 실효성 제고를 위한 법적 근거 필요}

- 현행 관광진흥법 제 47 조7과 제 48 조에 근거하여 관광두레사업을 추진 중에 있 으나, 지방자치단체 등의 지원과 협력을 이끌어내기에는 법적 근거로서 불명 확하다는 한계가 제기됨

- 요컨대 지역주민 공동체의 주도적·협력적 참여에 기반하여 지속가능한 지역 관광을 도모하는 등 관광두레사업의 확장성과 실효성 제고를 위해서는 관광두 레사업의 명확한 법적 근거가 필요함

- 다만 관광진흥법은 관광 진흥을 위한 각종 시책을 포함하고 있으므로 관광두 레사업에 대한 별도의 법령을 제정하지 않고, 관광진흥법에 해당 사항을 추가 하는 방안도 검토할 수 있음

\section{나. 지자체 협력 지원 및 조례 제정 기반이 되는 법적 근거 필요}

- 지방자치단체 조례를 제정하여 관광두레사업에 대한 지원 근거를 마련하는 것 도 가능하나, 지방자치단체마다 여건이 상이하고 관광두레사업에 대한 관심도 와 협력 정도에 차이가 있음

- 전라남도는 관광산업을 지역특화산업으로서 육성하고자 '주민 주도 관광사 업 육성 및 지원 조례'를 제정함10)

- 안성시는 관광 진흥 조례를 전부 개정하여 주민 주도 관광 육성을 위한 법 적 기반을 마련하고자 노력 중임

10) 지방자치단체는 지방의 자치사무이거나 상위 법령에서 위임한 사항에 대해 조례를 제정할 수 있음. 전라남 도는 「지방자치법」제22조제9조제2항제 3 호파목에 명시되어 있는 ‘지역특화산업의 개발과 육성·지원’을 법 적 근거로 조례를 제정함 
- 상위 법령에 근거 조항을 마련함으로써 주민 주도 관광사업 추진에 대한 국가 관광 정책의 방향성을 제시하는 등 조례 제정 기반을 마련할 필요가 있음

\section{다. 별도 법률 제정 시, 사회적 분위기 조성 및 합의점 도출 필요}

- 별도 법률 제정 시, 입법 목적에 따른 내용을 종합적으로 포함할 수 있음

- 행정안전부가 2011년부터 본격 추진한 정책사업인 '마을기업육성사업'의 법적 근거로서 “마을기업육성지원법(안)”을 마련함

- 목적, 정의, 마을기업의 역할과 의무에서부터 마을기업 육성 추진체계, 마 을기업의 지정 및 육성, 마을기업 육성 기반 조성 등 마을기업 육성을 위한 사항을 포괄함

- 별도 법률 제정 필요성에 대한 국민적 공감대 형성과 관련 부처 간 합의점 도 출이 무엇보다 중요함

- 마을기업육성지원법(안)은 20 대 국회에 상정되었다가 20 대 국회 임기 만료 로 자동 폐기됨. 21 대 국회에 재상정되어 소관위원회에서 논의가 이루어지 고 있음

- 별도 법률(안) 통과를 위해서는 다른 법률 간의 관계를 고려해야 하며, 관련 부처 간 합의점을 도출하는 과정이 필요함 
관광두레 법제화 방안 연구

제4장 관광두레사업 법제화 방안 



\section{제1절 법제화 필요성}

\section{1. 관광두레 법제화 필요성}

\section{첫째, 관광두레사업의 제도적·안정적 추진}

- 관광두레사업은 지속가능한 관광을 위한 새로운 정책 모델로서, 지역주민들이 주도적·협력적으로 지역자원을 활용한 관광사업체를 지속 경영할 수 있도록 육성함. 2013년부터 문화체육관광부의 정책사업의 일환으로 추진되어 왔으며, 앞서 살펴 본 바와 같이 다양한 경제적·사회문화적·정책적 성과를 거두어 옴 - 1) 전국 곳곳에 주민들이 협력하여 직접 만들고 경영하는 다양한 주민사업 체 창업, 2) 주민 소득, 일자리 창출 등 지역 경제 활성화 거양, 3) 지역주민 을 비롯해 기획자 등 지역관광 주체 육성, 4) 지역주민의 인식 변화 및 공동 체성 강화, 5) 정책 패러다임 변화 선도 등과 같은 성과를 꼽을 수 있음

- 요컨대 관광두레사업이 관광사업의 다양성과 창의성을 확대하여 지역관광 활 성화와 관광산업 경쟁력 향상에 기여한다는 측면에서 제도적·안정적 추진이 필요함

\section{둘째, 관광두레사업 추진 시, 대내·외 협력과 지원 유도}

- 그동안 관광두레사업이 도출한 성과에도 불구하고, 관광두레사업 추진 과정에 서는 명확한 법적 근거 미비에 따라 대내·외 협력과 지원을 이끌어내는 데 어 려움을 겪어 옴

- 관광두레 $\mathrm{PD}$ 의 역할 및 관광두레사업의 필요성에 대한 지방자치단체별 이 해와 협력의 편차 발생, 이에 따라 관광두레사랑방을 비롯해 주민사업체 육 
성 지원 어려움, 관광두레사업 완료 이후 주민사업체에 대한 지원 및 관리 를 위한 중간지원조직의 운영 어려움 등이 제기됨

- 관광두레사업은 인력 양성, 역량 강화, 콘텐츠 개발 등 소프트웨어 및 휴먼웨 어 부문의 사업내용을 중점적으로 다루기 때문에, 주민 주도의 관광 사업을 육성하는 과정에서 하드웨어적 지원이 결합될 필요가 있음. 즉 지방자치단체 를 비롯해 다양한 기관과의 연계와 협력, 지원을 유도하기 위해 관광두레사업 의 방향성과 추진체계에 대한 법제화가 필요함

\section{셋째, 주민 주도 관광생태계 구축을 위한 법·제도적 기반 구축}

- 관광두레사업이 중앙 단위의 정책 사업에서 나아가 '주민 주도 관광 사업 육성 을 통한 지속가능한 지역관광 활성화'라는 소기의 목표를 달성하기 위해서는 3 년 혹은 최대5년 이라는 관광두레 사업기간 이후에도 지방자치단체가 관련 정책을 펼칠 수 있는 법·제도적 기반이 필요함

- 관광두레사업의 추진체계에 대한 법적 근거를 명확히 함으로써 중앙과 지 역의 역할을 배분하고, 관광두레 $\mathrm{PD}$, 중간지원기관 등에 대한 지원 근거를 마련할 필요가 있음

- 요컨대 '주민 주도 관광사업 육성을 통한 지속가능한 지역관광 활성화'라는 관광두레사업의 확장성과 실효성 제고를 위해 법령을 마련할 필요가 있음

\section{넷째, 관광두레 주민사업체에 법적 지위를 부여해 안정적 성장 기반 조성}

- 관광두레사업은 지역주민이 자발적·협력적으로 관광사업체를 경영할 수 있도 록 역량을 강화하는 데 주안점을 둠에 따라 주민사업체 창업 및 경영개선 시 필요한 하드웨어 등은 타 부처 사업을 연계하거나 지방자치단체의 지원을 필 요로 함. 하지만 관광두레 주민사업체에 대한 법적 지위가 부재하여, 이러한 연계와 협력을 이끌어 내는 데 한계가 있음

- 관광두레사업에서는 주민사업체 조직화, 사업계획서 수립, 역량 강화, 시제 품 개발 등 소프트웨어적 비용을 지원함 
- 관광두레 주민사업체를 관광기업으로서 안정적으로 성장시키기 위해 지방 자치단체의 물리적 공간 지원이 필요함

- 따라서 관광두레 주민사업체에 대한 법적 지위를 부여하여 안정적인 성장 기 반을 조성할 필요가 있음

\section{2. 관광두레 법제화 기대효과}

\section{첫째, 지역문제 해결과 일자리 창출 확대}

- 주민 주도 방식은 공공정책의 객체로서 여겨져 왔던 지역주민이 스스로 주체 가 되어 지역사회의 현안 해결에 자발적으로 참여하는 것을 의미함. 지역 관광 사업이 실질적인 지역경제 효과를 거두기 위해서는 관광사업의 간접적 파급효 과를 기대할 것이 아니라 주민 주도의 관광사업체 육성을 통해서 직접적인 소 득과 고용을 창출하는 것이 중요함(김성진·박주영, 2013)

- 관광두레사업의 안정적 추진을 통해 지역주민이 주도하여 지역의 문제를 관광 사업으로 해결하고, 이 과정에서 일자리가 만들어 지고 주민 소득이 향상될 수 있음. 최근 사회적 경제 영역의 활성화 필요성과 함께 일자리 창출이 주요 한 정책 화두로 대두되고 있는 만큼, 관광두레 법제화를 통해 이러한 정책적 요구에 보다 효과적으로 부응할 것으로 기대함

\section{둘째, 시설 조성보다 콘텐츠 운영으로 지역 관광개발 방향성 전환}

- 지방 분권화와 함께 상당수 관광개발 사업이 지방으로 이양되었거나 이양되고 있는 시점에, 중앙정부의 역할은 지방자치단체의 관광개발 사업에 대한 관리. 감독에서 관광개발의 바람직한 방향 제시로 전환되어야 함. 즉, 지방자치단체 가 단기적 혹은 가시적 성과 중심으로 건축물이나 장소형 매력물을 신규 조성 하는 데서 나아가 기존 자원의 다양한 연계와 활용, 유휴화 완화를 위한 소프 트웨어형 사업을 활발히 추진하도록 유도해야 함 
- 관광두레사업은 물리적 관광 매력물 개발보다는 지역 고유의 자원이나 매력물 을 어떻게 관광 사업화하고 지역 주민들이 경제적인 편익을 누릴 수 있도록 하느냐에 초점을 두고 있음. 따라서 관광두레 법제화는 이러한 정책적 방향성 을 나타낼 수 있으며, 지방자치단체의 정책 전환을 유도할 것으로 기대함

\section{셋째, 지역관광 차별성 및 매력성 향상, 주민 주도 지역관광 발전 도모}

- 그동안 관광개발사업 전반에서 주민의 참여가 적고, 지역 간 관광개발 콘텐츠 의 차별화가 부족하였음. 지역을 누구보다 더 잘 아는 지역주민이 지역자원을 활용하고 연계해 직접 관광 사업을 운영할 경우, 타 지역과는 다른 콘텐츠 매 력이 살아날 수 있음. 또한 이 과정에서 지역공동체 회복이 가능함

- 또한 관광 부문뿐만 아니라 농촌, 도시, 산림, 생태 등 다양한 부문에서 주민 주도 사업을 육성하고 있음. 즉, 주민 주도형 사업 육성은 시대적 흐름임. 관광 두레 법제화를 통해 지역사회 기반의 관광 콘텐츠가 안정적으로 개발됨으로써 지역 간 차별성과 매력성을 향상할 수 있으며, 주민 주도 지역관광의 발전을 꾀할 수 있음 


\section{제2절 법제화 방향 및 범위}

\section{1. 법제화 방향}

\section{1. 법제화 대안}

- 관광진흥법을 개정하는 안과 별도의 지원 법률을 신규 제정하는 안으로 접근 할 수 있음. 세부적으로는 관광진흥법에 관광두레사업에 대한 근거 조항을 신 설하는 안, 그리고 관광진흥법 시행령에 근거 조항을 신설하는 안이 있음. 마 지막으로 관광두레사업에 대한 별도의 지원 법률을 제정하는 안임

\section{가. 관광진흥법 내 조항 신설}

- 관광진흥법은 관광을 진흥하기 위한 법률적 기반을 제공하고 있으므로 관광진 흥법에 관광두레사업에 대한 근거 조항을 마련함

1) 관광진흥법 제 48 조의 12 부터 필요 조항 신설

- 신설 조문은 관광진흥법 “제4장 관광의 진흥과 홍보”의 맨 마지막에 두어 관 광두레사업을 국가의 관광 진흥 정책의 일환으로 인식하게 함

- 법률 전문가에 따르면, 제4장에는 관광의 진흥과 홍보에 관한 다수의 사항 들이 여러 차례 개정을 통하여 추가되었기 때문에 가지번호도 많고 앞뒤 조 문 사이의 관계가 매끄럽지 못 한 측면이 있음11). 신설 조문을 제4장의 조 문 중 유사성이 있는 것 다음에 배치하는 방법을 고려할 수 있지만, 유사성 이 높은 조항이 없으며 관광두레사업 관련 조문들을 적절한 곳에 집중하여

11) 가지번호란 제 42 조의2, 제 42 조의 3 등을 의미함 
배치하는 것이 이해 제고 측면에서 바람직함

- 향후 별도 법률로 독립시킬 경우를 대비하여 기존의 가지번호를 건드리지 않고 제4장의 마지막에 모아서 배치하는 것이 최선임

- 요컨대 관광진흥법 제 48 조의 12 부터 관광두레사업의 법적 근거로서 필요한 조 항을 신설함

2) 관광진흥법 제48조제4항제6호 신설

- 현재 관광두레사업은 관광진흥법 제 48 조제 4 항 "문화체육관광부장관과 지방 자치단체의 장은 관광객의 유치, 관광복지의 증진 및 관광 진흥을 위하여 대통 령령으로 정하는 바에 따라 다음 각 호의 사업을 추진할 수 있다"에 근거하여 관광 진흥을 위한 사업의 일환으로 추진되어 옴

- 하지만 제 3 호 관광상품의 개발에 관한 사업, 제 4 호 국민의 관광복지 증진에 관한 사업, 제5호 유휴자원을 활용한 관광자원화사업이 관광두레사업과 관 련성은 있지만, 직접적이고 명확한 근거 법령으로는 부족함

- 관광두레사업에 대한 명확한 법적 근거를 위해 제6호에 관광두레사업의 성격 이나 특성을 규정하는 표현으로 “주민 주도의 지역관광 활성화 사업” 혹은 “주 민공동체에 의한 관광자원화사업”을 신설함

\section{나. 관광진흥법 제47조의7을 근거로 동법 시행령에 조항 신설}

- 관광진흥법 제 47 조의 7 (관광산업 진흥 사업) 제 2 호와 제 5 호에 따르면, 문화체 육관광부장관은 대통령령으로 정하는 바에 따라 '관광 관련 창업 촉진 및 창업 자의 성장·발전 지원', '지역에 특화된 관광 상품 및 서비스 등의 발굴·육성'과 관련한 사업을 추진할 수 있음

- 관광진흥법 제 47 조의7을 근거로 시행령에 관광두레사업의 직접적 근거를 마 련함 


\section{다. 별도의 지원 법률 제정}

- 관광두레사업 추진을 위한 별도의 지원 법률을 제정함. 기존의 관광진흥법은 체 계상, 내용상 여러 내용이 혼재되어 있으므로, 별도의 지원 법률 제정을 통해 중 앙정부의 주민 주도 지역관광 활성화 사업 추진에 대한 의지를 분명히 할 수 있음

\section{2. 대안별 고려사항}

\section{가. 입법 과정의 편의성}

- 입법 과정의 편의성 측면에서 검토하면, 관광진흥법 시행령 내 조문 신설 $\rightarrow$ 관광진흥법 내 조문 신설 $\rightarrow$ 별도 지원 법률 제정 순으로 소요 시간과 행·재정 적 소모가 큼

- 시행령은 국무회의 의결로 개정이 가능해 입법 과정이 상대적으로 수월함. 다만 구체적인 내용을 시행령에 담기 위해서 위임근거를 법률에 명확히 마 련하라는 요구가 있을 수 있음

- 법제화 시점을 고려할 때, 단기적으로는 관광진흥법 시행령 내 조문 신설과 관광진흥법 내 조문 신설을 검토할 수 있으며, 중장기적으로는 별도 지원 법률 제정을 검토할 수 있음

- 한편 관광진흥법 내 조문 신설의 경우, 제 48 조의 12 부터 필요 조항을 신설 하는 안과 제 48 조제4항제6호를 신설하는 안 두 가지를 제시하였는데, 이 중 후자가 상대적으로 입법 과정이 수월할 수 있음

- 왜냐하면 관광진흥법 내 여러 조항을 신설하는 경우, 타 조항과의 관계 및 분량 상의 균형 등의 문제가 제기될 수 있기 때문임

- 새로운 법을 제정하는 경우 법안이 발의되어 국회 본회의를 통과하기까지 평 균 1년 6개월 2년 정도(의안 발의 법안)의 기간이 소요되고, 상당수 법안(정 부안 포함)은 통과되지 못한 채 폐기되고 있음

- 지난 20 대 국회에서 발의된 법안 2 만 4,141 건 중 1 만 5,125 건이 폐기되는 등 폐기율은 약 $62.6 \%$ 에 달하고 있음 
- 별도 지원 법률의 입법을 위해서는 다양한 토론회 개최 등을 통하여 해당 법 률안에 대한 사회적 관심을 제고하고, 법안의 필요성에 대한 범부처 간 합의점 을 도출하는 노력이 필요함

- 특히 유사 법률과의 차별성, 입법 비용을 상쇄할 정도의 입법 필요성 및 기 대효과 등이 확보되어야 함

\section{나. 입법 결과의 효과성}

- 입법 결과의 효과성 측면에서는 앞서 입법 과정의 편의성과 반대로 별도 지원 법률 제정 $\rightarrow$ 관광진흥법 내 조문 신설 $\rightarrow$ 관광진흥법 시행령 내 조문 신설 순으로 입법 효과를 기대할 수 있음

- 관광두레사업, 또는 주민 주도 및 주민공동체 기반의 지역관광 활성화사업을 부각시키고, 필요한 사항을 체계적으로 담아 입법 효과를 가장 높일 수 있는 안은 별도 지원 법률을 제정하는 것임

- 관광두레사업에 관한 체계적 지원 및 육성 방안 등이 제도화되고, 동 사업 의 추진 과정에서 발생한 문제를 효율적으로 해결하기 위한 체계가 마련될 수 있음

- 관광진흥법 시행령 내 조문을 신설하는 안은, 제 47 조의7(관광산업 진흥 사업) 제 2 호와 제 5 호에 근거함에 따라 '관광두레사업'을 관광산업 진흥 사업으로 범 주화하여 지속가능한 지역관광 활성화 모델로서의 성격이 약화될 가능성이 있 음. 더욱이 제 47 조의7은 문화체육관광부장관이 관광산업 진흥 사업을 할 수 있다고 명시하고 있기 때문에, 지방자치단체 등의 지원과 협력을 이끌어내고 자 하는 등 본 법제화의 취지를 살리기에 다소 부족함

- 한편 예산 투입의 우선순위를 고려할 경우, 법률에 규정한 사항에 비해 시행령 에 규정한 사항에 대하여 상대적으로 비중을 낮게 판단함. 또한 입법으로 인한 홍보 효과가 떨어지며, 법적 구속력도 법률에 규정한 사항에 비해 적음

- 관광진흥법 내 조항을 신설하는 것이 입법 결과의 효과성 측면에서는 위의 두 가지 대안의 절충안으로 볼 수 있음. 지원 대상, 전담조직, 전문인력, 국·공유 
재산 이용 등 관광두레사업의 안정적·체계적 추진을 위한 사항을 법률에 포함 함으로써 법제화 목적을 달성할 수 있음. 다만 관광진흥법의 조문 구성에 비추 어 관광두레사업과 관련해 너무 많은 조문을 할애할 경우, 관광진흥법 구성 체계 상 여타 조문들과의 관계에서 부조화와 불균형의 문제가 제기될 수 있음 - 따라서 관광진흥법 내 조항 신설 시, 필수적인 내용만 담고 하위 법령으로 위임하는 등의 방안을 고려할 필요가 있음

〈표 4-1〉법제화 대안별 고려사항

\begin{tabular}{|c|c|c|c|c|c|}
\hline \multicolumn{2}{|c|}{ 대안 } & $\begin{array}{l}\text { 법제화 } \\
\text { 시점 }\end{array}$ & $\begin{array}{l}\text { 입법 과정 } \\
\text { 의 편의성 }\end{array}$ & $\begin{array}{l}\text { 입법 결과 } \\
\text { 의 효과성 }\end{array}$ & 고려사항 \\
\hline \multirow{2}{*}{$\begin{array}{l}\text { 1. 관광진흥법 } \\
\text { 내 조항 신설 }\end{array}$} & $\begin{array}{l}1-1 . \\
\text { 제48조 12부터 } \\
\text { 필요 조항 신설 }\end{array}$ & \multirow{2}{*}{ 단기 } & 2 & 2 & $\begin{array}{l}\text { - 관광두레사업의 안정적·체계적 추진을 } \\
\text { 위한 내용을 담을 수 있지만, 조항의 내 } \\
\text { 용이 너무 많아질 경우 관광진흥법 내 } \\
\text { 타 조항과 불균형 문제 제기 가능 }\end{array}$ \\
\hline & $\begin{array}{l}1-2 . \\
\text { 제48조제4항 } \\
\text { 제6호 신설 }\end{array}$ & & 1.5 & 2 & $\begin{array}{l}\text { - 입법 과정의 편의성은 1-1안보다 조금 } \\
\text { 더 수월. 결과의 효과성은 1-1안과 유사 } \\
\text { - 다만 관광두레사업과 관련하여 시행령에 } \\
\text { 담을 수 있는 조항이 더 축약될 가능성 }\end{array}$ \\
\hline \multicolumn{2}{|c|}{$\begin{array}{l}\text { 2. 관광진흥법 제47조의7을 근거로 } \\
\text { 동법 시행령에 조항 신설 }\end{array}$} & 단기 & 1 & 3 & $\begin{array}{l}\text { - 시행령은 국무회의 의결로 개정이 } \\
\text { 가능해 입법 과정이 상대적으로 수월함 } \\
\text { - 법률에 규정한 사항에 비해 홍보효과 및 } \\
\text { 법적 구속력에 한계 } \\
\text { - 제47조의7은 문화체육관광부장관이 관 } \\
\text { 광산업 진흥 사업을 할 수 있다고 명시하 } \\
\text { 고 있기 때문에, 지방자치단체 등의 지원 } \\
\text { 과 협력을 이끌어내고자 하는 등 본 법제 } \\
\text { 화의 취지를 살리기에 다소 부족 } \\
\text { - 관광산업 진흥으로 범주화되어 신규 모 } \\
\text { 델로의 성격이 약화될 가능성 }\end{array}$ \\
\hline \multicolumn{2}{|c|}{ 3. 별도의 지원 법률 제정 } & $\begin{array}{l}\text { 중 } \\
\text { 장 } \\
\text { 기 }\end{array}$ & 3 & 1 & $\begin{array}{l}\text { - 관광두레사업의 안정적·체계적 추진을 } \\
\text { 위한 맞춤형 법률로서 입법 효과 높음 } \\
\text { - 신규 법률 제정은 평균 1년 } 6 \text { 개월에서 } \\
\text { 2년 정도의 시간이 소요 } \\
\text { - 사회적 관심과 부처 간 합의점 도출 } \\
\text { 필요 }\end{array}$ \\
\hline
\end{tabular}

주: 입법 과정의 편의성과 입법 결과의 효과성에서 제시한 숫자는 각 대안별 편의성과 효과성 측면의 순위임 


\section{2. 법제화 범위 및 내용}

\section{1. 법제화 범위 설정}

\section{가. 정책사업명 법률 명시 여부}

- "관광두레사업" 이라는 정책사업 명칭을 법률에 명시하는 것에 대하여 이해관 계자와 전문가들 사이에 여러 이견이 존재함. 법령에 순 우리말 용어를 담는 것 은 바람직하며, 관광두레사업이 지향하는 바를 명확하게 하도록 해당 용어를 사 용하는 것이 좋겠다는 의견이 있음

- 정책사업 명칭을 법제화하는 부분이 부담스럽다면, “관광두레사업” 대신 “관광두레”라고 표현해 생태관광이나 농촌관광이라는 용어처럼 관광두레를 주민들이 주도적·협력적으로 운영하는 관광 형태를 지칭하는 단어로 일반 명사화 하여 사용하는 것을 제안함

- 반면 정책사업명은 고유명사로서 법률에서 사용하지 않는 것이 통상적이며, 일반명사 또는 해당 정책이나 사업을 조문에서 풀어서 쓰는 게 일반적인 입법 기술이라는 의견이 있음. 또한 관광진흥법 일부개정을 고려할 경우, 관광부문 의 타 정책사업과 달리 관광두레사업만 법제화 하는 부분에 대해 부정적이라 는 의견이 있음

- 이상의 의견을 고려하여, 본 연구에서는 별도 법률 제정의 경우 예시로서 "관 광두레 진흥을 위한 지원 법률”, “주민공동체 기반의 관광 사업 육성을 위한 지원 법률"을 제안함. 관광진흥법과 동법 시행령 개정의 경우, “주민 주도 지 역관광 활성화 사업”, “주민공동체에 의한 관광자원화 사업”을 제안함

- 관광진흥법 제 2 조제 1 호와 제 2 호에 각각 “관광사업”과 “관광사업자”에 대한 정의를 별도로 두고 있기 때문에 관광두레사업을 대신해 "주민 주도 관광사 업”라는 포괄적인 표현을 쓰는 것이 해석상 혼란을 줄 수 있다는 의견이 있음 


\section{나. 별도의 법률 제정 시 포함할 사항}

- 제 2 장과 제 3 장의 분석결과를 토대로 관광두레사업의 안정적·제도적 성장과 발전, 체계적인 주민사업체의 육성·지원 관점에서 별도의 지원 법률(가칭, 관 광두레 진흥을 위한 지원 법률(안), 주민공동체 기반의 관광사업 육성을 위한 지원 법률(안))을 제정할 경우 포함할 사항은 다음과 같음

- 별도 지원 법률(안) 구성은 통상적인 진흥법의 장·절 체계 및 조문 구성을 따 름. 제3장에서 살펴 본 마을기업육성지원법(안)과 같이, 진흥법은 일반적으로 총칙, 추진체계, 사업의 내용, 기반 조성, 보칙으로 이루어짐

〈표 4-2〉별도 법률 제정 시 장·절 체계(안)

\begin{tabular}{|c|c|c|}
\hline 구분 & 조항 & 조문 \\
\hline \multirow{3}{*}{$\begin{array}{l}\text { 제1장 } \\
\text { 총칙 }\end{array}$} & 제1조 & 목적 \\
\hline & 제2조 & 정의 \\
\hline & 제3조 & 국가 및 지방자치단체의 책무 \\
\hline \multirow{4}{*}{$\begin{array}{c}\text { 제2장 } \\
\text { 관광두레 추진체계 }\end{array}$} & 제4조 & 관광두레사업 기본계획 등의 수립 \\
\hline & 제5조 & 실태조사 \\
\hline & 제6조 & 전담조직 \\
\hline & 제7조 & 주민사업체 협의체의 구성 \\
\hline \multirow{5}{*}{$\begin{array}{c}\text { 제3장 } \\
\text { 관광두레 지원 및 육성 }\end{array}$} & 제8조 & 관광두레사업의 범위 등 \\
\hline & 제9조 & 사업 대상지역 선정 및 평가 등 \\
\hline & 제10조 & 지방자치단체의 사업 \\
\hline & 제11조 & 주민사업체의 등록 \\
\hline & 제12조 & 재정 지원 \\
\hline \multirow{3}{*}{$\begin{array}{c}\text { 제4장 } \\
\text { 관광두레 기반 조성 }\end{array}$} & 제13조 & 관광두레사업 관련 교육·홍보 및 정보의 제공 \\
\hline & 제14조 & 국·공유재산의 대부 등 \\
\hline & 제15조 & 관광두레 육성·지원을 위한 전문인력 양성 \\
\hline 제5장 보칙 & 제16조 & 권한·업무의 위임·위탁 \\
\hline
\end{tabular}

- 제 1 장 총칙, 제 2 장 관광두레 추진체계, 제 3 장 관광두레 지원 및 육성, 제 4 장 관광두레 기반 조성, 제5장 보칙으로 구성함

- 제 1 장 총칙에서는 정의 조문이 가장 의미 있는 조문임. 다만 정의 조항에서 모든 개념에 대한 정의를 담기 보다는 관련 사항을 정한 본칙 조문을 통해 개념이 유추되도록 하는 방법이 가능함 
- 제 2 장과 제 3 장에 담는 관광두레 추진체계와 관광두레 지원 및 육성 방식이 가장 핵심적인 내용임. 추진체계는 관광두레사업을 체계적이고 조직적으로 수행할 수 있는 시스템에 대한 내용이며, 지원 및 육성은 관광두레사업의 구체적인 추진 방식에 대한 내용임

- 제 2 장 관광두레 추진체계에는 기본계획 등의 수립, 실태조사, 사업 추진 전 담조직, 주민사업체 협의체 구성을 담음

- 제3장 관광두레 지원 및 육성에는 관광두레사업의 범위, 사업 대상지역 선 정 및 평가, 지방자치단체의 사업, 주민사업체의 등록, 재정지원을 담음

- 제4장 관광두레 기반 조성에는 교육·홍보 및 정보의 제공, 국·공유재산의 대부, 전문인력 양성을 담음

- 제5장 보칙은 권한·업무의 위임·위탁을 포함함

- 제2장 추진체계와 유사하지만 약간 다른 성격을 가진 수단들이 제4장 기반 조성으로 구분해 입법되기도 함. 추진체계와 기반조성을 구분하여 입법할 만 큼 분량이 되지 않는다면 추진체계에서 함께 규정할 수 있음

\section{다. 관광진흥법 및 동법 시행령 일부 개정 시 반영사항}

- 관광진흥법에 새로운 법제화 필요성을 반영해 일부개정을 추진할 경우에는 기 존의 조문 체계와 조화를 이루어야 함

- 앞서 별도 법률 제정 시 고려한 조문 가운데 관광진흥법에 담기 어려운 조항 을 검토하고, 관광두레사업의 고유 특성 및 추진 방식, 기존 사업 추진과정에 서의 한계 해소 등을 고려함

- 별도 법률 상, 총칙에 해당하는 목적, 정의, 국가 및 지방자치단체의 책무 조 항은 관광진흥법 내 조항 신설 시 포함하기 어려움

- 관광진흥법의 목적은 "관광 여건을 조성하고 관광자원을 개발하며 관광사 업을 육성하여 관광 진흥에 이바지하는 것을 목적으로 한다"고 전체를 포괄 해 간단히 규정하고 있기 때문에, 관광진흥법의 목적 조항에 관광두레 지원 의 목적을 반영하기 어려움 
법률의 정의 규정은 법률 전반에서 두루 사용되는 개념을 정의하는 것이 일반 적이며, 일부 조문에서만 사용되는 용어는 해당 조문에서 괄호를 사용하여 정의하는 것이 일반적임

국가 및 지방자치단체의 책무 조항은 관광진흥법에 없는 조문으로서 총칙에 반영하기 어려움. 국가 및 지방자치단체의 역할에 대한 내용은 관광두레 지 원 및 육성 관련 조문에 포함하도록 함

- 관광두레사업과 관련한 기본계획 수립과 실태조사 등은 관광두레사업의 안정 적·체계적 추진을 위해 필요한 내용임. 다만 계획 수립은 행·재정적 소요를 동반하므로 제도화 필요성에 대한 검토가 필요함. 또한 관광두레 법제화 필요 성을 고려할 때, 필수불가결한 조문으로는 보기 어려움

〈표 4-3〉 관광진흥법 일부 개정 시 반영사항

\begin{tabular}{|c|c|c|c|c|}
\hline 구분 & 조항 & 별도 법률 제정 시 필요 조문 & & 관광진흥법 일부 개정 시 반영사항 \\
\hline \multirow{3}{*}{$\begin{array}{l}\text { 제1장 } \\
\text { 총칙 }\end{array}$} & 제1조 & 목적 & $x$ & $\begin{array}{l}\text { 관광진흥법 목적 조항에 반영이 어려우 } \\
\text { 므로 제외 }\end{array}$ \\
\hline & 제2조 & 정의 & $x$ & $\begin{array}{l}\text { 신설 조문에서 약칭으로 해결하는 방안 } \\
\text { 고려 }\end{array}$ \\
\hline & 제3조 & 국가 및 지방자치단체의 책무 & $x$ & $\begin{array}{l}\text { 관광진흥법에 없는 조문이므로 제외하되, } \\
\text { 국가 및 지방자치단체의 역할에 대한 내 } \\
\text { 용을 관광두레 지원 및 육성 부분에 포함 }\end{array}$ \\
\hline \multirow{4}{*}{$\begin{array}{l}\text { 제2장 } \\
\text { 관광두레 } \\
\text { 추진체계 }\end{array}$} & 제4조 & 관광두레사업 기본계획 등의 수립 & $\triangle$ & $\begin{array}{l}\text { 관련 기본계획 수립 제도화 필요성 검토 } \\
\text { 필요 }\end{array}$ \\
\hline & 제5조 & 실태조사 & $\triangle$ & 기본계획 반영 시 함께 반영 \\
\hline & 제6조 & 전담조직 & 0 & 핵심 조문, 별도 조문으로 신설 \\
\hline & 제7조 & 주민사업체 협의체의 구성 & $\triangle$ & $\begin{array}{l}\text { 관광진흥법 상의 지역관광협의회와 상이 } \\
\text { 하므로 반영 고려 }\end{array}$ \\
\hline \multirow{5}{*}{$\begin{array}{c}\text { 제3장 } \\
\text { 관광두레 } \\
\text { 지원 및 육성 }\end{array}$} & 제8조 & 관광두레사업의 범위 등 & 0 & 핵심 조문, 별도 조문으로 신설 \\
\hline & 제9조 & 사업 대상지역 선정 및 평가 등 & 0 & 핵심 조문, 별도 조문으로 신설 \\
\hline & 제10조 & 지방자치단체의 사업 & $\bigcirc$ & 핵심 조문, 별도 조문으로 신설 \\
\hline & 제11조 & 주민사업체의 등록 및 취소 & O & 핵심 조문, 별도 조문으로 신설 \\
\hline & 제12조 & 재정 지원 & 0 & 관광진흥법 보칙 제76조에 추가 \\
\hline \multirow{3}{*}{$\begin{array}{l}\text { 제4장 } \\
\text { 관광두레 } \\
\text { 기반 조성 }\end{array}$} & 제13조 & $\begin{array}{l}\text { 관광두레 관련 교육·홍보 및 정보 } \\
\text { 의 제공 }\end{array}$ & O & 전담조직의 역할에 포함하여 반영 \\
\hline & 제14조 & 국·공유재산의 대부 등 & 0 & 관광진흥법 제76조제3항 보완 \\
\hline & 제15조 & $\begin{array}{l}\text { 관광두레 육성·지원을 위한 전문 } \\
\text { 인력 양성 }\end{array}$ & ○ & 핵심 조문, 별도 조문으로 신설 \\
\hline 제5장 보칙 & 제16조 & 권한·업무의 위임·위탁 & $x$ & 관광진흥법 제80조 활용 \\
\hline
\end{tabular}


- 관광두레사업 전담조직(PD 포함), 관광두레사업의 범위, 지방자치단체의 사 업, 사업 대상지역 선정 및 평가 등, 주민사업체 등록 및 취소, 전문인력의 양 성은 앞서 분석한 관광두레 법제화 필요성에 근거한 내용으로서 핵심 조문으 로 반영함

\section{2. 각 조문별 내용 및 입법 취지12)}

\section{가. 제 1 장 총칙}

1) 제 1 조 목적

- 법률 제정을 통해 달성하고자 하는 목표를 명확하게 제시함. 국가 또는 지방자 치단체가 주민들이 주도적·협력적으로 지역 고유 자원을 연계·활용하여 관광 사업을 창업 및 경영개선 하는 데 필요한 지원을 하도록 함

- 관광진흥법 일부개정 시에는 반영하기 어려움

- (목적) 이 법은 국가 또는 지방자치단체가 주민들이 주도적·협력적으로 지역 고유 자원을 연계·활용 하여 관광 사업을 창업 및 경영개선 하는 데 필요한 사항을 정함으로써 지역관광 활성화와 주민들의 경제적 이익 보장, 공동체 의식 향상 등 지속가능한 관광 발전을 실현하는 데 목적이 있다.

2) 제2조 정의

- 조문에 쓰인 용어에 대한 개념 정의가 필요한 것은 '관광두레사업', '주민사업 체'임

- 관광진흥법 일부개정 시에는 별도 정의 조항을 넣지 않고, 관련 용어를 사용 한 조문에 설명을 적어 약칭을 사용하는 방식으로 규정하는 것이 일반적임

- '관광두레'는 주민의 자발적 참여와 지역자원의 연계·활용을 통한 새로운 방 식의 지역관광발전 모델을 의미하며, 관광두레사업은 이러한 지역관광발전 모 델을 조성하기 위한 사업을 의미함. 관광두레사업의 범위를 통해 사업 내용을 명확히 할 수 있음

12) 별도 법률을 제정하는 경우에 준하여, 조문별 내용과 입법 취지를 정리함. 관광진흥법 및 동법 시행령 개정 시, 필요 조문 내용을 구성하는 데 이를 참고할 수 있도록 함 
- 주민사업체는 1) 특정한 지역 주민들의 주체적·자발적·협력적 참여를 바탕으 로 하며 2) 지역 내의 문화유적지와 먹을거리, 탐방로, 축제, 숙박시설 등 기존 의 다양한 자원을 연계·활용함을 요소로 하고 3) 지역특화 브랜드와 관광 사 업을 창출하는 것을 목적으로 하며 4) 해당 주민들이 창업하고 그 운영을 주도 하는 지역관광 공동체라는 특성을 갖춘 것을 말함

- (정의) (1) “관광두레사업” 이란 주민의 자발적 참여와 지역자원의 연계·활용을 통한 새로운 방식의 지역관광발전 모델을 조성하기 위하여 문화체육관광부장관 또는 지방자치단체의 장이 실시하는 제9 조제 1 항 각 호의 사업을 말한다.

(2) “주민사업체”란 특정한 지역 주민들의 주체적·자발적·협력적 참여를 바탕으로 문화유적지와 먹을 거리, 탐방로, 축제, 숙박시설 등 지역 고유의 자원을 연계·활용함으로써 지역특화 브랜드와 관광 사업을 창출하기 위하여 해당 주민들이 창업하고 그 운영을 주도하는 지역관광 공동체를 말한다.

\section{3) 제3조 국가 및 지방자치단체의 책무}

- 법률의 목적 실현을 위해 국가 및 지방자치단체가 해야 할 책무를 명확하게 하고자 관련 내용을 포함함

- 관광진흥법 일부개정 시에는 반영하기 어려움

- (국가 및 지방자치단체의 책무) (1) 국가는 관광두레사업의 지속적·체계적 추진을 위하여 필요한 행. 재정적 지원을 실시할 책무를 진다.

(2) 지방자치단체는 관광두레사업이 지역관광의 활성화를 촉진하고 주민 주도 관광생태계를 조성할 수 있도록 해당 지역 내 주민사업체에 대하여 필요한 행·재정적 지원을 할 책무를 진다.

\section{나. 제2장 관광두레 추진체계}

\section{1) 제4조 관광두레 기본계획 등의 수립}

- 관광두레사업 추진에 대한 기본계획과 시행계획 수립은 사업을 장기적 관점에 서 안정적·체계적으로 수행하도록 하는 요소이며, 추진체계의 중요 부분임. 기본계획의 법적 성격은 행정계획이며, 담당자의 교체 등에도 불구하고 해당 계획기간 동안에는 행정주체에 대한 내재적 구속력을 발생하기 때문에 사업의 안정적·체계적 추진이 가능함

- 관광진흥법 일부개정 시에는 제도화 필요성에 대한 검토 후 반영할 필요가 있음 
- 특히 국가가 수립한 기본계획은 지방자치단체로 하여금 시행계획의 수립과 집 행이라는 구체적인 의무를 발생시킴

- 기본계획이 5년이라는 비교적 장기간을 주기로 하는 반면, 시행계획은 연도 별 계획으로서 계획의 내용도 보다 구체성을 땀

- 관련 예산을 확보하는 과정에서도 행정계획은 관련 기관간의 협의를 거쳐 수 립되었다는 점에서 유용성을 발휘할 수 있음

- (관광두레 기본계획 등의 수립) (1) 문화체육관광부장관은 제1조의 목적을 달성하기 위하여 제9조제1 항 각 호의 사항이 포함된 관광두레사업 기본계획(이하, "기본계획" 이라 한다)을 필요시 관계 중앙행 정기관의 장과 협의하고 지방자치단체의 의견을 들어 5 년 마다 수립하고 이를 지방자치단체의 장에 게 송부하여야 한다.

(2) 지방자치단체의 장은 기본계획의 범위에서 해당 지역에서의 관광두레사업 추진에 필요한 사항에 대하여 해마다 관광두레사업 시행계획(이하, "시행계획"이라 한다)을 수립하고 이를 문화체육관광부 장관에게 제출하여야 한다.

(3) 기본계획 및 시행계획의 수립절차 등에 필요한 사항은 대통령령으로 정한다.

\section{2) 제5조 실태조사}

- 실태조사는 정책을 추진하는 데 있어 기초가 되는 정보와 자료를 얻기 위한 수단임. 각 법률에서 기본계획의 수립 등과 관련하여 실태조사를 법에 명시하 는 이유는 자료 내지 정보에 근거한 계획의 수립을 보장한다는 의미도 있지만, 현실적으로 관련 사업 예산을 확보하는데 근거 조문이 되기 때문임

- 기본계획 수립과 연동하는 조문으로서, 관광진흥법 일부개정 시 기본계획 수립에 대한 제도화 필요성 검토 후 반영할 필요가 있음

- 실태조사의 범위와 조사 시기, 방법 등은 하위법령에서 정하도록 위임함

- (실태조사) (1) 문화체육관광부장관은 기본계획과 시행계획을 효율적으로 수립·추진하기 위하여 관광 두레사업에 대한 실태조사를 할 수 있다.

(2) 실태조사의 범위와 방법 등 필요한 사항은 대통령령으로 정한다. 


\section{3) 제6조 전담조직(중간지원기관)}

- 관광두레사업에 대한 지원 등 추진주체는 재원이 되는 관광진흥개발기금의 관 리주체인 문화체육관광부이지만13), 단계별·맞춤형 지원 과정을 중요시하는 관광두레사업의 특성 상 전문인력(관광두레 $\mathrm{PD}$ )의 활동 지원과 관리, 주민사 업체 발굴 및 육성, 사업화계획의 수립 지원, 주민사업체의 창업과 경영개선 및 파일럿 사업 지원, 사업에 대한 모니터링, 평가 등 다양한 활동이 수반됨. 이는 행정관청의 역량만으로는 충분하지 않기 때문에 실제 업무는 민간기관에 위탁하여 실시할 필요가 있음

- 관광진흥법 일부 개정 시 반영이 필요한 핵심 조문임

- 전담조직 지정 및 운영을 위해서는 법령의 근거가 필요함

- 지방자치단체가 전담조직을 운영하여 관광두레사업과 관련한 협력 체계를 마련하거나, 자체적인 주민 주도 사업을 추진하도록 할 수 있음

- (전담조직) (1) 문화체육관광부장관 또는 지방자치단체의 장은 관광두레사업 지원을 위하여 필요한 경우에는 대통령령 또는 해당 지방자치단체의 조례로 정하는 기관 중에서 그 지원을 전담하는 조직을 지정할 수 있으며, 그 조직의 운영 등에 필요한 경비를 지원할 수 있다.

- (2) 제1항의 전담조직에 대한 필요한 사항은 대통령령으로 정한다.

\section{4) 제7조 주민사업체 협의체의 구성}

- 관광두레사업을 통해 육성한 각각의 주민사업체만으로는 지역관광 활성화 및 지속가능한 관광 발전과 같은 관광두레사업이 지향하는 바를 달성하기 어려 움. 주민사업체 간 협의체를 구성해 서로를 연계하는 관광 상품과 서비스를 마련할 경우 관광객을 유인할 수 있는 경쟁력이 강화될 수 있음. 현재 관광두 레사업 대상지역별로 관광두레협의회를 구성하고 있으나 지속적으로 성장·발 전할 제도적 기반이 부족한 상황임

- 관광진흥법 일부 개정 시 반영을 고려할 수 있음

- 주민사업체 협의체의 경우 지역관광추진조직(Destination Management/ Marketing Organization: $\mathrm{DMO}$ )로 발전하거나 주민 주도 관광생태계 조성

13) 관광진흥개발기금법 제3조(기금의 관리) (1) 기금은 문화체육관광부장관이 관리한다. 
을 위한 지역 전담조직으로 활동할 수도 있음

- (주민사업체 협의체의 구성) (1) 주민사업체는 관광두레사업의 효율적 추진과 상호 부조 등을 위하여 협의체를 구성할 수 있다.

(2) 제1항의 협의체의 구성, 운영 및 지원에 관하여 필요한 사항은 대통령령으로 정한다.

\section{다. 제3장 관광두레 지원 및 육성}

1) 제8조 관광두레사업의 범위 등

- 관광두레사업을 추진할 법적 근거 조항으로 볼 수 있음. 국가 또는 지방자치단 체가 수행하는 사무의 신설 및 배분에 관한 문제와 연결됨

- 법령에서 재정지원을 규정하기 위해서는 먼저 지원 대상이 되는 사무가 신 설되어야 하며, 이러한 사무는 국가와 지방자치단체 간의 배분이 필요함

- 관광진흥법 일부 개정 시 반영이 필요한 핵심 조문임

- 현재 관광두레사업은 문화체육관광부가 관광진흥개발기금을 토대로 사업을 추진하며, 기초지방자치단체가 간접적 지원을 하고 있음. 하지만 관광두레사 업을 통해 육성하는 주민사업체는 지역관광 활성화의 주체로 성장하게 되므 로, 기초지방자치단체의 지원과 관리가 중요함

- 최초 중앙정부가 최장 5년까지 지원을 하는 기간에도 기초지방자치단체가 지원할 수 있는 체계가 갖춰줘야 하며, 중앙정부의 지원이 종료된 후에도 해 당 주민사업체에 대하여 지방자치단체의 행·재정적 지원이 이루어질 필요가 있음. 이 경우 사무배분의 원칙(기초지방자치단체 우선의 원칙)에 비추어 보 거나 현재 기초지방자치단체 단위로 대상 지역이 선정되는 것을 고려할 때, 기초자치단체가 주도적인 지원 주체로서 역할을 담당하는 것이 타당함

- 그러나 이러한 사무의 핵심은 재정지원이고 기초지방자치단체의 재정 구조 가 광역지방자치단체와 긴밀하게 연동되므로 광역지방자치단체의 협력과 지원이 동반되어야 함. 광역지방자치단체는 지원 대상 사업체나 전담조직 등에 출연이나 보조를 통한 재정지원을 하는 방식으로 관여할 수 있음 
- (관광두레사업의 범위 등) (1) 문화체육관광부장관 또는 지방자치단체의 장은 지역관광의 활성화를 촉진하고 주민 주도 관광생태계를 조성할 수 있도록 각 호의 사항을 지원할 수 있다.

1. 주민사업체 발굴 및 육성 지원

2. 교육·홍보 및 정보의 제공

3. 시설 및 유휴공간 지원

4. 주민사업체 지원을 위한 전문인력 육성 및 활동비 지원

5. 지역자원 활용 콘텐츠 개발

6. 그 밖에 관광두레사업 지원·육성을 위하여 필요한 사항

(2) 문화체육관광부장관 또는 광역 및 기초지방자치단체의 장은 제 1 항의 지원을 함에 있어 상호 간의 역할 배분에 관하여는 대통령령으로 정한다.

\section{2) 제9조 사업 대상지역 선정 및 평가 등}

- 관광두레사업은 기초지방자치단체를 범위로 매년 공모를 통해 대상지역을 선 정하며, 기본 3년 간 지원하고 매년 연차별 평가 및 종합평가를 통해 최대 5년 간 중앙정부의 지원이 이루어짐

- 매년 각 지원 대상지역별, 연차별 사업 성과 평가에 따라 지속 추진 타당성이 낮으면 해당 지역에 대한 사업을 종료하고, 3 개년 사업 종료 후 종합평가를 진행하여 모범 사례 지역은 2년 간 추가로 지원 사업을 추진함

- (사업 대상지역 선정 및 평가 등) (1) 문화체육관광부장관은 제8조의 사업을 효율적으로 실시하기 위 하여 해마다 기초지방자치단체 중에서 사업실시 대상지역을 선정하여 기본 3년 동안 지원을 실시하 며, 지원에 따른 실적을 매년 평가하여 평가 결과에 따라 지원을 차등하거나 종료할 수 있다.

(2) 문화체육관광부장관은 제 1 항의 평가 결과를 반영하여 2 년의 범위에서 추가적으로 지원할 수 있다.

(3) 제 1 항에 따른 선정 및 평가 기준과 그 밖에 지원에 관하여 필요한 사항은 대통령령으로 정한다.

\section{3) 제10조 지방자치단체의 사업}

- 관광두레사업은 주민공동체를 발굴하여 지역 특화 관광사업체로 창업 및 경영 개선할 수 있도록 지원하는 데, 기본 3년의 지원 기간이 부족할 수 있음. 따라 서 공모를 통해 관광두레사업 대상지역으로 선정하기 이전부터 지역문제를 관 광사업으로 해결하려는 의지를 가진 공동체를 발굴하는 등의 사업을 지방자치 단체에서 추진하는 것이 보다 효과적일 수 있음

- 관광진흥법 일부 개정 시 반영이 필요한 핵심 조문임 
- 또한 기본 3 년, 최대 5 년의 지원 기간이 종료된 이후에, 관광두레사업을 통해 육성한 주민사업체에 대한 후속 지원 및 관리가 필요함. 아울러 지역의 실정에 맞는 주민 주도 관광사업을 계속하여 지원할 근거를 마련할 필요가 있음

- (지방자치단체의 사업) 지방자치단체의 장은 제 9 조제 1 항의 대상 지역으로 선정되기 전에 해당 지역 내에서 제 8 조제 1 항 각 호의 사업을 독자적으로 시행하거나 제 9 조제 2 항의 지원이 종료된 이후 필요 한 사항을 조례로 정하는 바에 따라 지원할 수 있다.

4) 제11조 주민사업체의 등록 및 취소

- 관광두레사업은 규제 성격이 아니라 진흥 성격의 사업이기 때문에 주민사업체 에 대해 특별한 부담이나 의무를 지워서는 안 됨. 하지만 국가 또는 지방자치 단체의 재정이 투입되는 경우에는 지원 대상이 되는 주민사업체를 관리할 필요 가 있으며, 지원 대상에 포함할 수 있도록 명확한 근거를 마련한 필요가 있음 - 관광진흥법 일부 개정 시 반영이 필요한 핵심 조문임

- 현재 관광두레사업을 통해 창업 및 경영개선을 완료한 주민사업체에게는 '관 광두레 현판' 설치를 지원하고 있으나, 외부적으로 관광두레 주민사업체임을 알리는 수단에 불과함

- 관광두레사업을 통해 창업 및 경영개선을 완료한 주민사업체의 법인격은 공동체 성격 및 사업 유형에 따라 협동조합, 영농조합법인, 주식회사 등 다 양함. 관광진흥법에서 규정하는 관광사업자인 경우도 있으나, 숙박업 및 일 반음식점업 등 관광진흥법 내 관광사업 범주에 포함하지 않는 경우도 있음

- 관광두레사업은 공동의 목표를 가진 주민공동체(임의조직)도 지원 대상으로 하고 있으나, 단계별·맞춤형 지원을 체계적으로 시행하기 위해 별도의 등록 절차를 거치도록 함

- 조직화 단계, 사업화계획 수립 등 중앙정부의 소프트웨어 지원으로 충분한 창업 준비 단계와 하드웨어 시설 지원 등이 필요한 창업 단계로 주민사업체 의 위상을 구분함

- 즉 지방자치단체의 재정이나 시설 지원 등의 대상이 되기 위해서는 별도의 등록 절차를 거치도록 함 
- 등록은 의무가 아니라 지원을 받기 위한 전제조건으로 운영하고 과태료 등 은 부과하지 않음 14$)$

- 또한 관광두레사업이 지향하는 주민공동체 기반의 주도적·협력적 사업 추진 과 지역 고유자원의 활용을 통한 지역 내 관광 소비의 순환 등을 지속적으로 실현하기 위하여, 이러한 취지에 부합하지 않는 주민사업체의 등록 취소 내용 을 포함함

- 다만 현재는 이러한 체계를 갖추고 있지 않으므로, 주민사업체 등록 제도화에 대해서는 필요성과 효과성 측면에서 추가적인 논의가 필요함

- (주민사업체의 등록 및 취소) (1) 이 법에 따른 지원을 받고자 하는 주민사업체는 문화체육관광부 장관 이 정하는 바에 따라 기초지방자치단체의 장에게 등록하여야 한다.

(2) 기초지방자치단체의 장은 주민사업체가 다음 각 호의 어느 하나에 해당하면 등록을 취소하거나 문화체육관광부 장관이 정하는 바에 따라 일정 기간 이 법에 따른 지원을 중단할 수 있다. 다만 제1 호에 해당하면 그 등록을 취소하여야 한다.

1. 거짓이나 그 밖에 부정한 방법으로 주민사업체 선정 및 등록을 한 때

2. 동일한 내용에 대하여 타 사업비와 중복하여 지원받았을 때

3. 주민사업체의 구성이나 운영 형태 등이 제1항에서 정하는 바에 부합하지 않을 때

4. 주민사업체와 관련하여 관광두레사업 등에 직접·간접적 영향을 미치는 민사 또는 형사 사건이 발생하였을 때

(3) 기초자치단체의 장은 주민사업체 등록 및 운영현황을 매년 12 월 말까지 문화체육관광부장관과 관할 광역자치단체의 장에게 통지하여야 한다.

\section{5) 제12조 재정 지원}

- 관광두레사업은 지속가능한 관광 발전과 주민 주도 관광생태계 조성을 위한 진흥 정책으로서, 안정적인 사업 추진을 위해서는 재정의 확보가 중요함. 예산 은 법적 근거가 마련되어야 안정적으로 확보할 수 있음

- 관광진흥법 일부개정 시, 재정지원에 대해 다루고 있는 기존 관광진흥법 보 칙 제76조에 관광두레사업에 대한 내용을 추가하는 것을 고려할 수 있음

- 예산 지출의 법적 근거는 개별 법률에서는 예산을 지원할 수 있다는 점만 규 정하고, 「보조금 관리에 관한 법률」과 동 법 시행령을 정비하는 것이 일반적인

14) 이러한 입법 방식은 최초 박물관 및 미술관 진흥법에서 시도되었고 지금은 상당히 많은 법률에서 이용하 고 있음(박물관 및 미술관 진흥법 제16조제1항 등 참조) 
방법임. 또한 관광진흥개발기금 활용에 대한 근거는 우선적으로 관광진흥개발 기금법에서 정하는 것이 원칙임

- (재정 지원) (1) 국가는 지방자치단체가 관광두레사업을 실시하는 데 필요한 재원을 보조금으로 지원 할 수 있다.

(2) 국가는 관광진흥개발기금법에 따른 관광진흥개발기금의 재원으로 관광두레사업을 실시하는 데 필 요한 지원을 할 수 있다.

\section{라. 제4장 관광두레 기반 조성}

1) 제13조 관광두레 관련 교육·홍보 및 정보의 제공

- 관광두레사업은 지역주민의 자발적인 참여에 기초하고 있으며, 관광두레 주민 사업체가 지속가능하게 성장하기 위해서는 관광객들이 주민사업체에 대한 정보 를 충분히 인지하고 관련 상품과 서비스를 소비하여야 함. 따라서 지역주민과 일반 국민을 대상으로 관광두레사업에 대한 교육·홍보 및 정보 제공이 필요함 - 관광진흥법 일부개정 시, 전담조직의 역할 및 업무 범위에 대한 내용을 신 설하면서 해당 내용을 포함하는 것을 고려할 수 있음

- (관광두레 관련 교육·홍보 및 정보의 제공) 문화체육관광부장관 또는 지방자치단체의 장은 관광두레 사업의 시행과 주민사업체에 대한 지원을 위하여 대통령령으로 정하는 바에 따라 교육, 홍보를 실시 하거나 관련 정보를 제공할 수 있다.

\section{2) 제14조 국·공유재산의 대부 등}

- 관광두레 주민사업체나 전담조직, 주민사업체 협의체에 대해 국가나 지방자치 단체가 소유하는 행정재산이나 일반재산의 일부를 이용하게 할 필요가 있고 이 경우 대부 또는 사용수익허가를 받는 요건이나 방식15)에서 「국유재산법」

15) 국유재산법의 경우 제한사항 예시

제31조(사용허가의 방법) (1) 행정재산을 사용허가하려는 경우에는 그 뜻을 공고하여 일반경쟁에 부쳐야 한다. 다만, 사용허가의 목적·성질·규모 등을 고려하여 필요하다고 인정되면 대통령령으로 정하는 바에 따라 참가자의 자격을 제한하거나 참가자를 지명하여 경쟁에 부치거나 수의(隨意)의 방법으로 할 수 있다.

(2) 제1항에 따라 경쟁에 부치는 경우에는 총괄 청이 지정·고시하는 정보처리장치를 이용하여 입찰공 고·개찰·낙찰선언을 한다. 이 경우 중앙관서의 장은 필요하다고 인정하면 일간신문 등에 게재하는 방법 을 병행할 수 있으며, 같은 재산에 대하여 수 회의 입찰에 관한 사항을 일괄하여 공고할 수 있다. 
과 「공유재산 및 물품관리법」에서 까다롭게 규제하고 있는 사항에 대하여 특 례를 인정할 필요가 있음. 대부료나 사용료의 금액을 감면해 주는 것도 지원에 필수적인 사항임

- 관광진흥법 일부개정 시, 기존 관광진흥법 보칙 제76조제3항을 보완하는 것을 고려할 수 있음

- 그런데 국유재산법에 대한 특례의 설정은 「국유재산특례제한법」에서 동 법의 별표를 개정하여야만 효력을 갖도록 통제하고 있어16) 그러한 개정 작업도 병 행되어야 함

- (국·공유재산의 대부 등) 문화체육관광부장관 또는 지방자치단체의 장은 주민사업체 또는 제6조의 전담조직과 제8조의 주민사업체 협의체에 대하여 국유재산 또는 공유재산을 대통령령으로 정하는 바 에 따라 대부하거나 사용 수익하게 할 수 있으며 대부료나 사용료를 경감할 수 있다.

\section{3) 제 15 조 관광두레 육성·지원을 위한 전문인력 양성}

- 전문인력 양성 부분은 관광두레PD에 해당하는 내용임. 관광두레사업의 지역별 총괄책임자이자 기획자, 주민사업체 지원에 대해 중심적 매개 역할을 하는 관광두 레PD는 관광두레사업의 추진체계 상 주요 특징임. 다만 관광두레PD는 자격제도 나 일반화된 명칭이 아니기 때문에 법령에 그대로 반영하기에 어려움이 있음

(3) 행정재산의 사용허가에 관하여는 이 법에서 정한 것을 제외하고는 「국가를 당사자로 하는 계약에 관한 법률」의 규정을 준용한다.

제34조(사용료의 감면) (1) 중앙관서의 장은 다음 각 호의 어느 하나에 해당하면 대통령령으로 정하는 바 에 따라 그 사용료를 면제할 수 있다.

1. 행정재산으로 할 목적으로 기부를 받은 재산에 대하여 기부자나 그 상속인, 그 밖의 포괄승계인에게 사용허가하는 경우

1의2. 건물 등을 신축하여 기부채납을 하려는 자가 신축기간에 그 부지를 사용하는 경우

2. 행정재산을 직접 공용·공공용 또는 비영리 공익사업용으로 사용하려는 지방자치단체에 사용허가하 는 경우

3. 행정재산을 직접 비영리 공익사업용으로 사용하려는 대통령령으로 정하는 공공단체에 사용허가하는 경우

(2) 사용허가를 받은 행정재산을 천재지변이나 「재난 및 안전관리 기본법」 제 3 조제 1 호의 재난으로 사용 하지 못하게 되면 그 사용하지 못한 기간에 대한 사용료를 면제할 수 있다.

(3) 중앙관서의 장은 행정재산의 형태·규모·내용연수 등을 고려하여 활용성이 낮거나 보수가 필요한 재

산 등 대통령령으로 정하는 행정재산을 사용허가하는 경우에는 대통령령으로 정하는 바에 따라 사용료

를 감면할 수 있다.

16) 제4조(국유재산특례의 제한) (1) 국유재산특례는 별표에 규정된 법률에 따르지 아니하고는 정할 수 없다.

(2) 이 법 별표는 이 법 외의 다른 법률로 개정할 수 없다. 
- 관광진흥법 일부개정 시 반영이 필요한 핵심 조문임

- 법률에서 규정한 사항 외에 전문인력의 선정, 기능, 운영방식 등에 대해 하 위 법령 등에서 구체화하도록 하여 그 역할을 명확히 하고 공정한 선정 및 운영을 도모함. 청년관광두레 $\mathrm{PD}$ 의 선정 등도 하위 법령에 반영하여 운영함

- (관광두레 육성·지원을 위한 전문인력 양성) 문화체육관광부장관 또는 지방자치단체의 장은 관광두레 지원·육성을 위하여 대통령령으로 정하는 바에 따라 전문인력을 발굴·양성 및 평가하고 그 활동을 지원할 수 있다.

\section{4) 제16조 권한·업무의 위임·위탁}

- 전담조직 등을 설정 또는 지정하는 것과 관련하여 행정기관이 수행할 업무 중 일부는 이들 전담조직에 위탁하여 수행할 필요가 있음

- 관광진흥법 일부개정 시에는, 현행 관광진흥법 제 80 조제 3 항에 민간위탁의 위탁 및 수탁기관과 대상을 정하고 있으므로 대상 업무만 추가하면 됨

- (권한·업무의 위임·위탁) 문화체육관광부장관 또는 지방자치단체의 장은 제8조제 1 항 각호의 지원 업 무에 관한 권한의 전부 또는 일부를 대통령령으로 정하는 바에 따라 제6조의 전담조직에 위탁할 수 있다. 


\section{제3절 법제화 방안}

- 앞서 대안으로 제시한 관광진흥법 일부개정(안), 관광진흥법 시행령 일부개정 (안), 별도 지원 법률(안)을 예시 형태로 규정함

- 본 절에서 제시한 각 대안은 병렬적 위계를 가짐. 예를 들어 관광진흥법 시 행령 일부개정(안) 예시는 관광진흥법 일부개정이나 별도 지원 법률 제정 등을 대신해 단기적으로 추진할 수 있는 대안임

- 별도 지원 법률 제정이나 관광진흥법 일부개정 시 함께 다루어야 하는 대통 령령(시행령) 예시는 포함하지 않음

\section{1. 관광진흥법 내 조항 신설(안)}

\section{1-1. 관광진흥법 제48조 내 조항 신설(안)}

\section{가. 조문의 위치}

- 현행 관광진흥법 “제4장 관광의 진흥과 홍보”의 마지막에 위치하여 국가의 관 광진흥시책의 일환으로 “주민 주도 지역관광 활성화사업”을 명시함

- 앞서 검토한 바와 같이 "관광두레사업" 이라는 정책 브랜드 대신에 "주민 주도 지역관광 활성화사업”으로 규정함

- 제 48 조의 12 , 제 48 조의 13 , 제 48 조의 14 를 신설함 


\section{나. 주요 내용}

- 제 48 조의 12 는 관광두레사업의 추진 체계에 대한 내용을 포함함. 관광두레사업 선정 및 지원 기간, 사업내용과 범위, 지방자치단체의 역할 및 지원 등을 담음

- 사업 내용 및 범위에 관광두레 $\mathrm{PD}$ (전문인력)의 발굴, 육성, 평가 및 활동비 지원 등을 명시함

- 특히 관광두레사업 대상지역으로 선정된 기초지방자치단체가 관광두레사랑 방을 비롯해 원활한 협력과 지원을 유도할 수 있도록 근거를 마련함

- 지방자치단체 자체적으로 주민 주도 지역관광 활성화를 위한 사업을 추진 할 수 있는 근거를 마련함

- 제 48 조의 13 은 관광두레사업의 총괄지원 혹은 지방자치단체의 중간지원기관 과 관련하여 전담조직에 대한 법적 근거를 포함함. 전담조직의 역할과 관광두 레PD의 육성 및 활동 범위 등을 담음

- 제 48 조의 14 에는 주민사업체 지원 근거를 공고히 하고, 효율적 관리 등을 위 해 주민사업체 등록 및 취소에 관한 사항을 규정함

\section{다. 관광진흥법 일부개정(예시 안)}

\section{「관광진흥법 일부개정(예시 안)」}

관광진흥법의 일부를 다음과 같이 개정한다.

제4장에 제48조의12부터 제48조의14까지를 각각 다음과 같이 신설한다.

제48조의12(주민 주도 지역관광 활성화사업 지원 등) (1) 문화체육관광부장관 또는 지방자치단체의 장 은 주민의 자발적 참여와 지역자원의 연계·활용을 통한 새로운 방식의 지역관광발전 모델을 조성하기 위하여 다음 각 호의 사항을 지원하는 주민 주도 지역관광 활성화사업을 추진할 수 있다.

1. 주민사업체(특정한 지역 주민들의 주체적·자발적·협력적 참여를 바탕으로 문화유적지와 먹을거리, 탐방로, 축제, 숙박시설 등 지역 고유의 자원을 연계·활용함으로써 지역특화 브랜드와 관광 사업 을 창출하기 위하여 해당 주민들이 창업하고 그 운영을 주도하는 지역관광 공동체를 말한다. 이하 같다)의 발굴 및 육성 지원

2. 교육·홍보 및 정보의 제공

3. 시설 및 유휴공간 지원

4. 주민사업체 지원을 위한 전문인력 발굴, 육성, 평가 및 활동비 지원 
5. 지역자원 활용 콘텐츠 개발

6. 그 밖에 주민 주도 지역관광 활성화사업 지원·육성을 위하여 필요한 사항

(2) 문화체육관광부장관 또는 지방자치단체의 장은 제 1 항의 지원을 함에 있어 제 3 항과 제 4 항에서 정 한 사항을 고려하여 대통령령으로 정하는 바에 따라 상호 간의 역할을 배분한다.

(3) 문화체육관광부장관은 제 1 항의 사업을 효율적으로 실시하기 위하여 해마다 기초지방자치단체 중 에서 사업실시 대상지역을 선정하여 기본 3년 동안 지원을 실시하며, 지원에 따른 실적을 매년 평가 하여 평가 결과에 따라 지원을 차등하거나 종료할 수 있다.

(4) 문화체육관광부장관은 제 3 항의 평가 결과를 반영하여 2 년의 범위에서 추가적으로 지원할 수 있다.

(5) 제 3 항에 따른 선정 및 평가 기준과 그 밖에 지원에 관하여 필요한 사항은 대통령령으로 정한다.

(6) 제 3 항에 따라 대상지역으로 선정된 기초자치단체의 장은 주민 주도 지역관광 활성화사업의 원활 한 추진과 진흥을 위하여 전문인력에 대한 사무공간 및 집기 제공과 교육 및 연수의 실시, 주민사업체 와의 회의 및 교육 공간의 제공 등 그 활동에 필요한 사항을 지원한다.

(7) 지방자치단체의 장은 제3항의 지역으로 선정되기 전에 해당 지역 내에서 제1항 각 호의 사업을 독자적으로 시행하거나 제 3 항의 지원이 종료된 후 필요한 후속지원을 할 수 있다.

제48조의13(주민 주도 지역관광 활성화사업의 전담조직 등) (1) 문화체육관광부장관 또는 지방자치단체 의 장은 주민 주도 지역관광 활성화사업 추진에 필요한 지원을 하기 위하여 필요한 경우에는 대통령 령 또는 해당 지방자치단체의 조례로 정하는 기관 중에서 그 지원을 전담하는 조직을 지정하여, 그 조직의 운영 등에 필요한 경비를 지원할 수 있으며 다음 각 호의 업무를 관장하게 할 수 있다.

1. 제48조의 12 제 1 항에 따른 주민사업체 지원 전문인력에 대한 역량 강화, 평가, 활동 지원과 관리

2. 주민사업체의 발굴 및 육성

3. 사업화계획의 수립 지원

4. 주민사업체의 창업과 경영개선 및 파일럿 사업 지원

5. 사업에 대한 모니터링, 평가

6. 주민 주도 지역관광 활성화사업 및 주민사업체 홍보·마케팅 등 사업 총괄 운영

(2) 제48조의 12 제 1 항제 4 호에 따른 전문인력은 다음 각 호의 업무를 수행한다.

1. 지역 현장에서 주민사업체의 발굴과 조직화, 창업 및 경영개선 지원까지 사업의 총괄 진행

2. 주민사업체와 주민, 지방자치단체와 주민, 고객과 주민, 주민과 주민 사이에서 중간지원 역할의 수행

3. 지역 관광자원의 조사 및 지역의 주민 주도 지역관광 활성화사업 콘셉트 구상

4. 그 밖에 지역 주민사업체 지원·육성을 위하여 필요한 사업

제48조의14(주민사업체의 등록 및 취소) (1) 이 법에 따른 지원을 받고자 하는 주민사업체는 문화체육관 광부 장관이 정하는 바에 따라 기초지방자치단체의 장에게 등록하여야 한다.

(2) 기초지방자치단체의 장은 주민사업체가 다음 각 호의 어느 하나에 해당하면 등록을 취소하거나 문화체육관광부 장관이 정하는 바에 따라 일정 기간 이 법에 따른 지원을 중단할 수 있다. 다만 제1호 에 해당하면 그 등록을 취소하여야 한다.

1. 거짓이나 그 밖에 부정한 방법으로 주민사업체 선정 및 등록을 한 때

2. 동일한 내용에 대하여 타 사업비와 중복하여 지원받았을 때

3. 주민사업체의 구성이나 운영 형태 등이 제1항에서 정하는 바에 부합하지 않을 때

4. 주민사업체와 관련하여 관광두레사업 등에 직접·간접적 영향을 미치는 민사 또는 형사 사건이 발 생하였을 때 
(3) 기초자치단체의 장은 주민사업체 등록 및 운영현황을 매년 12 월 말까지 문화체육관광부장관과 관할 광역자치단체의 장에게 통지하여야 한다.

제76조를 다음과 같이 한다.

제76조(재정 지원) (1) 문화체육관광부장관은 주민 주도 지역관광 활성화사업 그 밖에 관광과 관련된 사업을 하는 지방자치단체, 관광사업자 단체, 주민 주도 지역관광 활성화 전담기관 및 전문인력, 주민 사업체 또는 관광사업자에게 대통령령으로 정하는 바에 따라 보조금을 지급할 수 있다.

(2) 지방자치단체는 그 관할 구역 안에서 관광에 관한 사업을 하는 관광사업자 단체 또는 관광사업자 에게 조례로 정하는 바에 따라 보조금을 지급할 수 있다.

(3) 국가는 관광진흥개발기금법에 따른 관광진흥개발기금의 재원으로 주민 주도 지역관광 활성화사업 을 실시하는데 필요한 지원을 할 수 있다.

(4) 국가 및 지방자치단체는 「국유재산법」, 「공유재산 및 물품 관리법」, 그 밖의 다른 법령에도 불구하 고 관광지등의 사업시행자에 대하여 국유·공유 재산의 임대료를 대통령령으로 정하는 바에 따라 감면 할 수 있다.

(5) 문화체육관광부장관 또는 지방자치단체의 장은 주민사업체 또는 제 48 조의 13 제 1 항 및 제 2 항의 전담조직과 전문인력에 대하여 국유재산 또는 공유재산을 대통령령으로 정하는 바에 따라 대부하거나 사용 수익하게 할 수 있으며 대부료나 사용료를 경감할 수 있다.

제80조제 3 항에 제 10 호를 다음과 같이 신설한다.

10. 주민 주도 지역관광 활성화사업의 시행 (신설)

$$
\text { 부 칙 }
$$

이 법은 공포 후 1년이 지난 날 부터 시행한다.

\section{라. 고려사항}

- 앞서 고려한 관광두레사업의 체계적·제도적 성장·발전 및 체계적인 주민사업 체 육성·지원과 관련한 사항을 전반적으로 포함함

- 별도 지원 법률(안)에서 고려하였던 조문 가운데 기본계획의 수립, 실태조 사, 관광두레협의회 등은 제외하였고, 지방자치단체의 사업과 교육·홍보, 전문인력 양성 등 일부 중복적인 조문에 대해서는 종합하여 규정함

- 사업의 추진체계, 전담조직 및 전문인력, 주민사업체에 대한 법적 근거를 세 개 조항으로 구성함. 입법 과정에서 필요시 핵심 조문 위주로 간명하게 축약하 고, 세부적인 사항은 하위 법령 등으로 위임하는 것을 고려할 수 있음 
- 관광두레사업이 당초 취지에 맞게 제도적으로 작동될 수 있도록 만드는 핵 심 사항은 법률에 규정하고, 정책 환경과 흐름에 맞춰 효율적으로 추진하도 록 하는 사항은 하위 법령에 규정할 필요가 있음

- 이 밖에 구체적인 사업 운영에 대한 사항은 지침을 정비하여 고시하도록 함

\section{1-2. 관광진흥법 제48조제4항제6호 신설(안)}

\section{가. 조문의 위치}

- 현행「관광진흥법」(이하 “법”) 제 48 조제 4 항에 제6호를 신설하여, 관광객의 유치 및 관광 진흥 등을 위하여 문화체육관광부장관과 지방자치단체의 장이 추진할 수 있는 사업으로 "주민 주도 지역관광 활성화사업"을 명시함17)

- 현행 법 제 48 조제 4 항은 문화체육관광부장관과 지방자치단체의 장이 관광 진흥을 위하여 “관광상품의 개발에 관한 사업(제3호)", "국민의 관광복지 증진에 관한 사업(제4호)" 및 "유휴자원을 활용한 관광자원화 사업(제5호)" 등을 "대통령령으로 정하는 바에 따라" 추진할 수 있다고 규정하고 있음 - 이에 동조 제6호에 “주민 주도 지역관광 활성화 사업”을 명시하여 비단 관 광두레사업 뿐만 아니라 지역 주민이 자발적으로 조직하고 운영하는 자생 적이고 지속가능한 관광 사업을 장려하고, 이에 대한 지방자치단체의 협력 과 지원 기틀을 마련하고자 함

- 관광진흥법 시행령 개정 시, 신설 조문의 위치는 다음과 같음

- 현행 법 시행령 제 41 조의5 및 제 41 조의6은 법 제 47 조의5에 관한 내용을, 그리고 제 41 조의7은 법 제 48 조의2에 관한 내용을 담고 있음

- 따라서 법 제 48 조에 관한 사항은 시행령 제 41 조의7로 신설하는 것이 적절 함. 기존 제 41 조의 7 부터 제 41 조의 13 은 각각 제 41 조의 8 부터 제 41 조의 14 로 이동해야 함

17) 관광두레사업의 고유 특성을 반영하는 명칭으로서, 제 48 조제 4 항제 1 호, 제 2 호, 제 5 호가 각각 "문화, 체육, 레저 및 산업시설 등의 관광자원화사업", “해양관광의 개발사업 및 자연생태의 관광자원화사업”, "유휴자원 을 활용한 관광자원화사업”임을 고려하여, “주민공동체 기반의 관광자원화사업”을 대안으로 고려할 수 있음 


\section{나. 주요 내용}

- 관광진흥법에는 문화체육관광부장관과 지방자치단체의 장이 관광진흥을 위하 여 관광두레사업을 추진할 수 있다는 근거 규정만 포함하고, 동법 시행령에 사업의 지원 근거를 포함함

- 동법 시행령에는 관광두레사업의 추진체계와 지방자치단체의 지원 등에 대한 법적 근거를 포함함

- 관광두레사업의 내용 및 범위, 전담조직, 전문인력 등을 규정함

\section{다. 관광진흥법 및 동법시행령 일부개정(예시 안)}

\section{「관광진흥법 및 동법 시행령 일부개정(예시 안)」}

관광진흥법의 일부를 다음과 같이 개정한다.

제48조제4항에 제6호를 다음과 같이 신설한다.

6. 주민 주도 지역관광 활성화사업 (신설)

관광진흥법 시행령의 일부를 다음과 같이 개정한다.

제 41 조의 7 을 다음과 같이 신설한다. 그리고 현행 제 41 조의 7 부터 제 41 조의 13 은 각각 제 41 조의 8 부터 제41조의 14 로 이동한다.

제41조의7 (주민 주도 지역관광 활성화사업 지원 등) (1) 문화체육관광부장관과 지방자치단체의 장은 법 제48조제 4 항제 6 호에 따라 주민 주도 지역관광 활성화를 위하여 다음 각 호의 사항을 지원할 수 있다.

1. 주민사업체(특정한 지역 주민들의 주체적·자발적·협력적 참여를 바탕으로 문화유적지와 먹을거리, 탐방로, 축제, 숙박시설 등 지역 고유의 자원을 연계·활용함으로써 지역특화 브랜드와 관광 사업 을 창출하기 위하여 해당 주민들이 창업하고 그 운영을 주도하는 지역관광 공동체를 말한다. 이하 같다)의 발굴 및 육성 지원

2. 교육·홍보 및 정보의 제공

3. 시설 및 유휴공간 지원

4. 주민사업체 지원을 위한 전문인력 발굴, 육성, 평가 및 활동비 지원

5. 지역자원 활용 콘텐츠 개발

6. 그 밖에 주민 주도 지역관광 활성화사업 지원·육성을 위하여 필요한 사항

(2) 문화체육관광부장관은 제 1 항의 사업을 효율적으로 실시하기 위하여 해마다 기초지방자치단체 중 에서 사업실시 대상지역을 선정하여 기본 3년 동안 지원을 실시하며, 지원에 따른 실적을 매년 평가 하여 평가 결과에 따라 지원을 차등하거나 종료할 수 있다. 
(3) 문화체육관광부장관은 제2항의 평가 결과를 반영하여 2년의 범위에서 추가적으로 지원할 수 있다.

(4) 제 2 항과 제 3 항에 따른 선정 및 평가 기준과 그 밖에 지원에 관하여 필요한 사항은 문화체육관광부 령으로 정한다.

(5) 지방자치단체의 장은 제 2 항의 지역으로 선정되기 전에 해당 지역 내에서 제 1 항 각 호의 사업을 독자적으로 시행하거나 제 2 항과 제 3 항의 지원이 종료된 후 필요한 후속지원을 할 수 있다.

(6) 문화체육관광부장관과 지방자치단체의 장은 주민 주도 관광사업의 추진에 필요한 지원을 하기 위 하여 필요한 경우에는 문화체육관광부령 또는 해당 지방자치단체의 조례로 정하는 기관 중에서 그 지원을 전담하는 조직을 지정하여, 그 조직의 운영 등에 필요한 경비를 지원할 수 있으며 다음 각 호의 업무를 관장하게 할 수 있다.

1. 제1항에 따른 주민사업체 지원 전문인력에 대한 역량 강화, 평가, 활동 지원과 관리

2. 주민사업체의 발굴 및 육성

3. 사업화계획의 수립 지원

4. 주민사업체의 창업과 경영개선 및 파일럿 사업 지원

5. 사업에 대한 모니터링, 평가

6. 주민 주도 지역관광 활성화사업 및 주민사업체 홍보·마케팅 등 사업 총괄 운영

(7) 제1항에 따른 주민사업체 지원 전문인력은 다음 각 호의 업무를 수행한다.

1. 지역 현장에서 주민사업체의 발굴과 조직화, 창업 및 경영개선 지원까지 사업의 총괄 진행

2. 주민사업체와 주민, 지방자치단체와 주민, 고객과 주민, 주민과 주민 사이에서 중간지원 역할의 수행

3. 지역 관광자원의 조사 및 지역의 주민 주도 지역관광 활성화사업 콘셉트 구상

4. 그 밖에 지역 주민사업체 지원·육성을 위하여 필요한 사업

(8) 기초자치단체의 장은 주민 주도 지역관광 활성화사업의 원활한 추진과 진흥을 위하여 전문인력에 대한 사무공간 및 집기 제공과 교육 및 연수의 실시, 주민사업체와의 회의 및 교육 공간의 제공 등 그 활동에 필요한 사항을 지원한다.

(9) 그 밖에 주민사업체 지원·육성 및 효율적 관리 등에 필요한 사항은 문화체육관광부령으로 정한다

\section{라. 고려사항}

- 관광진흥법에 제6호를 신설하는 안으로서, 1-1에서 제안한 관광진흥법 제 48 조의12부터14를 신설하는 안 보다 소요 기간이 단축되는 등 입법 과정의 편 의성이 높을 수 있음

- 관광두레사업 지원과 관련한 구체적인 근거는 시행령에 포함하였기는 하나, 입법 효과성 측면에서는 1-1과 비슷할 것으로 판단함

- 다만 시행령에 예시로 제안한 해당 조항이 타 조항보다 상대적으로 길어 구성 체계 상 부조화와 불균형의 문제가 제기될 수 있음 


\section{2. 관광진흥법 제 47 조의7을 근거로 동법 시행령에 조항 신설(안)}

\section{가. 조문의 위치}

- 관광진흥법 제 47 조의 7 에 따르면 문화체육관광부 장관은 관광산업의 활성화 를 위하여 “대통령령으로 정하는 바에 따라" "관광 관련 창업 촉진 및 창업자 의 성장·발전 지원(제 2 호)", “지역에 특화된 관광상품 및 서비스 등의 발굴·육 성(제5호)"할 수 있다고 규정하고 있음

- 그러나 문화체육관광부 장관이 위 각호와 같은 사업을 추진하기 위해서는 “대통령령으로 정하는 바에”따라야 하는데「관광진흥법」시행령에는 「관광 진흥법」제 47 조의7에서 위임하고 있는 내용에 관한 조문이 부재함

- 현재「관광진흥법」시행령 제 41 조의 5 및 제 41 조의6은 법 제 47 조의5에서 위 임하고 있는 내용을, 그리고 시행령 제 41 조의7은 법 제 48 조의 2 에서 위임하고 있는 내용을 각각 담고 있음

- 따라서 제 47 조의7에서 위임한 사항에 대해서는 41 조의7에 위치하는 것이 바 람직함. 현재 법 제 47 조의7이 위임하고 있는 내용을 담은 조문은 동법 시행령 제 41 조의 7 이므로, 현 시행령 제 41 조의 7 부터 제 41 조의 13 은 각각 제 41 조의 8 부터 제 41 조의 14 로 이동해야 함

\section{나. 주요 내용}

- 관광진흥법 제 47 조의 7 의 내용이 "관광 관련 창업 촉진 및 창업자의 성장.발 전 지원(제 2 호)", “지역에 특화된 관광상품 및 서비스 등의 발굴·육성(제5호)" 이므로, 주민들이 주도적·협력적으로 지역자원을 활용한 관광사업을 창출하는 관광두레사업의 특성을 고려하여, “주민 주도의 지역특화 주민사업체 육성”에 대한 지원 사항을 규정함

- 관광두레사업의 내용, 전담조직 운영 등에 대한 근거를 규정함. 관광진흥법 제 47 조의 7 은 주체가 문화체육관광부 장관이기 때문에 지방자치단체의 장이 관광두레사업을 추진 및 지원하는 근거를 마련하기 부적합함. 다만 장관의 정 
책 추진에 협력하는 지방자치단체에 대하여 지원을 한다고 규정하여, 해당 지 역의 원활한 지원을 유도하고자 함

\section{다. 관광진흥법 시행령 일부개정(예시 안)}

\section{「관광진흥법 시행령 일부개정(예시 안)」}

제41조의7(주민 주도의 지역특화 주민사업체 육성·지원 등) (1) 문화체육관광부장관은 법 제47조의7제 5 호 에 따라 주민사업체(특정한 지역 주민들의 주체적·자발적-협력적 참여를 바탕으로 문화유적지와 먹을거 리, 탐방로, 축제, 숙박시설 등 지역 고유의 자원을 연계·활용함으로써 지역특화 브랜드와 관광 사업을 창출하기 위하여 해당 주민들이 창업하고 그 운영을 주도하는 지역관광 공동체를 말한다. 이하 같다)의 육성을 위하여 다음 각 호의 행정적·재정적·기술적 지원을 할 수 있다.

1. 주민사업체의 발굴 및 육성 지원

2. 교육 · 홍보 및 정보의 제공

3. 시설 및 유휴공간 지원

4. 주민사업체 지원을 위한 전문인력 선정 및 육성, 평가, 활동비 지원

5. 그 밖에 주민사업체의 활성화 등을 위하여 필요한 사항

(2) 문화체육관광부장관은 주민사업체 육성·지원을 위하여 필요한 경우에는 그 지원을 전담하는 조직을 지정할 수 있으며, 그 조직의 운영 등에 필요한 경비를 지원할 수 있다.

(3) 문화체육관광부장관은 제 1 항에 따른 지원과 관련하여 필요한 세부 사항을 정하여 고시할 수 있다.

(4) 문화체육관광부장관은 제 1 항 각 호의 사업을 추진하는 지방자치단체의 장에 대하여 필요한 지원을 할 수 있다.

\section{라. 고려사항}

- 관광진흥법 시행령에 관광두레사업의 근거를 포함하고, 구체적인 사업 운영에 대한 사항은 지침을 정비하여 고시하도록 함

- 본 대안은 입법 과정이 상대적으로 용이한 장점이 있으나, 현재 관광진흥법 제 47 조의7 제 2 항과 제5항에서 대통령령으로 위임했다고 보기에 불명확한 부 분이 있음. 위임근거를 명확히 하기 위해 관광진흥법 제 47 조의7의 개정 필요 성이 제기될 수 있음

- 또한 입법 효과 측면에서 볼 때, 지방자치단체의 지원과 협력을 유도하고 주민 주도 관광생태계를 조성하는 데 한계가 있음. 관광진흥법 제47조의7에서는 문화체육관광부 장관이 할 수 있는 사업에 대해 규정하고 있기 때문에, 지방자 치단체의 장과의 역할, 지원 등에 대한 내용은 포함하기 어려움 


\section{3. 별도 지원 법률(안)}

\section{가. 구성 체계}

- 일반적인 진흥법 체계를 따라 총 17 개 조항으로 구성함 18$)$

\section{나. 주요 내용}

- 관광두레사업과 주민사업체의 정의를 규정하고, 지역관광의 활성화를 촉진하고 주민 주도 관광생태계를 조성하기 위한 국가 및 지방자치단체의 책무를 포함함

- 관광두레사업의 체계적 추진을 위해 기본계획 수립과 실태조사를 시행하도록 하고, 사업 전담조직과 주민사업체 협의체의 구성에 대한 근거를 포함함

- 관광두레사업의 범위를 비롯해 대상지역의 선정 및 평가, 지방자치단체의 사 업 등 추진 체계를 규정함

- 주민사업체의 효율적 관리와 지원을 위해 등록 제도를 포함함

- 관광두레사업에 대한 재정 지원과 주민사업체 또는 전담조직과 주민사업체 협 의체에 대한 국·공유재산의 대부 등을 규정함

\section{다. 관광두레 진흥을 위한 지원 법률(예시 안)}

\section{「관광두레 진흥을 위한 지원 법률(예시 안)」}

제1조(목적) 이 법은 국가 또는 지방자치단체가 주민들이 주도적·협력적으로 지역 고유 자원을 연계·활 용하여 관광 사업을 창업 및 경영개선 하는 데 필요한 사항을 정함으로써 지역관광 활성화와 주민들 의 경제적 이익 보장, 공동체 의식 향상 등 지속가능한 관광 발전을 실현하는 데 목적이 있다.

제2조(정의) (1) 이 법에서 사용하는 용어의 뜻은 다음과 같다.

1. “관광두레사업” 이란 주민의 자발적 참여와 지역자원의 연계·활용을 통한 새로운 방식의 지역관광 발전 모델을 조성하기 위하여 문화체육관광부장관 또는 지방자치단체의 장이 실시하는 제 9 조 각 호의 사업을 말한다.

18) 별도 지원 법률(안)의 구성 체계와 각 조문의 입법 취지 등에 대해서는 제4장 제2절에서 다룸 


\section{「관광두레 진흥을 위한 지원 법률(예시 안)」}

2. "주민사업체”란 특정한 지역 주민들의 주체적·자발적·협력적 참여를 바탕으로 문화유적지와 먹을 거리, 탐방로, 축제, 숙박시설 등 지역 고유의 자원을 연계·활용함으로써 지역특화 브랜드와 관광 사업을 창출하기 위하여 해당 주민들이 창업하고 그 운영을 주도하는 지역관광 공동체를 말한다. (2) 제1항에 규정된 것 외의 용어에 관하여는 이 법에서 특별히 정하는 경우를 제외하고는 「관광진흥 법」 제2조에 따른 용어의 정의에 따른다.

제3조(국가 및 지방자치단체의 책무) (1) 국가는 관광두레사업의 지속적·체계적 추진을 위하여 필요한 행·재정적 지원을 실시할 책무를 진다.

(2) 지방자치단체는 관광두레사업이 지역관광의 활성화를 촉진하고 주민 주도 관광생태계를 조성할 수 있도록 해당 지역 내 주민사업체에 대하여 필요한 행·재정적 지원을 할 책무를 진다.

제4조(다른 법률과의 관계) 관광두레사업에 관하여 이 법에서 정한 사항에 대하여는 다른 법률에 우선 하여 이 법을 적용한다.

제5조(관광두레 기본계획 등의 수립) (1) 문화체육관광부장관은 제1조의 목적을 달성하기 위하여 제9조 제1항 각 호의 사항이 포함된 관광두레사업 기본계획(이하 "기본계획" 이라 한다)을 필요시 관계 중앙 행정기관의 장과 협의하고 지방자치단체의 의견을 들어 5 년 마다 수립하고 이를 지방자치단체의 장에 게 송부하여야 한다.

(2) 지방자치단체의 장은 기본계획의 범위에서 해당 지역에서의 관광두레사업 추진에 필요한 사항에 대하여 해마다 관광두레사업 시행계획(이하 “시행계획”이라 한다)을 수립하고 이를 문화체육관광부장 관에게 제출하여야 한다.

(3) 기본계획 및 시행계획의 수립절차 등에 필요한 사항은 대통령령으로 정한다.

제6조(실태조사) (1) 문화체육관광부장관은 기본계획과 시행계획을 효율적으로 수립·추진하기 위하여 관 광두레사업에 대한 실태조사를 할 수 있다.

(2) 실태조사의 범위와 방법 등 필요한 사항은 대통령령으로 정한다.

제7조(전담조직) (1) 문화체육관광부장관 또는 지방자치단체의 장은 관광두레사업 지원을 위하여 필요한 경우에는 대통령령 또는 해당 지방자치단체의 조례로 정하는 기관 중에서 그 지원을 전담하는 조직을 지정할 수 있으며, 그 조직의 운영 등에 필요한 경비를 지원할 수 있다.

(2) 제1항의 전담조직에 대한 필요한 사항은 대통령령으로 정한다.

제8조(주민사업체 협의체의 구성) (1) 주민사업체는 관광두레사업의 효율적 추진과 상호 부조 등을 위하 여 협의체를 구성할 수 있다.

(2) 제 1 항의 협의체의 구성, 운영 및 지원에 관하여 필요한 사항은 대통령령으로 정한다.

제9조(관광두레사업의 범위 등) (1) 문화체육관광부장관 또는 지방자치단체의 장은 지역관광의 활성화를 촉진하고 주민 주도 관광생태계를 조성할 수 있도록 각 호의 사항을 지원할 수 있다.

1. 주민사업체 발굴 및 육성 지원

2. 교육·홍보 및 정보의 제공

3. 시설 및 유휴공간 지원 


\section{「관광두레 진흥을 위한 지원 법률(예시 안)」}

4. 주민사업체 지원을 위한 전문인력 육성 및 활동비 지원

5. 지역자원 활용 콘텐츠 개발

6. 그 밖에 관광두레사업 지원·육성을 위하여 필요한 사항

(2) 문화체육관광부장관 또는 광역 및 기초지방자치단체의 장은 제 1 항의 지원을 함에 있어 상호 간의 역할 배분에 관하여는 대통령령으로 정한다.

제10조(사업 대상지역 선정 및 평가 등) (1) 문화체육관광부장관은 제8조의 사업을 효율적으로 실시하기 위하여 해마다 기초지방자치단체 중에서 사업실시 대상지역을 선정하여 3년 동안 지원을 실시하며, 지원에 따른 실적을 매년 평가하여 평가 결과에 따라 지원을 차등하거나 종료할 수 있다.

(2) 문화체육관광부장관은 제1항의 평가 결과를 반영하여 2년의 범위에서 추가적으로 지원할 수 있다.

(3) 제1항에 따른 선정 및 평가 기준과 그 밖에 지원에 관하여 필요한 사항은 대통령령으로 정한다.

제11조(지방자치단체의 사업) 지방자치단체의 장은 제 10 조제 1 항의 대상 지역으로 선정되기 전에 해당 지역 내에서 제9조제1항 각 호의 사업을 독자적으로 시행하거나 제10조제2항의 지원이 종료된 이후 필요한 사항을 조례로 정하는 바에 따라 지원할 수 있다.

제48조의14(주민사업체의 등록 및 취소) (1) 이 법에 따른 지원을 받고자 하는 주민사업체는 문화체육관 광부 장관이 정하는 바에 따라 기초지방자치단체의 장에게 등록하여야 한다.

(2) 기초지방자치단체의 장은 주민사업체가 다음 각 호의 어느 하나에 해당하면 등록을 취소하거나 문화체육관광부 장관이 정하는 바에 따라 일정 기간 이 법에 따른 지원을 중단할 수 있다. 다만 제1호 에 해당하면 그 등록을 취소하여야 한다.

1. 거짓이나 그 밖에 부정한 방법으로 주민사업체 선정 및 등록을 한 때

2. 동일한 내용에 대하여 타 사업비와 중복하여 지원받았을 때

3. 주민사업체의 구성이나 운영 형태 등이 제 1 항에서 정하는 바에 부합하지 않을 때

4. 주민사업체와 관련하여 관광두레사업 등에 직접·간접적 영향을 미치는 민사 또는 형사 사건이 발 생하였을 때

(3) 기초자치단체의 장은 주민사업체 등록 및 운영현황을 매년 12 월 말까지 문화체육관광부장관과 관할 광역자치단체의 장에게 통지하여야 한다.

제13조(재정 지원) (1) 국가는 지방자치단체가 관광두레사업을 실시하는 데 필요한 재원을 보조금으로 지원할 수 있다.

(2) 국가는 관광진흥개발기금법에 따른 관광진흥개발기금의 재원으로 관광두레사업을 실시하는 데 필 요한 지원을 할 수 있다.

제 14 조(관광두레 관련 교육·홍보 및 정보의 제공) 문화체육관광부장관 또는 지방자치단체의 장은 관광 두레사업의 시행과 주민사업체에 대한 지원을 위하여 대통령령으로 정하는 바에 따라 교육, 홍보를 실시하거나 관련 정보를 제공할 수 있다.

제 15 조(국·공유재산의 대부 등) 문화체육관광부장관 또는 지방자치단체의 장은 주민사업체 또는 제7조 의 전담조직과 제8조의 주민사업체 협의체에 대하여 국유재산 또는 공유재산을 대통령령으로 정하는 바에 따라 대부하거나 사용 수익하게 할 수 있으며 대부료나 사용료를 경감할 수 있다. 


\section{「관광두레 진흥을 위한 지원 법률(예시 안)」}

제16조(관광두레 육성·지원을 위한 전문인력 양성) 문화체육관광부장관 또는 지방자치단체의 장은 관광 두레 지원·육성을 위하여 대통령령으로 정하는 바에 따라 전문인력을 발굴·양성 및 평가하고 그 활동 을 지원할 수 있다.

제17조(권한의 위탁) 문화체육관광부장관 또는 지방자치단체의 장은 제8조제1항 각호의 지원 업무에 관한 권한의 전부 또는 일부를 대통령령으로 정하는 바에 따라 제6조의 전담조직에 위탁할 수 있다.

\section{라. 고려사항}

- 관광두레사업을 위한 독립 법률로서, 본 연구 과정에서 제기한 관광두레 법제 화 필요성을 충분히 반영함

- 다만 독립 법률을 제정하는 것은 입법 추진 과정에서 어려움이 많음. 특히 유 사 법률과의 차별성, 입법 비용을 상쇄할 정도의 필요성 등을 확보하여 입법 필요성을 부각시키는 데 한계가 있음

- 그럼에도 불구하고 지속가능한 관광 발전을 위해서는 주민 주도의 관광사업 육성이 무엇보다 중요하며, 주민 주도형 정책 추진은 시대적 흐름이기 때문에 중장기적으로 “관광두레 진흥을 위한 지원 법률” 제정을 검토할 필요가 있음

- 기존 지역관광 정책의 문제를 극복하고 지역관광 생태계 혁신을 위해 관광 두레와 같은 주민 주도형 관광콘텐츠 육성 사업이 체계적으로 지역에 내재 화되어야 함 

관광두레 법제화 방안 연구

제5장

결론 및 제언 



\section{제1절 결론}

\section{1. 연구 결과 요약}

- 관광두레사업은 2013년부터 문화체육관광부의 정책 사업으로 추진되어 왔으 며, 주민 주도형 관광 사업을 활성화함으로써 주민들이 일자리와 소득 등 지역 관광 활성화로 인한 실질적 혜택을 받을 수 있도록 함

- 관광두레사업은 주민공동체가 지역자원을 활용해 주체적-자발적·협력적으로 관광사업체를 창업 및 경영 개선할 수 있도록 육성하는 새로운 지역관광 활성 화 모델임. 관광두레PD 라는 전문인력을 양성해, 지역 현장에서 주민공동체 발굴부터 주민사업체 창업 및 경영 개선에 이르는 전 과정을 단계별·맞춤형으 로 지원하도록 사업 방식을 설계한 것이 큰 특징이자 기존 정책과의 차별점임

- 2013년부터 2019년까지 480개 주민공동체를 발굴하고, 이 가운데 110 개가 창업 및 경영 개선을 완료해 전국 곳곳에 주민들이 직접 만들고 경영하는 다양 한 지역관광 주민사업체를 창출함. 또한 주민사업체를 통해 일자리를 만들고 지역 내 소득을 올리는 등 지역 경제 활성화 효과를 냄. 그리고 관광두레 $\mathrm{PD}$, 지역주민들의 역량을 강화하여 관광 주체로 육성하고 지역관광 활성화를 위한 인재로 활동할 수 있는 기반을 마련함. 무엇보다 지역주민들의 자발적인 참여 와 협력의 중요성에 대한 인식 변화를 꾀하였으며, 정책 패러다임 변화를 선도 하는 등 성과를 나타냄

- 이러한 성과에도 불구하고 그동안 내부 사업 지침에 의거해 사업을 운영하다 보니, 추진 과정에서 명확한 법적 근거 부재에 따른 한계가 발생함

- 1 차 년도에는 특히 관광두레사업의 원활한 추진 기반이라고 할 수 있는 각 지방자치단체의 관광두레사랑방 지원 약속이 제대로 이행되지 않거나, 지 
방자치단체의 이해 및 관심 부족 등의 문제점이 나타남

- 1 3차년 주민사업체 육성 단계에서는 법적 근거가 부족하다는 이유로 지방 자치단체의 행-재정적 지원과 협력을 유도하는 데 어려움이 있음. 특히 주 민사업체의 창업과 성장에 지방자치단체의 물적 공간 지원이 대단히 필요 함에도 불구하고, 지방자치단체의 유휴공간을 활용해 관광두레 주민사업체 의 창업을 촉진하거나 공공 관광시설을 연계·활용하는 데 애로가 큼 - 4 5차년 및 사후 관리 단계에는 지방자치단체가 예산을 매칭하고, 중간지 원조직을 운영하는 데 어려움이 있음

- 관광두레사업의 법제화 필요성에 대해 관광두레 $\mathrm{PD}$, 지방자치단체 관계자, 지 역주민 등은 높은 공감을 표시함. 특히 지방자치단체의 지원 및 협력, 지역 관 광자원 및 유휴공간 활용, 주민사업체 관리, 주민 주도 관광사업의 확장과 지 속성, 그리고 안정적인 사업 추진을 위해 근거 법령 필요성을 제기함

- 이에 관광두레사업의 안정적·제도적 성장과 발전과 체계적인 주민 주도 관광 사업체 육성·지원 관점에서 법제화를 추진함

- 법제화 대안으로서 관광진흥법 내 조항을 신설하는 안, 관광진흥법 제 47 조의 7 을 근거로 동법 시행령에 조항을 신설하는 안, 별도 법률을 제정하는 안을 제시함. 입법의 편의성을 고려하면 관광진흥법 시행령 내 조문 신설과 관광진 흥법 내 조문 신설이 현실적임. 다만 입법의 효과성 측면에서는 별도 법률을 제정하는 안이 가장 바람직함

- 본 연구에서는 별도 법률을 제정하는 것을 기준으로 조문과 입법 취지를 기술 함. 그리고 관광두레사업의 제도적·체계적 발전 관점에서 핵심 조문을 구별하 여, 이를 토대로 관광진흥법 또는 동법 시행령에 조항을 신설하는 방안에 대해 조문(예시 안)을 구체적으로 제시함. 중간지원조직 운영과 관련한 사항(전담조 직), 관광두레 $\mathrm{PD}$ 양성 및 활동 지원·평가에 관련한 사항(전문인력), 지방자치 단체의 협력 및 주민 주도 관광사업을 육성·지원하는 근거, 주민사업체의 관 리에 관련한 사항(주민사업체 등록 및 취소), 국·공유재산에 대한 특례 등을 포함함 


\section{2. 본 연구의 의의}

- 관광두레사업이 그간 창출해 온 성과를 정리하고, 사업 추진 과정에서 관광두 레PD, 주민사업체, 지방자치단체 담당자 등이 명확한 근거 법 부재로 인해 겪 은 현장의 어려움을 수렴해 법제화 방안을 제시함

- 관광두레사업의 성과와 한계를 토대로 법제화 필요성과 기대효과, 법제화 방안을 제시했다는 데 의의가 있음

- 지속가능한 관광 발전을 위해서는 주민 주도의 관광사업 육성이 무엇보다 중 요하며, 주민 주도형 정책 추진은 시대적 흐름임. 본 연구 결과는 주민 주도 지역관광 활성화 정책의 제도적 추진 기반을 위한 기초자료로서 의의가 있음

- 본 연구에서는 법제화 대안별 입법 과정의 편의성과 입법 결과의 효과성을 검 토하고, 각 대안별 예시(안)를 제시함으로써 별도 법률 제정 및 관광진흥법 일 부개정 추진 과정에서 실체적 활용이 가능함. 다만 입법 상황에 맞춰 조문 구 성과 내용 등에 대해 별도의 검토가 필요함

- 본 연구를 통한 법제화 추진을 시작으로 주민이 주도하는 지역관광 활성화 기 반이 마련되기를 기대함

- 다만 올해는 관광두레사업의 총괄지원기관이 한국문화관광연구원에서 한국관 광공사로 변경된 첫 해로서 사업 추진 체계나 지원 방식 등이 바뀌는 과도기적 상황이라 본 연구에서는 시행규칙이나 지침 단위에서 다뤄야 하는 구체적인 기준이나 요건 등에 대해서는 다루지 않음 


\section{제2절 제언}

- 관광두레 법제화는 법적 근거를 가지고 정부의 예산과 역량을 지원하는 '지 원', '진흥' 성격임. 따라서 지나치게 세부적으로 구체적인 사항을 법령에 규정 하면, 오히려 사업 운영의 유연성과 효율성을 확보하기 어려울 수 있음. 그럼 에도 관광두레사업의 고유 특성과 추진 체계를 안정화하기 위한 법적 근거 등 핵심적인 사항에 대해서는 명확하고 구체적으로 법제화해야 함

- 이런 관점에서 본 연구를 기초로 법적 기반을 마련하고, 세부적인 기준이나 요건 등은 하위법령이나 지침 등에서 다루어야 함. 요컨대 법에 기반 한 명확 한 지침과 지원 기준 등이 마련될 필요가 있음. 또한 본 연구에서 제안한 법령 조문 가운데 '주민사업체 등록 및 취소'와 관련한 사항은 새롭게 제안한 제도 이므로 이에 대해서는 추가적인 논의와 검토가 필요함

- 한편 관광두레사업의 총괄지원기관이 2020년 사업부터 한국관광공사로 변경 되었고, 이로 인해 사업의 추진 체계와 지원 방식 등에서 이전과 차이를 보이 고 있음. 총괄지원기관의 변동에 따라 사업의 추진 체계 등이 바뀌는 것은 바 람직하지 않음. 관광두레사업의 성과를 보다 확장 및 지속가능하게 하되, 체계 적·제도적으로 안정된 시스템을 운영할 수 있는 별도 지원기관의 설립을 검토 할 필요가 있음

- 주민 주도 관광사업을 통한 지속가능한 지역관광 활성화와 일자리 창출, 주민 소득 증대 등은 단발적인 정책으로 이루어지기 어려움. 관광두레사업 법제화 를 토대로 법적 기반을 갖춘 안정적인 정책으로 발전해 갈 수 있도록 중앙정부 의 지속적인 관심과 노력이 유지되어야 함 
- 현행 관광두레사업은 주민 주도 관광사업을 창출하지만, 정책 추진 방식에서 는 하향식 지원체계로 되어 있음. 중앙정부에서 주민 주도 관광사업 이라는 방향성과 마중물을 제시하고, 지방정부와 민간이 자생적으로 관련 사업을 추 진할 수 있도록 관광두레사업의 지속적 성장·발전 기반을 마련해야 함

- 중장기적으로는 가칭, 관광두레 진흥을 위한 지원 법률(또는 주민공동체 기반 의 관광 사업 육성·지원에 관한 법률)을 별도 신설하는 등 법률적 뒷받침이 이루어질 필요가 있음. 또는 지역관광 육성을 위한 제도적 기반으로서 (가칭) 지역관광진흥법을 제정하고 여기에 지역관광 전담조직과 주민사업체 육성 및 지원에 관한 사항을 포함할 수도 있음

- 마지막으로 법제화 연구에서 그치지 않고 실제 법령 정비가 이루어지기 위해 서는 주관부처인 문화체육관광부의 관심과 노력이 무엇보다 중요함 



\section{참고문헌}

- 김성진·박주영(2013), 「주민주도형 관광사업의 사례 연구」, 서울: 한국문화관광연구원.

- 류광훈(2012), 「관광법제 체계 개편방안 연구」, 서울: 한국문화관광연구원.

- 문화체육관광부(2019), 관광진흥기본계획 2020 시행계획.

- 문화체육관광부(2020), 관광두레 발전 방안(내부자료, 2020.7.8. 일자).

- 문화체육관광부(2020), 「2019년 기준 관광 동향에 관한 연차보고서」.

- 문화체육관광부, 한국문화관광연구원(2020), 「관광두레 7년: 2019 관광두레 연간 실적보고서」.

- 박주영·김성진·박미옥·박연수(2013), 「지역관광 경영 시스템 구축 지원 방안: 관광 두레 만들기」, 문화체육관광부.

- 박주영(2020), 관광두레사업 성과와 향후 정책과제, 「한국관광정책」 2020 여름호 No.80. 서울: 한국문화관광연구원.

- 안성시 내부자료(2020), 안성시 관광 진흥 조례 전부개정안(수정중).

- 양승희(2018), “산림청, 국유림 활용해 마을·사회적기업 212개소 육성한다”, 이로 운넷(2018.6.11. 일자) available at https://www.eroun.net/news/articleView. html?idxno=2536.

- 이준호(2015), 「마을기업 육성 관련 법제 분석」, 세종: 한국법제연구원.

- 최인수·김필두·장인성(2019), 「마을기업 육성 지원에 관한 법률안 및 동법 시행령 제정 연구」, 원주: 한국지방행정연구원.

- 행정안전부(2020), 「2020년 마을기업 육성사업 시행지침」.

- 관광두레 홈페이지(https://tourdure.mcst.go.kr/home/homeIndex.do)

- 법제처 국가법령정보센터(https://www.law.go.kr/)

- 정부입법지원센터(https://www.lawmaking.go.kr/lmGde/atnmLm) 



\section{ABSTRACT}

\section{A Study on the Legalization of Tourdure}

Since 2013, the Ministry of Culture, Sports and Tourism has implemented the Tourdure with a view to nurture local entrepreneurs in tourism industry who make use of local resources and help better manage their businesses. Until 2019, a total of 480 local entrepreneurs have been discovered and nurtured due to the gradual expansion of Tourdure. Moreover, 110 out of the 480 local entrepreneurs have grown into fully fledged companies that provide products and services to tourists, creating 850 jobs in local communities. The Tourdure has led to job creation, boosting economy, and enhancement of sense of community and awareness among local residents.

However, because of lack of explicit basis in relevant law, the Tourdure has experienced difficulties in securing support and cooperation from local governments. Therefore, this study examines the current status of the Tourdure and its limitation due to lack of explicit legal foundation, and suggests ways to provide the legal foundation by analyzing similar laws. Legalization is necessary in order to: 1) induce continued cooperation and support from the local governments by encouraging enactment of relevant local ordinances; 2) expand meaningful participation from local residents and experts; 3) provide support to local businesses for efficient management; 4) secure sustainable operation and achievement of the Tourdure and etc.

This study proposes three recommendations to provide legal foundation for Tourdure: first is to have a special law enacted only for Tourdure; second is to enact relevant provisions within the current Tourism Promotion Act; and 
third is to enact relevant provisions within the Enforcement Decree of the Tourism Promotion Act. It also includes a detailed pros \& cons analysis for each in order to provide support for policy decision making. Hopefully, this study would pave the way for the establishment of legal basis for Tourdure which would help promote local tourism. Of all, continued interest and effort of the Ministry of Culture, Sports and Tourism is essential in actualizing the enactment of relevant law.

\section{Keywords}

Tourdure, Legalization, Community Based Tourism, Sustainable Tourism 


\section{집필내역}

연구책임

박주영 한국문화관광연구원 연구위원: 제1장 제 5 장, 연구총괄

공동연구

진보라 한국문화관광연구원 부연구위원: 제3장

\section{관광두레 법제화 방안 연구}

발행인 김대관

발행처 한국문화관광연구원

서울시 강서구 금낭화로 154

전화 02-2669-9800 팩스 02-2669-9880

http://www.kcti.re.kr

인쇄일 2020년 12월 18일

발행일 2020년 12월 18일

인쇄인 (사)한국장애인이워크협회 일자리사업장

IS B N 978-89-6035-848-593300

DOI https://doi.org/10.16937/kcti.rep.2020.e42 


\section{A Study on the Legalization of Tourdure}

\section{口㫦口 \\ . ……}

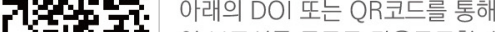

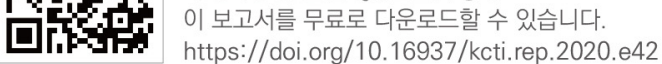

